OPEN ACCESS

Edited by:

Rosario Pignatello,

University of Catania, Italy

Reviewed by:

Mariusz Skwarczynski,

The University of Queensland,

Australia

Lucia Gozzo,

Gaspare Rodolico Hospital, Italy

*Correspondence:

Rudra P. Saha

rudraprasad.saha@

adamasuniversity.ac.in;

rudrasaha@gmail.com

Sang-Soo Lee

123sslee@gmail.com

Chiranjib Chakraborty

drchiraniib@yahoo.com

${ }^{\text {t}}$ These authors have contributed equally to this work

Specialty section: This article was submitted to Experimental Pharmacology and Drug Discovery,

a section of the journal

Frontiers in Pharmacology

Received: 24 May 2020

Accepted: 30 July 2020

Published: 19 August 2020

Citation:

Saha RP, Sharma AR, Singh MK,

Samanta S, Bhakta S, Mandal S,

Bhattacharya M, Lee S-S and Chakraborty C (2020) Repurposing Drugs, Ongoing Vaccine, and New Therapeutic Development Initiatives Against COVID-19.

Front. Pharmacol. 11:1258. doi: 10.3389/fphar.2020.01258

\section{Repurposing Drugs, Ongoing Vaccine, and New Therapeutic Development Initiatives Against COVID-19}

\author{
Rudra P. Saha ${ }^{1 *}$, Ashish Ranjan Sharma ${ }^{2+}$, Manoj K. Singh ${ }^{1}$, Saikat Samanta ${ }^{1}$, \\ Swarnav Bhakta ${ }^{1}$, Snehasish Mandal ${ }^{1}$, Manojit Bhattacharya ${ }^{2}$, Sang-Soo Lee ${ }^{2 *}$ \\ and Chiranjib Chakraborty ${ }^{1,2 *}$ \\ ${ }_{1}^{1}$ Department of Biotechnology, School of Life Science \& Biotechnology, Adamas University, Kolkata, India, 2 Institute for
}

As the COVID-19 is still growing throughout the globe, a thorough investigation into the specific immunopathology of SARS-CoV-2, its interaction with the host immune system and pathogen evasion mechanism may provide a clear picture of how the pathogen can breach the host immune defenses in elderly patients and patients with comorbid conditions. Such studies will also reveal the underlying mechanism of how children and young patients can withstand the disease better. The study of the immune defense mechanisms and the prolonged immune memory from patients population with convalescent plasma may help in designing a suitable vaccine candidate not only for the current outbreak but also for similar outbreaks in the future. The vital drug candidates, which are being tested as potential vaccines or therapeutics against COVID-19, include live attenuated vaccine, inactivated or killed vaccine, subunit vaccine, antibodies, interferon treatment, repurposing existing drugs, and nucleic acid-based vaccines. Several organizations around the world have fast-tracked the development of a COVID19 vaccine, and some drugs already went to phase III of clinical trials. Hence, here, we have tried to take a quick glimpse of the development stages of vaccines or therapeutic approaches to treat this deadly disease.

Keywords: coronavirus, vaccine development, SARS-CoV-2, repurposed drug, antiviral treatment, COVID-19

\section{INTRODUCTION}

Severe Acute Respiratory Syndrome (SARS) caused by SARS Coronavirus (SARS-CoV) initially occurred in China (November 2002) and then quickly spread to 29 countries, resulted in 8,096 cases with 774 fatalities (mortality rate 9.6\%). SARS was officially contained in July 2003, about eight months since its first outbreak (WHO, 2003; Peiris et al., 2004). MERS (Middle East Respiratory Syndrome) caused by MERS-CoV (MERS Coronavirus) has resulted in a similar outbreak by spreading into 26 countries with 2519 infected cases and 866 deaths (mortality rate 34.4\%) after its first report on June 2012 in Saudi Arabia (Assiri et al., 2013; World Health Organization, 2019). The current outbreak of COVID-19 (Coronavirus Disease 2019) caused by SARS-CoV-2, which was first 
reported in the Wuhan (China) on December 2019 (Hubei province), now gradually spilled over 213 countries and territories resulted in over 16.3 million infected cases with and more than 650,000 deaths (4\% mortality rate) as of July 26, 2020 (Wang et al., 2020a). On January 30, 2020, WHO announced the current coronavirus outbreak as a world health emergency, and on March 11, 2020, reclassified it as a pandemic (World Health Organization, 2005; Chakraborty et al., 2020c; WHO, 2020). The virus was initially named Novel Coronavirus 2019 (2019-nCoV), and later it was changed to SARS-CoV-2 (Gorbalenya, 2020). The WHO entitled the disease as COVID-19 on February 11, 2020 (World Health Organization, 2020). The SARS-CoV-2 was found to be infectious as it spreads via respiratory droplets and aerosols when an infected individual comes in contact with a healthy person (Chan et al., 2020b; Liu Y. et al., 2020). The virus incubates for about 2-14 days within humans and subsequently resulted in various mild to severe symptoms like fever, dry cough, dyspnea, severe respiratory issues, pneumonia, etc (Chakraborty et al., 2020a; Chan et al., 2020b; Huang et al., 2020; Lauer et al., 2020; Zu et al., 2020).

Coronaviruses are ssRNA (positive-sense) virus and enveloped with a diameter of 80-120 nm (Sipulwa et al., 2016). This virus (SARS-CoV-2) under the beta-coronavirus genus of the Coronaviridae family comprises four genera- $\alpha-\mathrm{CoV}$, $\beta-\mathrm{CoV}, \gamma-\mathrm{CoV}$, and $\delta-\mathrm{CoV}$ (Chan et al., 2013). Like SARS$\mathrm{CoV}-2, \mathrm{MERS}-\mathrm{CoV}$ and SARS-CoV are also belonged to the genus $\beta$-CoV (Chan et al., 2013). Further, four HCoVs that cause mild symptoms, i.e., common cold, belong to the genera $\alpha$-CoV (HCoV-NL63 and $\mathrm{HCoV}-229 \mathrm{E})$ and $\beta-\mathrm{CoV}(\mathrm{HCoV}-\mathrm{OC} 43$ and HCoV-HKU) (Rabi et al., 2020). The size of the SARS-CoV-2 genome was found to be about $29.9 \mathrm{~kb}$ (GenBank Accession Number: MN908947.3) (Wu F. et al., 2020). Preliminary studies suggested that the genome of SARS-CoV-2 is closer to SARS$\mathrm{CoV}$ than MERS-CoV depending on the percentage similarity, although the highest genome similarity was found with the RaTG13 virus found in bats which indicated a plausible origin of SARS-CoV-2 (bat) (Chakraborty et al., 2020b; Lu et al., 2020; Zhou et al., 2020). Both SARS-CoV-2 and SARS-CoV uses the human ACE2 as a receptor for their entrance in the cell (Ge et al., 2013; Wan et al., 2020; Wrapp et al., 2020).

The cell membrane attached ACE2 converts the vasoconstrictor peptide angiotensin II to angiotensin 1-7 (vasodilator peptide), and it protects the heart and blood vessels (Jiang et al., 2014). ACE2 is found in the heart, lung, kidney, endothelium, etc. and known to

Abbreviations: HCoV, Human Coronavirus; HIV, Human Immunodeficiency Virus; SARS, Severe Acute Respiratory Syndrome; MERS, Middle East Respiratory Syndrome; WHO, World Health Organization; RAS, Renin-Angiotensin System; TLR, Toll-like receptors; STAT, Signal Transducer and Activator of Transcription, ACE2, Angiotensin-converting enzyme 2; AAK1, Adaptor-associated protein kinase 1; JAK-STAT, Janus kinases (JAKs), signal transducer and activator of transcription proteins; ADCC, Antibody-dependent cellular cytotoxicity; RdRp, RNA-dependent RNA polymerase; RSV, Respiratory syncytial virus; PLpro, papain-like protease; PRRs, pattern recognition receptors; ADE, antibodydependent enhancement; ARDS, Acute Respiratory Distress Syndrome; CCL5, C-C motif Chemokine Ligand 5; BCG, Bacillus Calmette-Guérin; RBD, Receptorbinding domain. reduce the adverse effects of other RAS (Renin-Angiotensin System) components by reducing the concentration of angiotensin II and increasing the concentration of angiotensin 17 and regulates the blood pressure in the body. ACE2 also found to express in intestinal epithelial cells where it helps to absorb nutrients from the food particles and was predicted as one of the entry sites that may have been used initially by SARS-CoV-2 upon the consumption of contaminated food from Wuhan seafood market (Hashimoto et al., 2012; Zhang et al., 2020a). Similarly, ACE2 is also found to express on the mucosa of the oral cavity and the epithelial cell of the tongue, making these other entry routes for SARS-CoV-2 (Xu et al., 2020). Interestingly, a small subset of type II alveolar cells (AT2) was found to express the ACE2 receptor and several other genes that positively regulate viral reproduction and transmission, making the lung more susceptible to the virus. The ACE2 expressing cells in the lung triggers an immune response, which may overreact to damage the lung cells by filling up the air sacs with fluid instead of gas, causing pneumonia. Patients with a severely damaged lung can develop acute respiratory distress syndrome (ARDS), where breathing becomes difficult ( $\mathrm{Li}$ et al., 2020). As ACE2 expresses in an array of organs, SARS-CoV-2 can attack several organs, which results in multi-organ failure often observed in patients who died of COVID-19 (Wang T. et al., 2020). Patients with chronic cardiovascular diseases often take drugs that block the angiotensin receptor or inhibit the angiotensinconverting enzyme, which in turn increases the expression of ACE2 receptors in cells. Therefore, COVID-19 patients who regularly take these medications might have an increased hazard of SARS-CoV-2 infection (Diaz, 2020).

Like other coronaviruses, SARS-CoV-2 also consists of two types of protein structural proteins and non-structural. Structural proteins comprise of E (envelope) protein, S (spike) protein, $\mathrm{M}$ (membrane) protein, and $\mathrm{N}$ (nucleocapsid) protein (Wu A. et al., 2020). The spike protein (S) of SARS-CoV-2 is a trimeric class I type of fusion protein that helps the virus to enter host cells (Bosch et al., 2003; Walls et al., 2020). The spike protein has two subunits, S1 (required for receptor recognition) and S2 (required for membrane fusion). The C-terminal RBD (receptor-binding domain) of the first subunit (S1 subunit) of spike protein directly interacts with the ACE2 receptor (Yuan et al., 2020). Upon the fusion of the S protein, which exists in a metastable prefusion state, with the ACE2 receptor, the S protein undergoes a conformational rearrangement. The binding to the ACE2 destabilizes the prefusion trimer, which results in the discharge of the S1 subunit. This allows the transition of the S2 subunit of S protein to a steady postfusion state (de Wilde et al., 2017). A cellular serine protease TMPRSS2 plays a pivotal role in this S protein priming (Hoffmann et al., 2020; Wrapp et al., 2020). The host cell-mediated S protein priming is an essential step for the virus to move into the host cells (Hoffmann et al., 2018). Once inside of the host cell, SARS-CoV-2 follows the typical life cycle of a positive-sense RNA virus as was found with MERS-CoV and SARS-CoV (Figure 1) (Fehr and Perlman, 2015).

According to some mathematical models, the transmission of the disease may quickly rebound if we relax measures like 
lockdown and social distancing (Yamey et al., 2020). In the absence of effective prophylactic treatment, such eruptions may leave the health system overburdened. The absence of a potential drug or vaccine against SARS-CoV-2 has already resulted in a pandemic situation (Wang D. et al., 2020). The designing and development of the COVID-19 vaccine that can be used globally is, therefore, the utmost priority for ending the current pandemic (Prompetchara et al., 2020). It was observed that both SARS-CoV-2 and SARS-CoV use the same mechanism to enter target cells has vital significance for our understanding of the SARS-CoV-2 pathogenesis and transmissibility. To fight this pandemic, various government and private organizations have sped up their development of vaccines and treatment procedures. In this review article, we have discussed the testing of various existing drugs that are now being repurposed and targets against which various vaccine developments are going on for COVID-19.

\section{HOST IMMUNE RESPONSE TO VIRAL INFECTIONS}

Upon viral infection, the host cell initially activates the innate immune response via PRRs (pattern-recognition receptors) that recognizes viral particles (Takeuchi and Akira, 2009). Host cells release a group of signaling proteins called Interferons (IFNs) that play a significant role in host antiviral defense. INFs belong to a group of peptides and proteins called cytokines responsible for transferring signals by binding to the receptors on the surface of

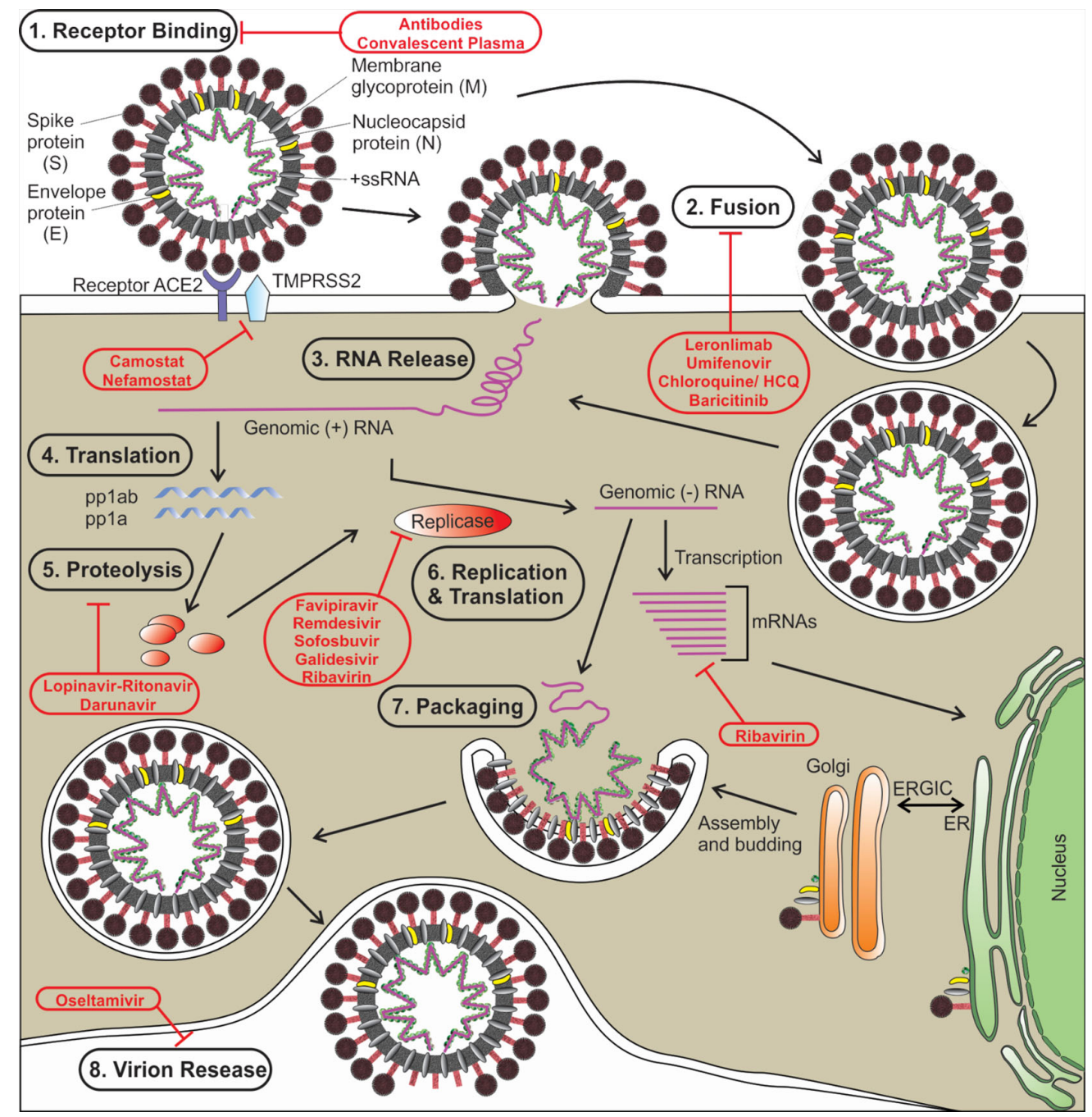

FIGURE 1 | The life cycle of SARS-CoV-2 is shown. Various steps in the life cycle are mentioned-receptor binding of the virus, fusion with the host membrane, viral RNA release, translation of viral RNA, proteolysis of the proproteins, replication and translation, packaging of viral particles, and virion release. Possible targets of various antiviral drugs that are being repurposed/investigated for COVID-19 are indicated. S, spike protein; E, envelope protein; M, membrane protein; $\mathrm{N}$, nucleocapsid protein; $\mathrm{HCQ}$, hydroxychloroquine, ER, endoplasmic reticulum; ERGIC, ER-Golgi intermediate compartment. 
appropriate immune cells for triggering host immune response against pathogens. INFs are triggered by the activation of host PRRs. Four types of PRRs are known-TLRs, RLRs, NLRs, and CLRs although during viral infection mainly three types of PRRs are activated-RLRs, TLRs, and NLRs (González-Navajas et al., 2012; Fehr and Perlman, 2015; Nan et al., 2018; Zhang et al., 2020b). PRRs recognize several viral components including DNA, ssRNA, dsRNA, RNA with 5'-triphosphate ends, and proteins. Detection of viral particles by PRRs activates signaling pathways that release type I INFs, different types of cytokines such as proinflammatory cytokines (primarily IL-1, IL- 6 , TNF- $\alpha$ ), chemokines, and costimulatory molecules like CD40, CD80, and CD86 that results in inflammation and subsequent engagement of innate and acquired immune cells to eliminate viral infection (González-Navajas et al., 2012; Khan et al., 2012; Nan et al., 2018).

Three types of INFs have been characterized till now-type I IFNs (mainly IFN- $\alpha / \beta$ ), type II IFNs (IFN- $\gamma$ ), and type III (INF- $\lambda$ ) (Stanifer et al., 2019). INFs- $\alpha / \beta$ is secreted by all viral-infected cells including pDCs (plasmacytoid dendritic cells) which is a vital cell type for INF- $\alpha$ secretion during viral infection. IFN- $\gamma$, secreted by NK (natural killer) cells and immune cell-like T cells, plays a vital role in host adaptive and innate immunity. It also regulates the expression of several genes that are affected by type I IFNs. INF- $\lambda$ is mainly secreted by epithelial cells in response to the viral infection at mucosal sites (Zanoni et al., 2017). INFs protect host cells by activating signaling pathways, mainly the JAK/ STAT pathway (Schindler et al., 1992; Darnell et al., 1994), which subsequently trigger the expression of ISGs (IFNstimulated genes) that controls the viral infection (Katze et al., 2002). The activated STAT proteins (STAT1, STAT2, and STAT3) in response to INF stimulation are vital for transferring signals that subsequently activate ISGs (Levy and Darnell, 2002; Tsai et al., 2019). Type I INFs induced during innate immune response also upregulate several ISGs whose expression restricts viral replication (Kane et al., 2016).

Activation of the innate immune cells is critical for setting up adaptive immune responses during the re-infection by the same virus. Activation of adaptive immunity takes a few days to weeks to become established. APCs (antigen-presenting cells; e.g., dendritic cells, B cells and macrophages), that live at the site of viral infection, binds to viral particles (antigens) and present them on major histocompatibility complex (MHC) class II to be recognized by the $\mathrm{T}$ cell receptor on $\mathrm{CD} 4^{+} \mathrm{T}$ cells in presence of co-stimulatory molecules (Rosendahl Huber et al., 2014). The activated $\mathrm{CD}^{+} \mathrm{T}$ cells release a wide range of cytokines and chemokines that helps to differentiate $\mathrm{CD} 4^{+} \mathrm{T}$ cells into several cell subtypes, mainly $\mathrm{T}$ helper cells (such as Th1, Th2, Tfh, etc.) as well as regulatory $\mathrm{T}$ cells (Treg). Th1 and Th2 cells release several cytokines (Th1-INF- $\gamma$, Th2- IL-4, IL-13, IL-5, etc.) to trigger $\mathrm{B}$ cell differentiation and activate macrophages (Rosendahl Huber et al., 2014). T follicular helper cells (Tfhs) also helps to activate $\mathrm{B}$ cells to produce specific antibodies against foreign pathogens (Crotty, 2014). Treg cells do several regulatory functions, especially controlling immunopathology (Crotty, 2014). Activated $\mathrm{CD}^{+} \mathrm{T}$ cells by its interaction with the APCs through CD40-CD40L upregulate expression of CD80/CD86 markers on APCs which interacts with the CD28 on the CD8 ${ }^{+}$ T cells. The APCs presents viral particles on the MHC class I molecules that bind to the TCRs on the $\mathrm{CD} 8^{+} \mathrm{T}$ cells through the CD80/CD86-CD28 interactions and activate CD ${ }^{+} \mathrm{T}$ cells. The activated cells proliferate and differentiate into CTLs (cytotoxic T lymphocytes) which releases cytotoxic molecules, and activates the production of cytokines (e.g., TNF- $\alpha$, IL-2, IFN- $\gamma$, etc.) that promotes apoptosis of virally infected cells (Crotty, 2014).

Both innate and adaptive immunity (humoral and cellmediated) are equally important to control viral infections. Innate immunity mounts host defenses to control viral infection at the early phases by releasing proinflammatory molecules and also activates adaptive immunity by upregulating co-stimulatory molecules. In adaptive immunity, B cells (humoral immunity) and $\mathrm{T}$ cells (cell-mediated immunity) are activated that prevent further viral infections. Immunoglobulins (IgG, IgM, and $\operatorname{IgA}$ ) produced by activated $\mathrm{B}$ lymphocytes bind to viruses to block viral spread and also eliminate virus-infected cells via ADCC (antibody-dependent cytotoxic cells) or complement-mediated pathways. CTLs differentiated from activated $\mathrm{CD}^{+} \mathrm{T}$ cells kill the virus-infected cells by releasing cytotoxic cytokines that trigger apoptosis of the target cells. Some of these immune cells (T cells and B cells) are converted into memory cells that prevent further infections and provide long-term immunity (Klimpel, 1996).

SARS-CoV and other coronaviruses are sensitive to IFN- $\alpha / \beta$. Some of these viruses are also very pathogenic. It might be attributed to their ability to modulate an effective host immune response. The nucleocapsid protein of SARS-CoV can evade host interferon responses (Spiegel et al., 2005; Kopecky-Bromberg et al., 2007; Lu et al., 2011). It was reported that EV71 (Liu et al., 2014) and Ebola virus infections can downregulate the JAK-STAT pathway mediated by type-I IFNs, and promote viral replication and proliferation within the host (Okumura et al., 2010). Several antibodies, for example, MCA1, CSCC5, CDC-C2, CDC-A10, CDC-A2, MERS-GD27, etc., isolated from recovered MERS-CoVinfected patients have been found useful in controlling the disease (Chen et al., 2017; Niu et al., 2018a; Niu et al., 2018b). Recognition mechanisms involving the surface proteins of virus and the receptors of host are vital for an understanding of the crossspecies transmission and host tropism to establish animal models for effective vaccine development (Ahn et al., 2020).

Some COVID-19 patients with severe symptoms experience a sudden surge of cytokines in the body, released by the immune cells in response to the viral infection, commonly referred to as 'cytokine storm' (Huang et al., 2020). The excessive release of the cytokines or cytokine release syndrome (CRS) is a major determinant in inducing ARDS in COVID-19 patients. The excessive secretion of proinflammatory cytokines (e.g., IL-6, IL-1, TNF- $\alpha$, etc.) with the help of the innate immune system within the body leads to several lung complications like pneumonitis and ARDS which can cause multi-organ failure and death (Nicholls et al., 2003; Mahallawi et al., 2018; Ragab et al., 2020). Among various proinflammatory cytokines, IL-6 plays a major role in inducing ARDS as an increase in the concentration of IL-6 in the plasma was found to be linked with ARDS in COVID-19 patients (Ragab et al., 2020). Association of 
IL-6 to mIL-6R (membrane-bound IL-6 receptor) and gp130 activates the JAK-STAT3 pathway which contributes toward CRS. Besides, at high concentrations, IL-6 binds to sIL-6R (soluble form of IL-6 receptor) and gp130, and activates JAKSTAT3 pathway in cells that do not express mIL-6R which again induces cytokine storm by releasing several cytokines and chemokines (e.g., VEGF, IL-6, MCP-1/CCL2, IL-8, etc.), and by reducing E-cadherin production that leads to ARDS (Magro, 2020; Ragab et al., 2020). Therefore, preventing the occurrence of cytokine storm by drugs that inhibits the release of cytokines may help in alleviating severe COVID-19 symptoms.

\section{VIRAL AND HOST PROTEIN TARGETS}

\section{Vaccines}

SARS-CoV-2 expresses four structural proteins, $\mathrm{N}$ (nucleocapsid), E (envelope), S (spike) protein, and $M$ (membrane) similar to SARS-CoV. These proteins are potential antigens to induce nAbs (neutralizing antibodies) and provide protective functions (Bhattacharya et al., 2020a; Chan et al., 2020a; Shang et al., 2020). So, the finding of a protein that has the dominant neutralizing epitopes should be the first step of the investigation. Before this identification, the inactivated virus can also be used as a firstgeneration vaccine because it is probably easier to generate than the whole-killed virus particles. Whole-cell killed or live-attenuated vaccines represent all the antigens present in a pathogen like proteins, nucleic acids, polysaccharides, lipids, and some other components capable of inducing a potent immune response (Sharma et al., 2011). Several studies have shown that SARS-CoV inactivated through an agent such as formaldehyde, $\beta$ propiolactone and UV light can also instigate virus-neutralizing antibodies in immunized animals (He et al., 2004; Xiong et al., 2004; Jiang et al., 2005; Qu et al., 2005; Te-hui et al., 2005). So in principle, inactivated SARS-CoV-2-based vaccines can also be used. However, upon identification of the neutralizing epitopes, the vaccines that are made based on fragments containing neutralizing epitopes should be used, as they are safer and more effective than the inactivated virus vaccine. Several organizations are using viral deoptimization techniques to synthesize more effective vaccines such as live-attenuated vaccines (Zhang J. et al., 2020). Though, attenuated vaccine mimics the natural course of infection to stimulate the toll-like receptors e.g. (TLR-3, TLR-4, TLR-7, TLR8, and TLR-9) and provide long-term immunity, ensuring low or no pathogenicity is always a major concern (Chakraborty et al., 2020d). Also, killed vaccines show difficulty in maintaining consistency in quality (Chen W. H. et al., 2020).

Most of the subunit vaccines against coronaviruses depend on mounting immune responses against the spike protein by preventing its binding to the host ACE2 receptor (Jiang et al., 2012). One way to block access to the entry receptor, i.e., human ACE2 receptor is to use the spike protein $\mathrm{RBD}$ (receptor-binding domain) of SARS-CoV-2 that has been shown to attach to the ACE2 receptor (Lan et al., 2020). Spike protein's RBD from SARS-CoV has been shown to block the virus from accessing the ACE2 receptor in cell culture (Wong et al., 2004). Besides, the
RBDs of spike proteins in both SARS-CoV-2 and SARS-CoV were found to interact similarly with the ACE2 receptor (Lan et al., 2020). Other researchers have proposed that the RBDs on the spike proteins of other coronaviruses like $\mathrm{MHV}$ (mouse hepatitis virus), TGEV (transmissible gastroenteritis virus), $\mathrm{HCoV}-229 \mathrm{E}$, SARS-CoV, etc. contain key antigenic determinants that can induce production of neutralizing antibodies (Godet et al., 1994; Kubo et al., 1994; Bonavia et al., 2003; He et al., 2004). As spike proteins of coronaviruses are the most important antigenic determinants known to trigger neutralizing antibodies, spike proteins can be used as antigens for developing vaccines (Saif, 1993; Schmidt et al., 2006; Bhattacharya et al., 2020a; Bhattacharya et al., 2020b). Spike protein RBD sequences are relatively conserved. So, this may possible to find the neutralizing epitopes present into the SARSCoV-2 spike protein for designing and developing of effective, safe vaccine against this virus. How spike protein RBD can activate extremely effective neutralizing antibodies against this virus has been elucidated by the mAbs (monoclonal antibodies) which was isolated from the inactivated virus-immunized human and mice antibody libraries (Sui et al., 2004; He et al., 2005). Thus, the RBD of this virus $S$ protein is not only a functionally important domain for receptor binding of this virus but also a significant neutralization determinant element of SARS-CoV-2. So, the proteins that contain the RBD region or vectors encoding the spike protein $\mathrm{RBD}$ can be utilized for developing a highly effective vaccine candidate (Table 1). Therefore, the RBD alone could block access to ACE2 for SARS-CoV-2. Alternatively, single-domain antibodies (sdAbs) or nanobodies based on the RBD can also block the ACE2 receptor effectively (ArbabiGhahroudi, 2017). Researchers are developing virus-like nanoparticles based on the expression of recombinant spike protein, which can act as a potent immunogen. Others have developed subunit vaccines consisting of the RBD from SARSCoV S protein (Chen W. H. et al., 2020). However, certain limitations of subunit vaccines exist, for example, the requirement of multiple booster shots and suitable adjuvants (Shang et al., 2020).

During the vaccine candidate development against SARS$\mathrm{CoV}-2$, one may have to consider the possibility of antibodydependent enhancement (ADE) triggering in vaccinated individuals where instead of mounting protection against the virus infection the virus-bound antibody bind to the host cell receptors to facilitate the cellular entry of the virus. Activation of $\mathrm{ADE}$ has been observed in vaccines against several diseases, e.g., Ebola, HIV, Dengue, feline coronavirus, etc (Takada and Kawaoka, 2003; Halstead, 2017; Takano et al., 2019). Human and rodent antibodies produced against the SARS-CoV S protein also shown to induce ADE in vitro (Liu et al., 2019). However, ADE was not observed in several pre-clinical studies done in rhesus monkeys using a SARS-CoV vaccine (Luo et al., 2018). Besides, in a pre-clinical study using an inactivated SARS-CoV-2 vaccine did not show any evidence of ADE (Gao Q. et al., 2020).

\section{Therapeutics}

SARS-CoV-2 does not use receptors that are utilized by other coronaviruses, for example, APN (aminopeptidase N; used by 
TABLE 1 | Ongoing vaccine development initiatives against COVID-19 by different organizations that are at different phases of clinical and preclinical trials (updated on July 25, 2020).

\begin{tabular}{|c|c|c|c|c|}
\hline No. & Clinical/preclinical stage & Vaccine name/type & Remark & Organization/Company \\
\hline 1 & Phase IV & Oral polio vaccine & $\begin{array}{l}\text { mixture of live attenuated } \\
\text { poliovirus strains }\end{array}$ & Bandim Health Project, Denmark \\
\hline 2 & Phase IV & BCG vaccine & live attenuated bacteria & Merck \& Co. Inc., USA \\
\hline 3 & Phase III & mRNA-1273 & LNP-encapsulated mRNA & Moderna Therapeutics Inc., USA \\
\hline 4 & Phase III & Viral vaccine & Inactivated vaccine & $\begin{array}{l}\text { Sinopharm, China; Wuhan Institute of Biological } \\
\text { Products, China }\end{array}$ \\
\hline 5 & Phase III & Coronavac & Inactivated + alum & $\begin{array}{l}\text { Sinovac Biotech Ltd., China; Dynavax } \\
\text { Technologies, USA; Instituto Butantan, Brazil; PT } \\
\text { Bio Farma, Indonesia }\end{array}$ \\
\hline 6 & Phase II & Ad5-nCoV & $\begin{array}{l}\text { nonreplicating viral vector } \\
\text { (Adenovirus Type } 5 \text { Vector) }\end{array}$ & $\begin{array}{l}\text { Cansino Biologics Inc., China; The Beijing Institute } \\
\text { of Biotechnology of the } \\
\text { Academy of Military Medical Sciences, China }\end{array}$ \\
\hline 7 & Phase I/II & AV-COVID-19 & $\begin{array}{l}\text { autologous dendritic cells loaded } \\
\text { with antigens from SARS-CoV-2 }\end{array}$ & Aivita Biomedical Inc., USA \\
\hline 8 & Phase I/II & AG0301-COVID19 & DNA plasmid vaccine & $\begin{array}{l}\text { Anges Inc., Japan; Osaka University, Japan; } \\
\text { Takara Bio Inc., USA; Japan Agency } \\
\text { for Medical Research and Development, Japan }\end{array}$ \\
\hline 9 & Phase I/II & $\begin{array}{l}\text { AZD-1222 (formerly } \\
\text { ChAdOx1 nCoV-19) }\end{array}$ & nonreplicating viral vector-based & $\begin{array}{l}\text { Astrazeneca, UK; The Jenner Institute, UK; } \\
\text { University of Oxford, UK; Oxford Biomedicaplc, } \\
\text { UK; Vaccines Manufacturing and Innovation } \\
\text { Centre, UK; Pall Life Sciences, USA; Cobra } \\
\text { Biologics, UK; Halix BV, Netherlands; Emergent } \\
\text { Biosolutions Inc., USA; Catalent Inc., USA }\end{array}$ \\
\hline 10 & Phase $|/| \mid$ & Covaxin & inactivated whole-virion vaccine & Bharat Biotech International Ltd., India \\
\hline 11 & Phase I/II & BNT-162 & RNA vaccine; 3 LNP-mRNAs & $\begin{array}{l}\text { Biontech AG, Germany; Shanghai Fosun } \\
\text { Pharmaceutical Co. Ltd., China; Pfizer Inc., USA }\end{array}$ \\
\hline 12 & Phase I/II & SARS-CoV-2 vaccine & Inactivated vaccine & $\begin{array}{l}\text { Chinese Academy of Medical Science, China; } \\
\text { West China Second University Hospital, China; } \\
\text { Yunnan Center for Disease Control and } \\
\text { Prevention, China }\end{array}$ \\
\hline 13 & Phase $\mid / I I$ & Gam-COVID-Vac & $\begin{array}{l}\text { nonreplicating viral vector } \\
\text { (Adeno-based) }\end{array}$ & $\begin{array}{l}\text { Gamaleya Research Institute of Epidemiology and } \\
\text { Microbiology, Russia; Health Ministry of the } \\
\text { Russian Federation, Russia; Acellena Contract } \\
\text { Drug Research \& Development }\end{array}$ \\
\hline 14 & Phase $1 / 11$ & GX-19 & DNA Vaccine & $\begin{array}{l}\text { Genexine Inc., South Korea; PT Kalbe FarmaTbk, } \\
\text { Indonesia }\end{array}$ \\
\hline 15 & Phase $1 / 11$ & V-SARS & $\begin{array}{l}\text { made from heat-inactivated } \\
\text { plasma from donors with COVID- } \\
19\end{array}$ & Immunitor LLC, Canada \\
\hline 16 & Phase $\mid / \|$ & COVAC1 & RNA vaccine (saRNA) & Imperial College, UK \\
\hline 17 & Phase $1 / 11$ & INO-4800 & DNA plasmid vaccine & $\begin{array}{l}\text { Inovio Pharmaceuticals Inc., USA; Beijing } \\
\text { Advaccine Biotechnology Co. Ltd., China; } \\
\text { Geneone Life Science Inc., South Korea; Ology } \\
\text { Bioservices Inc., USA; International Vaccine } \\
\text { Institute, South Korea }\end{array}$ \\
\hline 18 & Phase $1 / I 1$ & KBP-COVID-19 vaccine & $\begin{array}{l}\text { protein subunit vaccine; RBD- } \\
\text { based }\end{array}$ & $\begin{array}{l}\text { Kentucky Bioprocessing (KBP), USA; U.S. biotech } \\
\text { subsidiary of British American Tobacco (BAT) }\end{array}$ \\
\hline 19 & Phase I/II & Allostim vaccine & $\begin{array}{l}\text { bioengineered cells to provide } \\
\text { protection from different viral } \\
\text { infections }\end{array}$ & $\begin{array}{l}\text { Mirror Biologics Inc., USA; Immunovative } \\
\text { Therapies Ltd., Israel; Hadassah-Hebrew } \\
\text { University Medical Center, Israel }\end{array}$ \\
\hline 20 & Phase $1 / I 1$ & NVX-CoV2373 & $\begin{array}{l}\text { protein subunit vaccine; full } \\
\text { length recombinant SARS-CoV-2 } \\
\text { glycoprotein nanoparticle vaccine } \\
\text { adjuvanted with Matrix M }\end{array}$ & Novavax Inc., USA \\
\hline 21 & Phase I/II & Adenoviral vector vaccine & $\begin{array}{l}\text { nonreplicating viral vector; } \\
\text { replication defective Simian } \\
\text { Adenovirus (GRAd) encoding } \\
\text { SARS-CoV-2 S }\end{array}$ & $\begin{array}{l}\text { Reithera Srl, Italy; Leukocare AG, Germany; } \\
\text { Univercells SA, Belgium }\end{array}$ \\
\hline 22 & Phase $1 / I 1$ & LV-SMENP-DC & $\begin{array}{l}\text { lentiviral vector system that } \\
\text { express viral proteins and } \\
\text { immune modulatory genes }\end{array}$ & Shenzhen Geno-immune, China \\
\hline
\end{tabular}


TABLE 1 | Continued

\begin{tabular}{|c|c|c|c|c|}
\hline No. & Clinical/preclinical stage & Vaccine name/type & Remark & Organization/Company \\
\hline 23 & Phase $1 / I 1$ & BBIBP-CorV & Inactivated vaccine & $\begin{array}{l}\text { Sinopharm, China; Beijing Institute of Biological } \\
\text { Products Co. Ltd., China; Henan Provincial } \\
\text { Center for Disease Control and Prevention, China }\end{array}$ \\
\hline 24 & Phase l/II & ZyCov-D & plasmid DNA vaccine & Zydus Cadila, India \\
\hline 25 & Phase I & $\begin{array}{l}\text { LUNAR-COV19 (ARCT- } \\
\text { 021) }\end{array}$ & RNA vaccine (mRNA) & $\begin{array}{l}\text { Arcturus Therapeutics Holdings Inc., USA; Duke- } \\
\text { NUS Medical School, Singapore }\end{array}$ \\
\hline 26 & Phase I & SCB-2019 & $\begin{array}{l}\text { protein subunit vaccine; native- } \\
\text { like trimeric subunit spike protein } \\
\text { vaccine }\end{array}$ & $\begin{array}{l}\text { Clover Biopharmaceuticals Inc., China; } \\
\text { Glaxosmithkline plc., UK; Dynavax Technologies } \\
\text { Corp., USA }\end{array}$ \\
\hline 27 & Phase I & DNA vaccine & DNA with electroporation & $\begin{array}{l}\text { Cobra Biologics Ltd., UK; Karolinska Institutet, } \\
\text { Sweden }\end{array}$ \\
\hline 28 & Phase I & CVnCoV & RNA vaccine (mRNA) & Curevac AG, Germany \\
\hline 29 & Phase I & RUTI vaccine & $\begin{array}{l}\text { replicating viral vector; } \\
\text { attenuated influenza expressing } \\
\text { an antigenic portion of the spike } \\
\text { protein }\end{array}$ & Fundacio Institut Germans Trias i Pujol, Spain \\
\hline 30 & Phase I & COVAX-19 & spike protein-based vaccine & $\begin{array}{l}\text { Genecure Biotechnologies, USA; Vaxine, } \\
\text { Australia; Medytox, South Korea }\end{array}$ \\
\hline 31 & Phase I & DPX-COVID-19 & $\begin{array}{l}\text { protein subunit vaccine; peptide } \\
\text { antigens formulated in LNP }\end{array}$ & IMV Inc., Canada; University Laval, Canada \\
\hline 32 & Phase I & IPT-001 & peptide-based vaccine & Intellistem Technologies Inc., Canada \\
\hline 33 & Phase I & $\begin{array}{l}\text { Virus-like particle vaccine; } \\
\text { CoVLP }\end{array}$ & $\begin{array}{l}\text { plant-derived VLP; CpG } 1018 \\
\text { and pandemic adjuvant }\end{array}$ & Medicago Inc., Canada; Glaxosmithkline plc., UK \\
\hline 34 & Phase I & $\begin{array}{l}\text { Adjuvanted recombinant } \\
\text { subunit vaccine }\end{array}$ & $\begin{array}{l}\text { S protein (baculovirus } \\
\text { production) }\end{array}$ & Sanofi SA, France; Glaxosmithkline plc., UK \\
\hline 35 & Phase I & aAPC vaccine & $\begin{array}{l}\text { lentiviral vector system to } \\
\text { express SARS-CoV- } 2 \text { minigenes } \\
\text { engineered based on multiple } \\
\text { viral genes }\end{array}$ & Shenzhen Geno-immune Medical Institute, China \\
\hline 36 & Phase I & bacTRL-Spike & DNA vaccine & Symvivo Corp., Canada \\
\hline 37 & Preclinical & mRNA vaccine & $\begin{array}{l}\text { needle-free injection system to } \\
\text { deliver mRNA }\end{array}$ & Abnova Corp., Taiwan; Pharmajet Inc., USA \\
\hline 38 & Preclinical & SARS-CoV-2 vaccine & $\begin{array}{l}\text { saponin-based adjuvant TQL- } \\
1055 \text { with SARS-CoV-2 antigen }\end{array}$ & $\begin{array}{l}\text { Adjuvance Technologies Inc., USA; National } \\
\text { Institutes of Health, USA }\end{array}$ \\
\hline 39 & Preclinical & MAPS vaccine & $\begin{array}{l}\text { polysaccharide and the protein- } \\
\text { based multiple antigen } \\
\text { presenting system }\end{array}$ & Affinivax Inc., USA \\
\hline 40 & Preclinical & Vaccine & $\begin{array}{l}\text { protein subunit vaccine based on } \\
\text { Spike protein }\end{array}$ & AJ Vaccines, Denmark \\
\hline 41 & Preclinical & COVID-19 vaccine & triple antigen VLP vaccine & $\begin{array}{l}\text { Akers Biosciences Inc., USA; Premas Biotech Pvt } \\
\text { Ltd., India }\end{array}$ \\
\hline 42 & Preclinical & Chimigen vaccine & recombinant protein vaccine & $\begin{array}{l}\text { Akshaya Bio Inc., Canada; Cytovance Biologics, } \\
\text { USA; Shenzhen Hepalink Pharmaceutical Group } \\
\text { Co. Ltd., China }\end{array}$ \\
\hline 43 & Preclinical & AdCOVID & $\begin{array}{l}\text { nonreplicating viral vector; } \\
\text { adenovirus-based NasoVAX } \\
\text { expressing SARS-CoV-2 spike } \\
\text { protein }\end{array}$ & $\begin{array}{l}\text { Altimmune Inc., USA; University of Alabama at } \\
\text { Birmingham, USA }\end{array}$ \\
\hline 44 & Preclinical & COVID-19 vaccine & VLP vaccine & Artes Biotechnology GmbH, Germany \\
\hline 45 & Preclinical & $\begin{array}{l}\text { Recombinant coronavirus } \\
\text { vaccine }\end{array}$ & spike protein-based & $\begin{array}{l}\text { Autonomous University of Mexico (UNAM), } \\
\text { Mexico }\end{array}$ \\
\hline 46 & Preclinical & COVID-19 vaccine & spike protein-based & $\begin{array}{l}\text { Autonomous University of Queretaro (UAQ), } \\
\text { Mexico }\end{array}$ \\
\hline 47 & Preclinical & Vaccine & $\begin{array}{l}\text { protein subunit vaccine; based } \\
\text { on peptides derived from spike } \\
\text { protein }\end{array}$ & Axon Neuroscience SE, Cyprus \\
\hline 48 & Preclinical & Vaccine & $\begin{array}{l}\text { protein subunit vaccine; S1 or } \\
\text { RBD of spike protein }\end{array}$ & $\begin{array}{l}\text { Baylor College of Medicine, USA; New York } \\
\text { Blood Center, USA; Fudan University, China }\end{array}$ \\
\hline 49 & Preclinical & Vaccine & universal dendritic cell vaccine & $\begin{array}{l}\text { Betta Pharmaceuticals Co. Ltd., China; Beijing } \\
\text { Dingcheng Taiyuan Biotechnology, China }\end{array}$ \\
\hline 50 & Preclinical & Vaccine & DNA vaccine & Bionet Asia, Thailand \\
\hline
\end{tabular}


TABLE 1 | Continued

\begin{tabular}{|c|c|c|c|c|}
\hline No. & Clinical/preclinical stage & Vaccine name/type & Remark & Organization/Company \\
\hline 51 & Preclinical & SARS-CoV-2 vaccine & recombinant subunit vaccine & $\begin{array}{l}\text { Chongqing Zhifei Biological Products Co. Ltd., } \\
\text { China; Institute of Microbiology, Chinese } \\
\text { Academy of Sciences, China }\end{array}$ \\
\hline 52 & Preclinical & Vaccine & protein-based vaccine & $\begin{array}{l}\text { Coalition for Epidemic Preparedness, Norway; } \\
\text { Dynavax Technologies Corp., USA }\end{array}$ \\
\hline 53 & Preclinical & CDX-005 & $\begin{array}{l}\text { live attenuated virus; codon } \\
\text { deoptimized live attenuated } \\
\text { vaccine }\end{array}$ & $\begin{array}{l}\text { Codagenix Inc., USA; Serum Institute of India } \\
\text { Ltd., India }\end{array}$ \\
\hline 54 & Preclinical & Vaccine & $\begin{array}{l}\text { multitope peptide-based vaccine } \\
\text { (MPV) }\end{array}$ & Covaxx, a unit of United Biomedical Inc., USA \\
\hline 55 & Preclinical & Vaccine & $\begin{array}{l}\text { RNA vaccine; LNP-encapsulated } \\
\text { mRNA }\end{array}$ & Daiichi Sankyo, Japan; University of Tokyo, Japan \\
\hline 56 & Preclinical & Vaccine & $\begin{array}{l}\text { develped on hyper-productive } \\
\text { C1 gene-expression platform }\end{array}$ & $\begin{array}{l}\text { Dyadic International Inc., USA; The Israel Institute } \\
\text { for Biological Research, Israel }\end{array}$ \\
\hline 57 & Preclinical & Vaccine & protein-based vaccine & $\begin{array}{l}\text { Eijkman Institute for Molecular Biology, Indonesia; } \\
\text { PT Bio Farma, Indonesia }\end{array}$ \\
\hline 58 & Preclinical & EXG-5003 & $\begin{array}{l}\text { self-replicating RNA (srRNA) } \\
\text { vaccine }\end{array}$ & Elixirgen Therapeutics Inc., USA \\
\hline 59 & Preclinical & Covigenix & Fusogenix DNA vaccine & Entos Pharmaceuticals, Canada \\
\hline 60 & Preclinical & Vaccine & $\begin{array}{l}\text { vaccine contain virions, viral } \\
\text { proteins at different stages of } \\
\text { viral replication }\end{array}$ & Epitopoietic Research Corp., Belgium \\
\hline 61 & Preclinical & EPV-CoV19 & $\begin{array}{l}\text { protein subunit vaccine; spike } \\
\text { protein }\end{array}$ & Epivax Inc., USA; University of Georgia, USA \\
\hline 62 & Preclinical & mRNA vaccine & $\begin{array}{l}\text { RNA vaccine; mRNA in an } \\
\text { intranasal delivery system }\end{array}$ & Etherna Immunotherapies NV, Belgium \\
\hline 63 & Preclinical & $\begin{array}{l}\text { Vaccine (protein subunit; } \\
\text { virus-like particle) }\end{array}$ & $\begin{array}{l}\text { drosophila S2 insect cell } \\
\text { expression system VLPS }\end{array}$ & $\begin{array}{l}\text { ExpreS2ion Biotechnologies ApS, Denmark; } \\
\text { Adaptvac ApS, Denmark; AGC Biologics, } \\
\text { Denmark; Bavarian Nordic A/S, Denmark }\end{array}$ \\
\hline 64 & Preclinical & Flowvax & protein subunit vaccine; peptide & $\begin{array}{l}\text { Flow Pharma Inc., USA; University of Texas } \\
\text { Medical Branch at Galveston, USA }\end{array}$ \\
\hline 65 & Preclinical & Coroflu & $\begin{array}{l}\text { replicating viral vector; } \mathrm{M} 2- \\
\text { deficient single replication } \\
(\mathrm{M} 2 \mathrm{SR}) \text { influenza vector }\end{array}$ & $\begin{array}{l}\text { Flugen Inc., USA; Bharat Biotech International } \\
\text { Ltd., India; University of Wisconsin-Madison, USA }\end{array}$ \\
\hline 66 & Preclinical & Vaccine & $\begin{array}{l}\text { RNA vaccine; LNP-encapsulated } \\
\text { mRNA cocktail encoding VLP }\end{array}$ & $\begin{array}{l}\text { Fudan University, China; Shanghai Jiao Tong } \\
\text { University, China; RNACure Biopharma, China }\end{array}$ \\
\hline 67 & Preclinical & Li-key peptide vaccine & protein subunit vaccine & $\begin{array}{l}\text { Generex Biotechnology Corp., USA; Biology } \\
\text { Institute of Shandong Academy of Sciences, } \\
\text { China }\end{array}$ \\
\hline 68 & Preclinical & $\begin{array}{l}\text { GV-MVA-VLP vaccine } \\
\text { platform }\end{array}$ & nonreplicating viral vector & $\begin{array}{l}\text { Geovax Labs Inc., USA; Bravovax, China; Sino } \\
\text { Biological Inc., China }\end{array}$ \\
\hline 69 & Preclinical & Vaccine & $\begin{array}{l}\text { nonreplicating viral vector; MVA- } \\
\text { S encoded }\end{array}$ & German Center for Infection Research, Germany \\
\hline 70 & Preclinical & Vaccine & $\begin{array}{l}\text { nonreplicating viral vector; Ad5 S } \\
\text { (GREVAX platform) }\end{array}$ & Greffex Inc., USA \\
\hline 71 & Preclinical & gp-96 vaccine & $\begin{array}{l}\text { protein subunit vaccine; gp-96 } \\
\text { backbone }\end{array}$ & $\begin{array}{l}\text { Heat Biologics Inc., USA; Zolovax Inc., USA; } \\
\text { University of Miami Miller School of Medicine, USA }\end{array}$ \\
\hline 72 & Preclinical & Vaxcelerate vaccine & $\begin{array}{l}\text { based on self-assembling } \\
\text { vaccine (SAV) platform }\end{array}$ & $\begin{array}{l}\text { Hoth Therapeutics Inc., USA; Voltron } \\
\text { Therapeutics Inc., USA }\end{array}$ \\
\hline 73 & Preclinical & COVID-19 vaccine & details not known & Hualan Biological Engineering, China \\
\hline 74 & Preclinical & $|\mathrm{B}| \mathrm{O}-201$ & $\begin{array}{l}\text { protein subunit vaccine; SARS- } \\
\text { CoV-2 spike protein-based }\end{array}$ & Ibio Inc., USA \\
\hline 75 & Preclinical & $\begin{array}{l}\text { SARS-CoV-2 Virus-Like } \\
\text { Particle }\end{array}$ & subunit protein, plant produced & Ibio Inc., USA; Beijing CC-Pharming Ltd., China \\
\hline 76 & Preclinical & $\begin{array}{l}\text { SARS-CoV-2 vaccine } \\
\text { (injectable) }\end{array}$ & $\begin{array}{l}\text { vaccine developed using Sendai } \\
\text { virus vector }\end{array}$ & $\begin{array}{l}\text { ID Pharma Co. Ltd., Japan; Fudan University, } \\
\text { China }\end{array}$ \\
\hline 77 & Preclinical & COVID-19 vaccine & $\begin{array}{l}\text { virus suppressing factor-based } \\
\text { vaccine }\end{array}$ & $\begin{array}{l}\text { Immunemed, South Korea; Seoul National } \\
\text { University Hospital, South Korea }\end{array}$ \\
\hline 78 & Preclinical & Nucleic acid vaccine & $\begin{array}{l}\text { plasmid DNA, needle-free } \\
\text { delivery }\end{array}$ & $\begin{array}{l}\text { Immunomic Therapeutics Inc., USA; Epivax Inc., } \\
\text { USA; Pharmajet Inc., USA }\end{array}$ \\
\hline 79 & Preclinical & Vaccine & $\begin{array}{l}\text { protein subunit vaccine; spike- } \\
\text { based (epitope screening) }\end{array}$ & $\begin{array}{l}\text { Immunoprecise Antibodies Ltd., Canada; EVQLV } \\
\text { Inc., USA; Litevax BV, Netherlands }\end{array}$ \\
\hline
\end{tabular}


TABLE 1 | Continued

\begin{tabular}{|c|c|c|c|c|}
\hline No. & Clinical/preclinical stage & Vaccine name/type & Remark & Organization/Company \\
\hline 80 & Preclinical & Vaccine & $\begin{array}{l}\text { VLP; ADDomer multiepitope } \\
\text { display }\end{array}$ & $\begin{array}{l}\text { Imophoron Ltd., UK; Bristol University's Max } \\
\text { Planck Centre, UK }\end{array}$ \\
\hline 81 & Preclinical & Vaccine & saRNA vaccine & $\begin{array}{l}\text { Imperial College London, UK; Maravai } \\
\text { Lifesciences Inc., USA; Trilink Biotechnologies } \\
\text { Inc., USA }\end{array}$ \\
\hline 82 & Preclinical & Vaccine & $\begin{array}{l}\text { developed based on } \\
\text { recombinant vesicular stomatitis } \\
\text { virus (rVSV) technology }\end{array}$ & International AIDS Vaccine Initiative, USA; Batavia \\
\hline 83 & Preclinical & COVID-19 vaccine & $\begin{array}{l}\text { protein subunit vaccine; outer } \\
\text { membrane vesicle (OMV)-subunit }\end{array}$ & Intravacc, Netherlands; Epivax Inc., USA \\
\hline 84 & Preclinical & Vaccine & DNA vaccine & $\begin{array}{l}\text { Johnson \& Johnson, Belgium; Beth Israel } \\
\text { Deaconess Medical Center, USA }\end{array}$ \\
\hline 85 & Preclinical & Vaccine & $\begin{array}{l}\text { Ad26.COV2-S recombinant } \\
\text { vaccine }\end{array}$ & $\begin{array}{l}\text { Johnson \& Johnson, Belgium; Biomedical } \\
\text { Advanced Research and Development Authority } \\
\text { (BARDA), USA; Emergent Biosolutions Inc., USA; } \\
\text { Catalent Inc., USA }\end{array}$ \\
\hline 86 & Preclinical & Vaccine & polypeptide vaccine & Liaoning Chengda Biotechnology, China \\
\hline 87 & Preclinical & Vaccine & peptide-based vaccine & Ligandal Inc., USA \\
\hline 88 & Preclinical & Vaccine & linear DNA vaccine & Linearx Inc., USA; Takis Biotech, Italy \\
\hline 89 & Preclinical & SARS-CoV-2 vaccine & $\begin{array}{l}\text { protein subunit vaccine; S-2P } \\
\text { protein + CpG } 1018\end{array}$ & $\begin{array}{l}\text { Medigen Biotechnology Corp., Taiwan; National } \\
\text { Institutes of Health, USA }\end{array}$ \\
\hline 90 & Preclinical & MV-014-210 & $\begin{array}{l}\text { live attenuated vaccine (LAV); } \\
\text { spike protein-based }\end{array}$ & Meissa Vaccines Inc., USA \\
\hline 91 & Preclinical & COVID-19 vaccine & $\begin{array}{l}\text { replicating viral vector; replication } \\
\text { competent VSV chimeric virus } \\
\text { technology (VSV } \delta G) \text { delivering } \\
\text { the SARS-CoV-2 Spike (S) } \\
\text { glycoprotein }\end{array}$ & Merck \& Co. Inc., USA; IAVI, USA \\
\hline 92 & Preclinical & COVID-19 vaccine & VLP-based & Metaclipse Therapeutics, USA \\
\hline 93 & Preclinical & Vaccine & $\begin{array}{l}\text { protein subunit vaccine; oral } E \text {. } \\
\text { coli-based protein expression } \\
\text { system of } S \text { and } N \text { proteins }\end{array}$ & MIGAL Galilee Research Institute Ltd., Israel \\
\hline 94 & Preclinical & Vaccine & details not known & Mologic Ltd., UK \\
\hline 95 & Preclinical & COVID-19 & virosome-based vaccine & $\begin{array}{l}\text { Mymetics Corp., Switzerland; Mymetics BV, } \\
\text { Switzerland; Baylor College of Medicine, USA; } \\
\text { Texas Children's Center for Vaccine } \\
\text { Development, USA }\end{array}$ \\
\hline 96 & Preclinical & COVID-19 vaccine & virosome-based vaccine & $\begin{array}{l}\text { Texas Children's Center for Vaccine } \\
\text { Development, USA }\end{array}$ \\
\hline 97 & Preclinical & Vaccine & peptide-based vaccine & Myneo NV, Belgium \\
\hline 98 & Preclinical & Vaccine & $\begin{array}{l}\text { nonreplicating viral vector; [E1-, } \\
\text { E2b-, E3-] hAd5-COVID-19- } \\
\text { spike/nucleocapsid }\end{array}$ & Nantkwest Inc., USA; Immunitybio Inc., USA \\
\hline 99 & Preclinical & COVID-19 vaccine & $\begin{array}{l}\text { based on the rBCG, genetically } \\
\text { engineered to express selected } \\
\text { SARS-CoV-2 proteins }\end{array}$ & $\begin{array}{l}\text { Nascent Biotech Inc., USA; Manhattan } \\
\text { Biosolutions Inc., USA }\end{array}$ \\
\hline 100 & Preclinical & TerraCoV2 & spike protein-based & Noachis Terra Inc., USA \\
\hline 101 & Preclinical & Vaccine & $\begin{array}{l}\text { protein subunit vaccine; synthetic } \\
\text { Long peptide vaccine candidate } \\
\text { for } \mathrm{S} \text { and } \mathrm{M} \text { proteins }\end{array}$ & Oncogen, Malaysia \\
\hline 102 & Preclinical & CORVax12 & $\begin{array}{l}\text { co-administration of TAVO } \\
\text { (plasmid IL-12) with a DNA- } \\
\text { encodable version of the SARS- } \\
\text { CoV-2 spike protein }\end{array}$ & Oncosec Medical Inc., USA \\
\hline 103 & Preclinical & Cell-based vaccine & $\begin{array}{l}\text { irradiated permissive cells } \\
\text { (infected with a high titer virus or } \\
\text { transfected with viral antigens) }\end{array}$ & Orgenesis Inc., USA \\
\hline 104 & Preclinical & Vaccine & peptide-based vaccine & Ose Immunotherapeutics SA, France \\
\hline 105 & Preclinical & VLP vaccine & protein-based vaccine & Osivax, France \\
\hline 106 & Preclinical & COVID-19 vaccine & $\begin{array}{l}\text { whole inactivated virus-based } \\
\text { vaccine }\end{array}$ & Panacea Biotec Ltd., India \\
\hline 107 & Preclinical & Versamune-CoV-2FC & $\begin{array}{l}\text { recombinant fusion S protein- } \\
\text { based }\end{array}$ & PDS Biotechnology Corp., USA \\
\hline
\end{tabular}


TABLE 1 | Continued

\begin{tabular}{|c|c|c|c|c|}
\hline No. & Clinical/preclinical stage & Vaccine name/type & Remark & Organization/Company \\
\hline 108 & Preclinical & $\begin{array}{l}\text { SARS coronavirus } \\
\text { vaccine }\end{array}$ & $\begin{array}{l}\text { receptor-binding domain of the } \\
\text { SARS coronavirus S-protein- } \\
\text { based }\end{array}$ & Phylex Biosciences Inc., USA \\
\hline 109 & Preclinical & Vaccine & NSP10-based vaccine & Predictive Oncology Inc., USA \\
\hline 110 & Preclinical & Vaccine & $\begin{array}{l}\text { adenovirus vectored; spike } \\
\text { protein-based }\end{array}$ & Reithera Srl, Italy \\
\hline 111 & Preclinical & VLP vaccine & protein-based vaccine & Saiba AG, Switzerland \\
\hline 112 & Preclinical & mRNA vaccine & RNA vaccine; LNP-mRNA & Sanofi Pasteur, France; Translate Bio Inc., USA \\
\hline 113 & Preclinical & Vaccine & protein subunit vaccine & $\begin{array}{l}\text { Sanofi Pasteur, France; U.S. Biomedical } \\
\text { Advanced Research and Development Authority, } \\
\text { USA }\end{array}$ \\
\hline 114 & Preclinical & Vaccine & DNA vaccine & Scancell Holdings plc, UK \\
\hline 115 & Preclinical & Vaccine & details not known & SK Bioscience Co. Ltd., South Korea \\
\hline 116 & Preclinical & STI-6991; T-VIVA-19 & $\begin{array}{l}\text { recombinant fusion protein of the } \\
\text { SARS-CoV-2 spike protein S1 } \\
\text { domain and human IgG FC }\end{array}$ & $\begin{array}{l}\text { Sorrento Therapeutics Inc., USA; Smartpharm } \\
\text { Therapeutics Inc., USA }\end{array}$ \\
\hline 117 & Preclinical & OraPro-COVID-19 & $\begin{array}{l}\text { nonreplicating viral vector; oral } \\
\text { Ad5 S }\end{array}$ & Stabilitech Biopharma Ltd., UK \\
\hline 118 & Preclinical & Vivagel (SPL-7013) & astodrimer sodium-based & Starpharma Ltd., Australia \\
\hline 119 & Preclinical & Vaccine & $\begin{array}{l}\text { VSV-receptor binding domain } \\
\text { vaccine }\end{array}$ & $\begin{array}{l}\text { Sumagen, South Korea; International Vaccine } \\
\text { Institute, South Korea }\end{array}$ \\
\hline 120 & Preclinical & VLP vaccine & recombinant protein vaccine & Sysvax Inc., China \\
\hline 121 & Preclinical & COVID-eVax & $\begin{array}{l}\text { DNA-based; encodes a part of } \\
\text { viral spike protein }\end{array}$ & Takis Srl, Italy; Rottapharm Biotech Srl, Italy \\
\hline 122 & Preclinical & Vaccine & bivalent COVID-19 vaccine & Tevogen Bio Inc., USA \\
\hline 123 & Preclinical & mRNA vaccine & RNA vaccine & $\begin{array}{l}\text { Tongji University, China; Stemirna Therapeutics } \\
\text { Co. Ltd., China }\end{array}$ \\
\hline 124 & Preclinical & COVID-19 vaccine & live replicating virus vaccine & $\begin{array}{l}\text { Tonix Pharmaceuticals Holding Corp., USA; } \\
\text { Kansas State University, USA }\end{array}$ \\
\hline 125 & Preclinical & TNX-1800 & $\begin{array}{l}\text { replicating viral vector; horsepox } \\
\text { vector expressing S protein }\end{array}$ & $\begin{array}{l}\text { Tonix Pharmaceuticals Holding Corp., USA; } \\
\text { University of Alberta, USA; Fujifilm Diosynth } \\
\text { Biotechnologies, USA; Southern Research, USA }\end{array}$ \\
\hline 126 & Preclinical & PolyPEPI-SCoV-2 & $\begin{array}{l}\text { consists of } 10 \text { different, 30-amino } \\
\text { acid long synthetic peptides }\end{array}$ & Treos Bio Ltd., UK \\
\hline 127 & Preclinical & Vaccine & details not known & Tulane University, USA \\
\hline 128 & Preclinical & Vaccine & VLP vaccine & Ufovax Inc., USA \\
\hline 129 & Preclinical & Vaccine & $\begin{array}{l}\text { replicating viral vector; influenza } \\
\text { vector expressing RBD }\end{array}$ & University of Hong Kong, Hong Kong \\
\hline 130 & Preclinical & $\begin{array}{l}\text { Measles vector-based } \\
\text { vaccine (PittCoVacc) }\end{array}$ & $\begin{array}{l}\text { replicating viral vector; measles } \\
\text { vector }\end{array}$ & $\begin{array}{l}\text { University of Pittsburgh, USA; Themis Biosciences } \\
\text { Inc., Austria; Coalition for Epidemic Preparedness } \\
\text { Innovations, Norway; Pasteur Institute, France; } \\
\text { Merck \& Co. Inc., USA }\end{array}$ \\
\hline 131 & Preclinical & Protein subunit vaccine & $\begin{array}{l}\text { molecular clamp stabilized spike } \\
\text { protein }\end{array}$ & $\begin{array}{l}\text { University of Queensland, Australia; } \\
\text { Glaxosmithkline plc., UK; Seqirus GmbH, UK; } \\
\text { Dynavax Technologies Corp., USA }\end{array}$ \\
\hline 132 & Preclinical & SARS-CoV-2 vaccine & VLPs peptides/whole virus & University of Sao Paulo, Brazil \\
\hline 133 & Preclinical & Vaccine & $\begin{array}{l}\text { protein subunit vaccine; } \\
\text { adjuvanted microsphere peptide }\end{array}$ & University of Saskatchewan, Canada \\
\hline 134 & Preclinical & Ixiaro & inactivated + CpG 1018 & $\begin{array}{l}\text { Valneva SE, France; Dynavax Technologies Corp., } \\
\text { USA }\end{array}$ \\
\hline 135 & Preclinical & Pepticrad vaccine & $\begin{array}{l}\text { nonreplicating viral vector; } \\
\text { adenovirus-based + HLA- } \\
\text { matched peptides }\end{array}$ & Valo Therapeutics Ltd., Finland \\
\hline 136 & Preclinical & Vaccine & $\begin{array}{l}\text { nanoparticle-based delivery } \\
\text { system }\end{array}$ & $\begin{array}{l}\text { Vault Pharma Inc., USA; University of California, } \\
\text { Los Angeles, USA; Northern Arizona University, } \\
\text { USA }\end{array}$ \\
\hline 137 & Preclinical & COVID-19 oral vaccine & $\begin{array}{l}\text { nonreplicating viral vector; oral } \\
\text { recombinant vaccine for mucosal } \\
\text { and systemic immune responses }\end{array}$ & $\begin{array}{l}\text { Vaxart Inc., USA; Emergent Biosolutions Inc., } \\
\text { USA }\end{array}$ \\
\hline 138 & Preclinical & Peptide vaccine & protein subunit vaccine & Vaxil Bio Ltd., Canada \\
\hline 139 & Preclinical & Vaccine & $\begin{array}{l}\text { enveloped virus-like particle } \\
\text { vaccine }\end{array}$ & $\begin{array}{l}\text { VBI Vaccines Inc., USA; National Research } \\
\text { Council of Canada, Canada }\end{array}$ \\
\hline
\end{tabular}


TABLE 1 | Continued

\begin{tabular}{|c|c|c|c|c|}
\hline No. & Clinical/preclinical stage & Vaccine name/type & Remark & Organization/Company \\
\hline 140 & Preclinical & Vaxipatch vaccine & $\begin{array}{l}\text { dermal patch with a metal } \\
\text { microneedle array for delivery }\end{array}$ & Verndari Inc., USA \\
\hline 141 & Preclinical & Vaccine & spike protein-based & $\begin{array}{l}\text { Vir Biotechnology Inc., USA; Glaxosmithkline plc., } \\
\text { UK }\end{array}$ \\
\hline 142 & Preclinical & Vaccine & spike protein-based & $\begin{array}{l}\text { Viravaxx AG, Austria; Medical University of Vienna, } \\
\text { Austria }\end{array}$ \\
\hline 143 & Preclinical & Vaccine & spike protein-based & $\begin{array}{l}\text { Walter Reed Army Institute of Research, USA; } \\
\text { U.S. Army Medical Research and Development } \\
\text { Command, USA }\end{array}$ \\
\hline 144 & Preclinical & COVID-19 XWG-03 & $\begin{array}{l}\text { protein subunit vaccine; COVID- } \\
19 \text { XWG-03 truncated S (spike) } \\
\text { proteins }\end{array}$ & $\begin{array}{l}\text { Xiamen Innovax Biotech Co. Ltd., China; } \\
\text { Glaxosmithline plc., UK; Xiamen University, China }\end{array}$ \\
\hline 145 & Preclinical & Vaccine & $\begin{array}{l}\text { protein subunit vaccine; } \\
\text { recombinant protein }\end{array}$ & Yisheng Biopharma Co. Ltd., China \\
\hline 146 & Preclinical & ZIP-1642 & mRNA vaccine & $\begin{array}{l}\text { Ziphius Therapeutics NV, Belgium; Ghent } \\
\text { University, Belgium }\end{array}$ \\
\hline
\end{tabular}

For further information visit the following links: https://clinicaltrials.gov \& https://www.bioworld.com/COVID19products\#vac1.

HCoV-229E), DPP4 (dipeptidyl peptidase 4; used by MERS$\mathrm{CoV}$ ), or O-acetylated sialic acid receptor (used by $\mathrm{HCoV}-\mathrm{OC} 43$ and HCoV-HKU1) (Yeager et al., 1992; Krempl et al., 1995; Raj et al., 2013; Huang et al., 2015). It uses the human ACE2 cell receptor to enter the host cell, similar to SARS-CoV and $\mathrm{HCoV}$ NL63 (Hofmann et al., 2005; Ge et al., 2013; Wrapp et al., 2020). So, soluble human ACE2 protein can also be a potential competitor for the ACE2 cell surface receptor, but it can only be achieved when the gene expression of soluble ACE2 is higher than the gene expression of cell surface ACE2 receptor. However, an increase in the concentration of soluble ACE2 in blood found to be associated with chronic cardiac dysfunction (Epelman et al., 2008; Epelman et al., 2009; Ortiz-Pérez et al., 2013). SARS-CoV was found to downregulate ACE2 by binding to it by its spike protein and inflicting severe lung damage (Kuba et al., 2005). Therefore, overexpressed soluble ACE2 may help in neutralizing SARS-CoV-2 by competitively binding to it and free the cellular ACE2 to perform its normal function. A recombinant human ACE2 (APN01) was found to decrease the levels of angiotensin II and plasma IL-6 in different patients diagnosed with ARDS (acute respiratory distress syndrome) may also be utilized for inhibiting SARS-CoV-2 from accessing cellular ACE2 receptor (Zhang et al., 2020a). Soluble human ACE2 protein was shown to bind SARS-CoV with an affinity close to the affinities of monoclonal antibodies and blocks the virus from accessing cellular ACE2 receptor in cell culture (Li et al., 2003; Sui et al., 2004). Interestingly, membrane-anchored metalloproteinase ADAM17 cleaves ACE2 to release the soluble ACE2 domain, which was predicted to have some adverse effects on the heart (Jiang et al., 2014).

Another strategy is to develop anti-ACE2 antibodies that would bind to the human ACE2 protein and block this viral entry, as was shown in SARS-CoV (Li et al., 2003). Unfortunately, there are problems with generating antibodies or protein fragments against the cellular ACE2 as it plays several important roles in controlling cardiovascular diseases including heart attack, diabetes, kidney problems, high blood pressure, etc.
Therefore, inactivating the cellular ACE2 receptor is probably not a viable solution.

Alternatively, an ACE2-Fc fusion protein can also increase the lifespan of the soluble ACE2 protein in circulation and inhibit the virus from accessing the cellular ACE2 receptor. Similarly, in a study, the extracellular ACE2 domain fused to the human IgG1 domain was shown to neutralize the SARS-CoV in vitro ( $\mathrm{Gu}$ et al., 2016), which shows that the use of ACE2-Fc could be a viable solution to block SARS-CoV-2 from infecting human cells. However, this strategy may induce ADE and therefore a thorough investigation is needed to eliminate any adverse effects. The spike protein RBD could also be attached to a human IgG Fc fragment to increase its immunogenicity and stability (Zhang et al., 2009; Li et al., 2011; Du et al., 2013b), as was done in MERS-CoV (Du et al., 2013a). The MERS-CoV spike protein RBD-Fc fusion was found useful in blocking viral cell surface receptor from accessing it by the virus and also stimulated the host immune response against the viral protein domain in mice (Du et al., 2013a). Here one has to consider the mutation of the Fc domain that eliminates its cellular Fc receptor $(\mathrm{Fc} \gamma \mathrm{R})$ binding ability and triggering of cytotoxic effects (Wang et al., 2018; Kang and Jung, 2019). The binding of the Fc region to Fc $\gamma \mathrm{R}$ would activate immune cells to trigger the ADCC pathway and release proinflammatory cytokines, which may lead to cytokine storm (Wang et al., 2018). Therefore, the Fc fusion strategy requires a thorough investigation of toxicity and efficacy, followed by the engineering of the $\mathrm{Fc}$ fragment for immune silencing and increasing effectiveness (Kang and Jung, 2019).

The other alternative strategy would be to generate antibodies or protein-fragments that would bind to the virus itself and protect the cellular ACE2 receptor from binding the virus (Jiang et al., 2020). If a protein or peptide fragment that can mimic the binding domain of ACE2 cell receptor and induce similar changes in conformation, as the receptor likely does, then also it can compete with the ACE2 cell receptor. Recently a 23-mer peptide designed from the ACE2 $\alpha 1$ helix has shown a specific binding affinity toward RBD of S protein from SARS-CoV-2, which shows that the development of a peptide-based 
therapeutics is possible that blocks of this virus interaction with human ACE2 and protecting the cell from virus entry (Zhang G. et al., 2020).

A recent report has shown that murine polyclonal antibodies generated against SARS-CoV spike protein were capable enough to inhibit spike protein-mediated cellular entry of SARS-CoV-2 (Walls et al., 2020). Also, a human monoclonal antibody (47D11), which interacts with a conserved epitope on RBD of spike protein, was found to cross-neutralize with both SARSCoV-2 and SARS-CoV (Wang et al., 2020b). Another antibody having neutralizing property (antibody CR3022) previously isolated from the SARS-CoV infected patient was found to interact with the $\mathrm{S}$ protein $\mathrm{RBD}$ of SARS-CoV-2 at a site different from the ACE2 binding site indicating cross-reactivity of the antibody for having similar structural regions on the spike proteins of both the viruses (Yuan et al., 2020).

SARS-CoV-2 nucleocapsid protein $(\mathrm{N})$ is another vital protein having several critical roles, including viral genome replication, transcription, etc., and therefore is an attractive drug target. Recently a 3D structure (x-ray crystallography) of the aminoterminal RNA-binding domain of this virus $\mathrm{N}$ protein has been elucidated, indicating drug targets (Kang et al., 2020). Broadspectrum antiparasitic drug nitazoxanide has been shown to inhibit the expression of nucleocapsid protein in MERS-CoV and other coronaviruses (Rossignol, 2016). Nitazoxanide also found to suppress proinflammatory cytokines, including IL-6 in mice (Rossignol, 2016). The viral M protein is also highly conserved in evolution among different species (Neuman et al., 2011), and hence, may also be used as a candidate for developing the SARS-CoV-2 therapeutics (Table 2).

Human monoclonal antibody-based drug sarilumab which inhibits IL-6 receptor is now being tested against COVID-19 (Lamb and Deeks, 2018). Monoclonal antibody-based rheumatoid arthritis drug tocilizumab which is also an inhibitor of IL-6 receptor found to be effective in critically ill COVID-19 patients with cytokine storms and elevated IL-6 levels (Venkiteshwaran, 2009; Chakraborty et al., 2020e; Luo et al., 2020; Saha et al., 2020b). Another monoclonal antibody-based drug leronlimab (PRO 140) known to bind to the CCR5 receptor on the $\mathrm{CD}^{+} \mathrm{T}$ lymphocytes is now being tested in COVID-19 clinical trials (Pugach et al., 2008). The proinflammatory chemokine such as $\mathrm{C}$-C motif chemokine ligand 5 (CCL5) also recognized as regulated through activation, normal $\mathrm{T}$ cell expression, and secretion (RANTES), binds to its receptor C-C chemokine receptor type 5 (CCR5) and activates inflammatory responses by directing immune cells to the inflammation site (Vangelista and Vento, 2018). Blocking of CCR5 by leronlimab found to reduce serum IL-6 levels, which is linked with cytokine storm, in critical COVID-19 patients (Patterson et al., 2020). Interleukin-6 (IL-6) plays a vital role in inducing cytokine storm in critical COVID-19 patients and a reduction in IL-6 levels by antiinflammatory drugs is expected to ease CRS and reduce viral loads (Zhang C. et al., 2020).

Anti-inflammatory corticosteroid drug dexamethasone has been suggested recently to treat severe COVID-19 patients with CRS. Dexamethasone reduces the production of cytokines but is also known to inhibit the protective functions of $\mathrm{T}$ cells and $\mathrm{B}$ cells. Therefore, the drug may be used selectively in some severe COVID19 cases, but its general usage in other COVID-19 patients may cause more harm by increasing the viral load in patients due to the inhibition of protective antibody production (Lee et al., 2004; Russell et al., 2020). A recent clinical trial has shown that dexamethasone reduced the death rate among severe COVID-19 patients who needed oxygen support (Table 2). A recent study with severe COVID-19 patients found a direct link between C-reactive protein (CRP) and inflammation where higher CRP levels in the blood show greater inflammation. The study also showed that dexamethasone should only be used in severe COVID-19 patients with CRP levels above $20 \mathrm{mg}$ per deciliter of blood, and the use of dexamethasone should be avoided in COVID-19 patients (under ventilator support) with CRP level below 10 as it may turn out to be fatal (Keller et al., 2020).

Anti-inflammatory rheumatoid arthritis drug baricitinib was found to reduce the levels of cytokines, including IFN- $\gamma$ in severe COVID-19 patients (Huang et al., 2020). High levels of proinflammatory cytokines and chemokines including INF- $\gamma$ in the plasma causes inflammatory cytokine storm that may lead to the occurrence of ARDS in virus-infected patients, therefore use of antiinflammatory drugs in COVID-19 may help in the reduction of severe symptoms (Ye et al., 2020). Another rheumatoid arthritis drug anakinra is known to block the IL-1 receptor and reduce the inflammatory effects of IL-1. Survival rate within patients with hyperinflammatory conditions was found to increase when treated with anakinra (Shakoory et al., 2016).

\section{CONVALESCENT PLASMA}

\section{Therapeutics}

Convalescent plasma (CP) therapy is another procedure now being tested for COVID-19. This therapy is very simple yet effective, where the serum from the COVID-19 recovered persons can treat new patients (Mire et al., 2016). Recovered patients who have suffered from COVID-19 should have an elevated amount of polyclonal antibodies raised by the immune system to prevent new rounds of infection by SARS-CoV-2. Therefore, the plasma harvested from the recovered patients can be transfused to the patients who have contacted the virus (Marano et al., 2016). As the application of convalescent plasma is a well-known procedure and has been utilized before by medical practitioners, it should not be too difficult to apply this procedure to SARS-CoV-2 infected patients. Convalescent plasma has been used previously during the Ebola outbreak in 2014 and was found to be effective in treating Ebola patients (Kraft et al., 2015). A recent report has shown that $\mathrm{CP}$ acquired from recovered patients was effective in treating new COVID-19 infected persons (Duan et al., 2020). One problem using $\mathrm{CP}$ therapy is the significant variability of potency that has been found in the sera of recovered patients in neutralizing the antigen, making it a less viable option in the treatment of patients (Marano et al., 2016). Also, if the number of infected patients is much higher than the recovered patients, it would be tough to get enough CP for transfusion. Although CP therapy is being considered or used for 
TABLE 2 | Ongoing repurposed drug/therapeutic molecule development by different organizations against COVID-19 that are at different phases of clinical trials (updated on July 25, 2020).

\begin{tabular}{|c|c|c|c|c|c|}
\hline No. & Clinical stage & Drug name & Other disease targets & Mode of action & Organization/Company \\
\hline 1 & $\begin{array}{l}\text { Compassionate use } \\
\text { (phase II/III) }\end{array}$ & Ifenprodil (NP-120) & $\begin{array}{l}\text { peripheral circulatory } \\
\text { disorders; idiopathic } \\
\text { pulmonary fibrosis }\end{array}$ & $\begin{array}{l}\text { inhibitor of the } \mathrm{N} \text {-methyl-D-aspartate } \\
\text { receptor }\end{array}$ & $\begin{array}{l}\text { Algernon Pharmaceuticals Inc., Canada; } \\
\text { Nash Pharmaceuticals, Canada }\end{array}$ \\
\hline 2 & $\begin{array}{l}\text { Compassionate use } \\
\text { (phase II/III) }\end{array}$ & DAS-181 & influenza; parainfluenza & $\begin{array}{l}\text { removes sialic acid from the respiratory } \\
\text { cells }\end{array}$ & Ansun Biopharma Inc., USA \\
\hline 3 & $\begin{array}{l}\text { Compassionate use } \\
\text { (phase II) }\end{array}$ & Piclidenoson & rheumatoid arthritis & $\begin{array}{l}\text { antagonism of adenoside } \mathrm{A} 3 \text { receptors; } \\
\text { induce anti-inflammatory effects }\end{array}$ & $\begin{array}{l}\text { Can-Fite Biopharma Ltd., Israel; Lewis } \\
\text { Katz School of Medicine at Temple } \\
\text { University, USA }\end{array}$ \\
\hline 4 & $\begin{array}{l}\text { Compassionate use } \\
\text { (phase III) }\end{array}$ & Siltuximab (Sylvant) & $\begin{array}{l}\text { multicentric Castleman's } \\
\text { disease }\end{array}$ & monoclonal antibody that binds to IL-6 & Eusa Pharma Inc., UK \\
\hline 5 & $\begin{array}{l}\text { Compassionate use } \\
\text { (phase III) }\end{array}$ & $\begin{array}{l}\text { Tocilizumab } \\
\text { (Actemra) }\end{array}$ & $\begin{array}{l}\text { rheumatoid arthritis; } \\
\text { systemic juvenile idiopathic } \\
\text { arthritis }\end{array}$ & $\begin{array}{l}\text { monoclonal antibody against the } \mathrm{IL}-6 \\
\text { receptor }\end{array}$ & Genentech Inc., USA \\
\hline 6 & $\begin{array}{l}\text { Compassionate use } \\
\text { (phase III) }\end{array}$ & Lenzilumab & $\begin{array}{l}\text { chronic myelomonocytic } \\
\text { leukemia; juvenile } \\
\text { myelomonocytic leukemia }\end{array}$ & $\begin{array}{l}\text { humanized monoclonal antibody that } \\
\text { targets CSF2/GM-CSF }\end{array}$ & Humanigen Inc., USA \\
\hline 7 & $\begin{array}{l}\text { Compassionate use } \\
\text { (phase II) }\end{array}$ & IC14 & $\begin{array}{l}\text { acute lung injury; motor } \\
\text { neuron disease }\end{array}$ & $\begin{array}{l}\text { monoclonal antibody; CD14 antigen } \\
\text { inhibitor }\end{array}$ & Implicit Bioscience Ltd., USA \\
\hline 8 & Compassionate use & $\begin{array}{l}\text { Namilumab (IZN- } \\
\text { 101) }\end{array}$ & ankylosing spondylitis & $\begin{array}{l}\text { monoclonal antibody; GM-CSF } \\
\text { antagonist }\end{array}$ & Izana Bioscience Ltd., UK \\
\hline 9 & $\begin{array}{l}\text { Compassionate use } \\
\text { (phase II/III) }\end{array}$ & Mavrilimumab & rheumatoid arthritis & $\begin{array}{l}\text { monoclonal antibody that inhibits } \\
\text { human GM-CSF-receptor }\end{array}$ & Kiniksa Pharmaceuticals Ltd., Bermuda \\
\hline 10 & $\begin{array}{l}\text { Compassionate use } \\
\text { (phase II/III) }\end{array}$ & Giapreza & hypotension & Angiotensin type 1 receptor agonist & La Jolla Pharmaceutical Co., USA \\
\hline 11 & $\begin{array}{l}\text { Compassionate use } \\
\text { (phase I/II) }\end{array}$ & Organicell Flow & regenerative therapy & $\begin{array}{l}\text { acellular product derived from human } \\
\text { amniotic fluid; suppressor of cytokine } \\
\text { activation }\end{array}$ & $\begin{array}{l}\text { Organicell Regenerative Medicine Inc., } \\
\text { USA }\end{array}$ \\
\hline 12 & Compassionate use & $\begin{array}{l}\text { Conestat alfa } \\
\text { (Ruconest) }\end{array}$ & hereditary angioedema & $\begin{array}{l}\text { complement component C1r, C1s } \\
\text { inhibitor }\end{array}$ & Pharming Group, Netherlands \\
\hline 13 & $\begin{array}{l}\text { Compassionate use } \\
\text { (phase II) }\end{array}$ & $\begin{array}{l}\text { PLX cell product } \\
\text { candidates }\end{array}$ & cancer & placenta-based cell therapy & $\begin{array}{l}\text { Pluristem Therapeutics Inc., Israel; } \\
\text { Charite' University of Medicine Berlin, } \\
\text { Germany }\end{array}$ \\
\hline 14 & Compassionate use & Allorx stem cells & anti-aging & $\begin{array}{l}\text { adult mesenchymal stem cell (MSC)- } \\
\text { based therapy }\end{array}$ & $\begin{array}{l}\text { Vitro Diagnostics Inc., USA; Global } \\
\text { Institute of Stem Cell Therapy and } \\
\text { Research Inc. (Giostar), USA }\end{array}$ \\
\hline 15 & $\begin{array}{l}\text { Emergency use } \\
\text { authorization }\end{array}$ & $\begin{array}{l}\text { Bemsivir (generic } \\
\text { remdesivir) }\end{array}$ & ebola & viral RNA polymerase inhibitor & $\begin{array}{l}\text { Beximco Pharmaceuticals Ltd., } \\
\text { Bangladesh; Hetero Labs Ltd., India; } \\
\text { Mylan NV, USA }\end{array}$ \\
\hline 16 & $\begin{array}{l}\text { Emergency use } \\
\text { authorization } \\
\text { (phase III, expanded } \\
\text { access, benefit; } \\
\text { approved in EU) }\end{array}$ & Remdesivir (Veklury) & ebola & viral RNA polymerase inhibitor & $\begin{array}{l}\text { Gilead Sciences Inc., USA; Cipla Ltd., } \\
\text { India; Hetero Labs Ltd., India; Dr. Reddy's } \\
\text { Laboratories Inc., India }\end{array}$ \\
\hline 17 & $\begin{array}{l}\text { Emergency use } \\
\text { authorization } \\
\text { (submitted) }\end{array}$ & MSCs & $\begin{array}{l}\text { regenerative therapy for } \\
\text { various injuries }\end{array}$ & $\begin{array}{l}\text { mesenchymal stromal cell-based } \\
\text { therapy }\end{array}$ & Predictive Biotech, USA \\
\hline 18 & $\begin{array}{l}\text { Emergency use } \\
\text { authorization - } \\
\text { REVOKED (phase III, } \\
\text { no benefit) }\end{array}$ & $\begin{array}{l}\text { Chloroquine/ } \\
\text { hydroxychloroquine } \\
\text { (Plaquenil) }\end{array}$ & malaria & $\begin{array}{l}\text { increases lysosomal pH; membrane } \\
\text { fusion inhibitor }\end{array}$ & $\begin{array}{l}\text { Sanofi SA, France; Amneal } \\
\text { Pharmaceuticals Inc., USA; Rising } \\
\text { Pharma Holdings Inc., USA; University of } \\
\text { Minnesota, USA; Sandoz Inc., Germany; } \\
\text { Bayer AG, Germany; University of } \\
\text { Washington, USA; Patient-Centered } \\
\text { Outcomes Research Institute (PCORI), } \\
\text { USA; Certara Inc., USA; Progenabiome } \\
\text { LLC, USA }\end{array}$ \\
\hline 19 & $\begin{array}{l}\text { Expanded access } \\
\text { (phase II) }\end{array}$ & Eculizumab (Soliris) & $\begin{array}{l}\text { paroxysmal nocturnal } \\
\text { hemoglobinuria; atypical } \\
\text { hemolytic uremic syndrome; } \\
\text { neuromyelitis optica }\end{array}$ & complement C5 inhibitor & Alexion Pharmaceuticals Inc., USA \\
\hline 20 & $\begin{array}{l}\text { Expanded access } \\
\text { (phase III) }\end{array}$ & Inopulse & $\begin{array}{l}\text { pulmonary arterial } \\
\text { hypertension }\end{array}$ & $\begin{array}{l}\text { vasodilator nitric oxide decreases } \\
\text { pressure in the pulmonary arteries; } \\
\text { improves oxygination }\end{array}$ & Bellerophon Therapeutics Inc., USA \\
\hline
\end{tabular}


TABLE 2 | Continued

\begin{tabular}{|c|c|c|c|c|c|}
\hline No. & Clinical stage & Drug name & Other disease targets & Mode of action & Organization/Company \\
\hline 21 & Expanded access & CAP-1002 & $\begin{array}{l}\text { Duchenne muscular } \\
\text { dystrophy; myocardial } \\
\text { infarction }\end{array}$ & $\begin{array}{l}\text { cardiosphere-derived cell replacement } \\
\text { therapy }\end{array}$ & Capricor Therapeutics Inc., USA \\
\hline 22 & $\begin{array}{l}\text { Expanded access } \\
\text { (phase II/III) }\end{array}$ & Ruxolitinib (Jakafi) & myelofibrosis & Janus kinase-1/2 inhibitor & $\begin{array}{l}\text { Incyte Corp., USA; Novartis AG, } \\
\text { Switzerland }\end{array}$ \\
\hline 23 & $\begin{array}{l}\text { Expanded access } \\
\text { (phase II/III) }\end{array}$ & Remestemcel-L & $\begin{array}{l}\text { acute graft versus host } \\
\text { disease (aGVHD) }\end{array}$ & $\begin{array}{l}\text { culture-expanded mesenchymal stem } \\
\text { cell replacement therapy }\end{array}$ & Mesoblast Ltd., Australia \\
\hline 24 & $\begin{array}{l}\text { Expanded access } \\
\text { (phase II/III) }\end{array}$ & Opaganib (Yeliva) & cancer & $\begin{array}{l}\text { inhibitor of the enzyme sphingosine } \\
\text { kinase } 2\end{array}$ & $\begin{array}{l}\text { Redhill Biopharma Ltd., Israel; Apogee } \\
\text { Biotechnology Corp., USA }\end{array}$ \\
\hline 25 & Expanded access & Genosyl DS & $\begin{array}{l}\text { pulmonary arterial } \\
\text { hypertension }\end{array}$ & $\begin{array}{l}\text { nitric oxide delivery system; improves } \\
\text { oxygination }\end{array}$ & Vero Biotech LLC, USA \\
\hline 26 & Phase IV & $\begin{array}{l}\text { Danoprevir (Ganovo) } \\
+ \text { ritonavir }\end{array}$ & hepatitis C; AIDS & viral protease inhibitor & Ascletis Pharma Inc., China \\
\hline 27 & Phase IV & Berberine & $\begin{array}{l}\text { diabetes; hyperlipidemia; } \\
\text { high blood pressure; } \\
\text { gastrointestinal infections }\end{array}$ & $\begin{array}{l}\text { AMP-activated protein kinase (AMPK) } \\
\text { activator; } \alpha \text {-glucosidase inhibitor }\end{array}$ & Chinese Medical Association, China \\
\hline 28 & Phase IV & $\begin{array}{l}\text { Irbesartan (DMX- } \\
\text { 200) }\end{array}$ & hereditary angioedema & $\begin{array}{l}\text { complement component C1r, C1s } \\
\text { inhibitor }\end{array}$ & Dimerix Ltd., Australia \\
\hline 29 & Phase IV & Eritoran & sepsis & $\begin{array}{l}\text { endotoxin inhibitor; lipid A inhibitor; toll- } \\
\text { like receptor } 4 \text { antagonist }\end{array}$ & Eisai Co. Ltd., Japan \\
\hline 30 & Phase IV & $\begin{array}{l}\text { Interferon-beta-1a } \\
\text { (Traumakine) }\end{array}$ & multiple sclerosis & $\begin{array}{l}\text { immunostimulants; interferon beta-1a } \\
\text { replacements }\end{array}$ & Faron Pharmaceuticals, Finland \\
\hline 31 & Phase IV & $\begin{array}{l}\text { Bivalirudin } \\
\text { (Angiomax) }\end{array}$ & $\begin{array}{l}\text { acute coronary syndromes; } \\
\text { hrombosis }\end{array}$ & thrombin inhibitor & Hamad Medical Corp., Qatar \\
\hline 32 & Phase IV & Cyclosporine & $\begin{array}{l}\text { rheumatoid arthritis; } \\
\text { psoriasis; Crohn's disease; } \\
\text { organ rejection }\end{array}$ & $\begin{array}{l}\text { calcineurin inhibitor; } \\
\text { immunosuppressant }\end{array}$ & $\begin{array}{l}\text { Instituto de Investigacion Sanitaria de la } \\
\text { Fundacion Jimenez Diaz, Spain; University } \\
\text { of Pennsylvania, USA }\end{array}$ \\
\hline 33 & Phase IV & $\mathrm{N}$-acetylcysteine & $\begin{array}{l}\text { bronchiectasis; chronic } \\
\text { obstructive pulmonary } \\
\text { disease; cystic fibrosis }\end{array}$ & antioxidant & $\begin{array}{l}\text { Memorial Sloan Kettering Cancer Center, } \\
\text { USA; Cambridge Health Alliance, USA; } \\
\text { Mashhad University of Medical Sciences, } \\
\text { Iran; Shuguang Hospital, China; Hubei } \\
\text { Hospital of } \\
\text { Traditional Chinese Medicine, China; } \\
\text { Jingmen No. } 1 \text { People's Hospital, China; } \\
\text { Tongji Hospital, China }\end{array}$ \\
\hline 34 & Phase IV & $\begin{array}{l}\text { Interferon beta-1a } \\
\text { (Rebif) }\end{array}$ & multiple sclerosis & $\begin{array}{l}\text { immunostimulant; interferon beta-1a } \\
\text { replacement }\end{array}$ & $\begin{array}{l}\text { Merck Group, Germany; French Institut } \\
\text { National de la Sante et de la Recherche } \\
\text { Medicale (INSERM), France }\end{array}$ \\
\hline 35 & Phase IV & Ebastine & $\begin{array}{l}\text { allergic conjunctivitis; } \\
\text { allergic rhinitis; urticaria }\end{array}$ & Histamine $\mathrm{H} 1$ receptor antagonist & $\begin{array}{l}\text { Mianyang Central Hospital, China; Wuhan } \\
\text { Red Cross Hospital, China; West china } \\
\text { Hospital of Sichuan University, China }\end{array}$ \\
\hline 36 & Phase IV & $\begin{array}{l}\text { Sargramostim } \\
\text { (Leukine) }\end{array}$ & $\begin{array}{l}\text { acute radiation syndrome; } \\
\text { bone marrow disorders; } \\
\text { neutropenia }\end{array}$ & $\begin{array}{l}\text { granulocyte stimulant; haematopoiesis } \\
\text { stimulants; neutrophil stimulant }\end{array}$ & Partner Therapeutics Inc., USA \\
\hline 37 & Phase IV & Umifenovir (Arbidol) & influenza & membrane fusion inhibitor & Pharmstandard, Russia \\
\hline 38 & Phase IV & Valsartan & $\begin{array}{l}\text { heart failure; hypertension; } \\
\text { postmyocardial infarction }\end{array}$ & angiotensin type 1 receptor antagonists & Radboud University, Netherlands \\
\hline 39 & Phase IV & $\begin{array}{l}\text { Baloxavir marboxil } \\
\text { (Xofluza) }\end{array}$ & influenza & endonuclease inhibitors & $\begin{array}{l}\text { Roche Holding AG, Switzerland; The First } \\
\text { Affiliated Hospital of Zhejiang University } \\
\text { Medical School, China }\end{array}$ \\
\hline 40 & Phase IV & Carrimycin & cancer & $50 S$ ribosomal subunit inhibitor & Shenyang Tonglian Group Co. Ltd., China \\
\hline 41 & Phase III (no benefit) & $\begin{array}{l}\text { Lopinavir/ritonavir } \\
\text { (Kaletra/Aluvia) }\end{array}$ & AIDS & viral protease inhibitor & Abbvie Inc., USA \\
\hline 42 & Phase III & $\begin{array}{l}\text { Dornase alfa } \\
\text { (Pulmozyme) }\end{array}$ & cystic fibrosis & deoxyribonuclease 1 stimulant & $\begin{array}{l}\text { Acibadem University, Turkey; The } \\
\text { Scientific and Technological Research } \\
\text { Council of Turkey; University College, } \\
\text { London, UK; Feinstein Institute for } \\
\text { Medical Research, USA; Cold Spring } \\
\text { Harbor Laboratory, USA; Northwell } \\
\text { Health, USA; Fondation Ophtalmologique } \\
\text { Adolphe de Rothschild, France; University } \\
\text { Hospital, Strasbourg, France; Hospital } \\
\text { Center Régional Metz-Thionville, France; }\end{array}$ \\
\hline
\end{tabular}

(Continued) 
TABLE 2 | Continued

No. Clinical stage

Drug name

Other disease targets

Mode of action

Organization/Company

University of Missouri-Columbia, USA; Boston Children's Hospital, USA; Brigham and Women's Hospital, USA; University of South Alabama, USA

$\begin{array}{lll}43 & \text { Phase III } & \begin{array}{l}\text { Ravulizumab } \\ \text { (Ultomiris) } \\ \text { Tigerase (dornase } \\ \text { alfa biosimilar) }\end{array} \\ 45 & \text { Phase III } & \begin{array}{l}\text { ASC-09 + ritonavir } \\ \text { (oral tablet) }\end{array} \\ 46 & \text { Phase III } & \text { Almitrine } \\ 47 & \text { Phase III } & \\ 48 & \text { Phase III } & \begin{array}{l}\text { Dapagliflozin } \\ \text { (Farxiga) } \\ \text { Chloroquine }+ \\ \text { interferon beta-1b } \\ \text { Levilimab }\end{array} \\ 50 & \text { Phase III } & \text { NK1 III }+ \text { MSC } \\ 51 & \text { Phase III } & \text { Rivaroxaban }\end{array}$

paroxysmal nocturnal complement C5 inhibitor haemoglobinuria cystic fibrosis

HIV

chronic obstructive pulmonary disease

sodium-glucose transporter 2 inhibitor malaria; multiple sclerosis rheumatoid arthritis myocardial infarction; left ventricular dysfunction deep vein thrombosis; pulmonary embolism

52 Phase III

Methylprednisolone

multiple sclerosis

53 Phase II

54 Phase III

55 Phase III

56 Phase III

57 Phase III

58 Phase III (approved in India)

Ciclesonide

(Alvesco)

Pacritinib

Baricitinib (Olumiant)

Radiation therapy

ENU-200

Favipiravir (Avigan)
Losmapimod

Alteplase (tissue plasminogen activator)

\begin{tabular}{|c|c|}
\hline 61 Phase III & $\begin{array}{l}\text { Emtricitabine/ } \\
\text { tenofovir (Truvada) }\end{array}$ \\
\hline 62 Phase III & Tacrolimus \\
\hline
\end{tabular}

63 Phase III
IMM-101 facioscapulohumeral muscular dystrophy catheter thrombosis; myocardial infarction; pulmonary embolism

AIDS

eczema; psoriasis; allogeneic organ transplant

cancer
DUX4 protein inhibitor; P38 mitogenactivated protein kinase inhibitor fibrinolytic agents; plasminogen activator stimulants

reverse transcriptase inhibitor

bone morphogenetic protein receptor type II modulator; cytokine inhibitor; T cell activation inhibitor dendritic cell stimulant; immunostimulant
Alexion Pharmaceuticals Inc., USA

AO Generium, Russia

Ascletis Pharma Inc., China

Assistance Publique - Hôpitaux de Paris, France; Centre Hospitalier de Chartres,

France

Astrazeneca, UK

Bayer Inc., Germany; Population Health Research Institute, Canada

Biocad, Russia

Biocardia Inc., USA; University of Health Sciences Lahore, Pakistan

Charite University, Germany; Deutsches

Zentrum für Herz-Kreislauf-Forschung,

Germany; Bayer AG, Germany

Chinese research sponsors, China; University of Oxford, UK; University of

Chile, Chile

Covis Pharma, Switzerland

CTI Biopharma Corp., USA

Eli Lilly and Co., USA; Incyte Corp., USA

Emory University, USA; others

Ennaid Therapeutics LLC, USA

Fujifilm Holdings Corp., Japan; Fujifilm Toyama Chemical Co. Ltd., Japan; Medivector Inc., USA; Zhejiang Hisun Pharmaceutical Co. Ltd., China; Sihuan Pharmaceutical Holdings Group Ltd., China; Genentech Inc., USA; Appili Therapeutics Inc., Canada; Glenmark Pharmaceuticals Ltd., India; Dr. Reddy's Laboratories, India

Fulcrum Therapeutics Inc., USA

Genentech Inc., USA; University of Colorado Denver, USA; Negovsky Reanimatology Research Institute, Russia; Sklifosovsky Institute of Emergency Care, Russia

Gilead Sciences Inc., USA

Hospital Universitari de Bellvitge, Spain; Institut d'Investigació Biomèdica de Bellvitge, Spain Immodulon Therapeutics Ltd., UK; Biocan Rx, Canada; Canadian Cancer Trials Group; Canadian Cancer Society Research Institute; Atgen Canada Inc.; Canadian Centre for Applied Research in 
TABLE 2 | Continued

\begin{tabular}{|c|c|c|c|c|c|}
\hline No. & Clinical stage & Drug name & Other disease targets & Mode of action & Organization/Company \\
\hline & & & & & $\begin{array}{l}\text { Cancer Control; Ontario Institute for } \\
\text { Cancer Research, Canada }\end{array}$ \\
\hline 64 & Phase III & Bacmune (MV-130) & respiratory tract infections & immunostimulant & $\begin{array}{l}\text { Immunotek, USA; Bioclever } 2005 \text { SL, } \\
\text { Spain }\end{array}$ \\
\hline 65 & Phase III & $\begin{array}{l}\text { Darunavir/cobicistat } \\
\text { (Prezcobix) }\end{array}$ & AIDS & $\begin{array}{l}\text { cytochrome P } 450 \text { enzyme system } \\
\text { inhibitor; HIV protease inhibitor }\end{array}$ & Johnson \& Johnson, USA \\
\hline 66 & Phase III & $\begin{array}{l}\text { Hydroxychloroquine } \\
\text { and other lupus } \\
\text { therapies }\end{array}$ & malaria; lupus & $\begin{array}{l}\text { increases lysosomal pH; membrane } \\
\text { fusion inhibitor; immunosuppressant }\end{array}$ & Lupus Therapeutics, USA \\
\hline 67 & Phase III & Colchicine & $\begin{array}{l}\text { familial mediterranean fever; } \\
\text { gout }\end{array}$ & tubulin polymerisation inhibitor & Montreal Heart Institute, Canada \\
\hline 68 & Phase III & Doxycycline & exanthema; acne & $30 S$ ribosomal subunit inhibitor & Nantes University Hospital, France \\
\hline 69 & Phase III & Famotidine & gastritis; peptic ulcer & histamine $\mathrm{H} 2$ receptor antagonist & $\begin{array}{l}\text { Northwell Health, USA; Cold Spring } \\
\text { Harbor Laboratory, USA }\end{array}$ \\
\hline 70 & Phase III & Hydroxychloroquine & malaria & $\begin{array}{l}\text { autophagy inhibitor; phospholipase A2 } \\
\text { inhibitor }\end{array}$ & Novartis, Switzerland \\
\hline 71 & Phase III & Canakinumab (llaris) & $\begin{array}{l}\text { systemic juvenile idiopathic } \\
\text { arthritis; active Still's } \\
\text { disease }\end{array}$ & Interleukin 1 beta inhibitor & Novartis, Switzerland \\
\hline 72 & Phase III & Octagam 10\% & $\begin{array}{l}\text { idiopathic } \\
\text { thrombocytopenic purpura; } \\
\text { Immunodeficiency disorder }\end{array}$ & immunostimulant & Octapharma USA Inc., USA \\
\hline 73 & Phase III & CD24Fc & $\begin{array}{l}\text { graft-versus host disease } \\
\text { (GVHD) }\end{array}$ & $\begin{array}{l}\text { interleukin } 1 \text { beta inhibitor; interleukin } 6 \\
\text { inhibitor; tumour necrosis factor alpha } \\
\text { inhibitor }\end{array}$ & Oncoimmune Inc., USA \\
\hline 74 & Phase III & $\begin{array}{l}\text { Azithromycin } \\
\text { (Zithromax) }\end{array}$ & $\begin{array}{l}\text { bacterial infections; acute } \\
\text { sinusitis }\end{array}$ & $50 S$ ribosomal subunit inhibitor & Pfizer Inc., USA \\
\hline 75 & Phase III & $\begin{array}{l}\text { REGN-COV2 } \\
(\text { REGN-10933 + } \\
\text { REGN-10987) }\end{array}$ & viral infection & antibody; virus internalisation inhibitor & Regeneron Pharmaceuticals Inc., USA \\
\hline 76 & Phase III & Dactolisib (RTB-101) & cancer & $\begin{array}{l}\text { phosphatidylinositol } 3 \text { kinase (PI3K) } \\
\text { inhibitor; mammalian target of } \\
\text { rapamycin (mTOR) inhibitor }\end{array}$ & Restorbio Inc., USA; Adicet Bio Inc., USA \\
\hline 77 & Phase III & Bucillamine & gout; rheumatoid arthritis & $\begin{array}{l}\text { immunomodulator; xanthine oxidase } \\
\text { inhibitor }\end{array}$ & $\begin{array}{l}\text { Revive Therapeutics Ltd., Canada; } \\
\text { Novotech Pty Ltd., Australia }\end{array}$ \\
\hline 78 & Phase III & Oseltamivir (Tamiflu) & influenza & $\begin{array}{l}\text { neuraminidase inhibitor; exocytosis } \\
\text { inhibitor }\end{array}$ & Roche Holding AG, Switzerland \\
\hline 79 & Phase III & $\begin{array}{l}\text { Tocilizumab } \\
\text { (Actemra) }\end{array}$ & rheumatoid arthritis & IL-6 receptor inhibitor & Roche Holding AG, Switzerland \\
\hline 80 & Phase III & $\begin{array}{l}\text { Nitazoxanide (NT- } \\
\text { 300) }\end{array}$ & antiparasitic & $\begin{array}{l}\text { nucleocapsid protein inhibitor; suppress } \\
\text { IL-6 production }\end{array}$ & Romark Laboratories LC, USA \\
\hline 81 & Phase III & $\begin{array}{l}\text { Enoxaparin } \\
\text { (Lovenox) }\end{array}$ & $\begin{array}{l}\text { deep vein thrombosis; } \\
\text { embolism; myocardial } \\
\text { infarction }\end{array}$ & factor Xa inhibitor; thrombin inhibitor & Sanofi, France \\
\hline 82 & Phase III & Dipyridamole & $\begin{array}{l}\text { stroke; transient ischaemic } \\
\text { attack }\end{array}$ & platelet aggregation inhibitor & $\begin{array}{l}\text { UConn Health, USA; University of } \\
\text { Michigan, USA; Rutgers University, USA; } \\
\text { Boehringer Ingelheim GmbH, Germany }\end{array}$ \\
\hline 83 & Phase III & Tradipitant & atopic dermatitis & $\begin{array}{l}\text { neurokinin-1 receptor (NK-1R) } \\
\text { antagonist }\end{array}$ & $\begin{array}{l}\text { Vanda Pharmaceuticals Inc., USA; } \\
\text { University of Illinois at Chicago, USA }\end{array}$ \\
\hline 84 & Phase $\|/ I\|$ & ABX-464 & $\begin{array}{l}\text { AIDS; rheumatoid arthritis; } \\
\text { ulcerative colitis }\end{array}$ & $\begin{array}{l}\text { immunostimulant; rev gene product } \\
\text { inhibitor; RNA cap-binding protein } \\
\text { modulator }\end{array}$ & Abivax, France \\
\hline 85 & Phase II/III & Multistem & $\begin{array}{l}\text { neurological, inflammatory, } \\
\text { cardiovascular diseases }\end{array}$ & multipotent adult progenitor cell therapy & Athersys Inc., USA \\
\hline 86 & Phase II/III & BDB-001 & tumor & $\begin{array}{l}\text { immunomodulator; toll-like receptor } 7 \\
\text { agonist; toll-like receptor } 8 \text { agonist }\end{array}$ & $\begin{array}{l}\text { Beijing Defengrei Biotechnology Co., } \\
\text { China }\end{array}$ \\
\hline 87 & Phase II/III & BC-007 & $\begin{array}{l}\text { dilated cardiomyopathy; } \\
\text { chronic fatigue syndrome }\end{array}$ & $\begin{array}{l}\text { immunomodulators; virus replication } \\
\text { inhibitor }\end{array}$ & Berlin Cures Holding AG, Germany \\
\hline 88 & Phase $\|/ I\|$ & Vazegepant & migraine & $\begin{array}{l}\text { calcitonin gene-related peptide receptor } \\
\text { antagonist }\end{array}$ & $\begin{array}{l}\text { Biohaven Pharmaceutical Holding Co. } \\
\text { Ltd., USA }\end{array}$ \\
\hline 89 & Phase $\|/ I\|$ & $\begin{array}{l}\text { Sarconeos (BIO- } \\
101)\end{array}$ & $\begin{array}{l}\text { duchenne muscular } \\
\text { dystrophy }\end{array}$ & $\begin{array}{l}\text { proto-oncogene protein c-mas-1 } \\
\text { agonist }\end{array}$ & Biophytis SA, France \\
\hline
\end{tabular}


TABLE 2 | Continued

\begin{tabular}{|c|c|c|c|c|c|}
\hline No. & Clinical stage & Drug name & Other disease targets & Mode of action & Organization/Company \\
\hline 90 & Phase II/III & Lactoferrin & Crohn's disease & chelating agent; immunomodulator & $\begin{array}{l}\text { Cairo University, Egypt; National Research } \\
\text { Center, Egypt; Egyptian Military Medical } \\
\text { Services }\end{array}$ \\
\hline 91 & Phase $\|/ I\|$ & $\begin{array}{l}\text { Sofosbuvir, } \\
\text { daclatasvir, } \\
\text { hydroxychloroquine; } \\
\text { sofosbuvir, ribavirin }\end{array}$ & hepatitis C; malaria & $\begin{array}{l}\text { virus replication inhibitor; membrane } \\
\text { fusion inhibitor }\end{array}$ & $\begin{array}{l}\text { Cairo University, Egypt; Tanta University, } \\
\text { Egypt }\end{array}$ \\
\hline 92 & Phase II/III & Ambrisentan & $\begin{array}{l}\text { pulmonary arterial } \\
\text { hypertension }\end{array}$ & endothelin A receptor antagonist & $\begin{array}{l}\text { Cambridge University Hospitals, UK; NHS } \\
\text { Foundation Trust, UK }\end{array}$ \\
\hline 93 & Phase II/III & Dociparstat sodium & $\begin{array}{l}\text { acute myeloid leukaemia; } \\
\text { pancreatic cancer }\end{array}$ & $\begin{array}{l}\text { cathepsin G inhibitor; chemokine } \\
\text { CXCL12 inhibitor }\end{array}$ & Chimerix Inc., USA \\
\hline 94 & Phase II/III & $\begin{array}{l}\text { PRO-140 } \\
\text { (leronlimab) }\end{array}$ & AIDS & $\begin{array}{l}\text { binds to CCR5 receptor to block HIV; } \\
\text { membrane fusion inhibitor }\end{array}$ & Cytodyn Inc., USA \\
\hline 95 & Phase II/III & EB-05 & rheumatoid arthritis & toll-like receptor 4 antagonist & $\begin{array}{l}\text { Edesa Biotech Inc., Canada; Novimmune } \\
\text { SA, Switzerland }\end{array}$ \\
\hline 96 & Phase II/III & $\begin{array}{l}\text { Nafamostat } \\
\text { mesylate }\end{array}$ & pancreatitis & $\begin{array}{l}\text { serine protease TMPRSS-2 inhibitor; } \\
\text { membrane fusion inhibitor }\end{array}$ & Ensysce Biosciences Inc., USA \\
\hline 97 & Phase $\|/ I\|$ & EDP-1815 & atopic dermatitis; psoriasis & Immunomodulator & $\begin{array}{l}\text { Evelo Biosciences Inc., USA; Cambridge } \\
\text { University Hospitals NHS Foundation } \\
\text { Trust, UK }\end{array}$ \\
\hline 98 & Phase II/III & Levamisole & parasitic worm infections & Immunomodulator & $\begin{array}{l}\text { Fasa University of Medical Sciences, Iran; } \\
\text { Ain Shams University, Egypt; Cairo } \\
\text { University, Egypt }\end{array}$ \\
\hline 99 & Phase II/III & Pamrevlumab & $\begin{array}{l}\text { idiopathic pulmonary } \\
\text { fibrosis; pancreatic cancer }\end{array}$ & connective tissue growth factor inhibitor & Fibrogen Inc., USA \\
\hline 100 & Phase II/III & Bevacizumab & cancer & $\begin{array}{l}\text { Angiogenesis inhibitors; vascular } \\
\text { endothelial growth factor A inhibitor }\end{array}$ & Genentech Inc., USA \\
\hline 101 & Phase II/III & $\begin{array}{l}\text { Atazanavir; } \\
\text { daclatasvir; } \\
\text { sofosbuvir; favipiravir }\end{array}$ & hepatitis C, AIDS, ebola & viral protein/protease/replicase inhibitor & Hospital do Coracao, Brazil \\
\hline 102 & Phase II/III & $\mathrm{IFX}-1$ & $\begin{array}{l}\text { sepsis; systemic } \\
\text { inflammatory response } \\
\text { syndrome }\end{array}$ & $\begin{array}{l}\text { complement C5a inhibitor; inflammation } \\
\text { mediator modulator }\end{array}$ & Inflarx, Germany \\
\hline 103 & Phase II/III & Cannabidiol & $\begin{array}{l}\text { fragile X syndrome; } \\
\text { epilepsy; pain; insomnia; } \\
\text { anxiety }\end{array}$ & $\begin{array}{l}\text { antioxidant; cannabinoid receptor CB1/ } \\
\text { CB2 inverse agonists; serotonin } 1 \\
\text { receptor modulator }\end{array}$ & $\begin{array}{l}\text { Innocan Pharma Corp., Israel; Ramot at } \\
\text { Tel Aviv University, Israel; University } \\
\text { of Sao Paulo, Brazil }\end{array}$ \\
\hline 104 & Phase II/III & Candesartan & hypertension & angiotensin receptor blocker & Medical University of Vienna, Austria \\
\hline 105 & Phase I/III & Ivermectin & parasitic infections & viral protein maturation inhibitor & Medincell SA, France; Merck, USA \\
\hline 106 & Phase $\| / I I I$ & Previfenon & heart and brain disease & reduce inflammation & $\begin{array}{l}\text { Melisa Institute Genomics \& Proteomics } \\
\text { Research, Chile; Universidad Australia }\end{array}$ \\
\hline 107 & Phase $\|/ I\|$ & $\begin{array}{l}\mathrm{NA}-831 \text { + atazanavir } \\
\text { + dexamethasone }\end{array}$ & $\begin{array}{l}\text { alzheimer's disease; AIDS; } \\
\text { rheumatoid arthritis }\end{array}$ & $\begin{array}{l}\text { HIV protease inhibitor; } \\
\text { immunosuppressant }\end{array}$ & Neuroactiva Inc., USA \\
\hline 108 & Phase $\|/ I\|$ & Aviptadil (RLF-100) & pulmonary sarcoidosis & $\begin{array}{l}\text { vasoactive intestinal peptide receptor } \\
\text { agonist }\end{array}$ & $\begin{array}{l}\text { Neurorx Inc., USA; Relief Therapeutics } \\
\text { Holding SA, Switzerland }\end{array}$ \\
\hline 109 & Phase II/III (benefit) & Dexamethasone & $\begin{array}{l}\text { skin diseases; asthma; } \\
\text { cancer; rheumatoid arthritis }\end{array}$ & $\begin{array}{l}\text { glucocorticoid receptor agonist; } \\
\text { immunosuppressant }\end{array}$ & Oxford University, UK \\
\hline 110 & Phase II/III & PTC-299 & acute myeloid leukaemia & dihydroorotate dehydrogenase inhibitor & PTC Therapeutics Inc., USA \\
\hline 111 & $\begin{array}{l}\text { Phase II/III (no benefit, } \\
\text { halted) }\end{array}$ & Sarilumab (Kevzara) & rheumatoid arthritis & IL-6 receptor inhibitor & $\begin{array}{l}\text { Regeneron Pharmaceuticals Inc., USA; } \\
\text { Sanofi SA, France }\end{array}$ \\
\hline 112 & Phase $\|/\| \|$ & $\begin{array}{l}\text { Olokizumab + RPH- } \\
104\end{array}$ & rheumatoid arthritis; pain & IL-6 inhibitor; interleukin 1 beta inhibitor & $\begin{array}{l}\text { R-Pharm JSC, Russia; Cromos Pharma } \\
\text { LLC }\end{array}$ \\
\hline 113 & Phase $\|/ I\|$ & $\begin{array}{l}\text { Emapalumab } \\
\text { (Gamifant) }\end{array}$ & $\begin{array}{l}\text { haemophagocytic } \\
\text { lymphohistiocytosis }\end{array}$ & interferon gamma inhibitor & Swedish Orphan Biovitrum, Sweden \\
\hline 114 & Phase II/III & Anakinra (Kineret) & rheumatoid arthritis & IL-1 receptor inhibitor & Swedish Orphan Biovitrum, Sweden \\
\hline 115 & Phase II/III & RESP-301 & influenza & $\begin{array}{l}\text { antiviral; prevent membrane fusion; } \\
\text { virus replication inhibitor }\end{array}$ & Thirty Respiratory Ltd., UK \\
\hline 116 & Phase II/III & Losartan & $\begin{array}{l}\text { diabetic nephropathies; } \\
\text { heart failure; hypertension }\end{array}$ & angiotensin type 1 receptor antagonist & University of Minnesota, USA \\
\hline 117 & Phase II/III & $\begin{array}{l}\text { Generic } \\
\text { hydroxychloroquine }\end{array}$ & malaria & $\begin{array}{l}\text { autophagy inhibitor; phospholipase A2 } \\
\text { inhibitor }\end{array}$ & $\begin{array}{l}\text { Walter and Eliza Hall Institute of Medical } \\
\text { Research, Australia; Iqvia Inc., USA }\end{array}$ \\
\hline 118 & Phase II & MRx-4DP0004 & asthma & immunomodulator & 4D Pharma plc, UK \\
\hline 119 & Phase II & Masitinib & mastocytosis; cancer & tyrosine kinase inhibitor & AB Science, France \\
\hline
\end{tabular}


TABLE 2 | Continued

\begin{tabular}{|c|c|c|c|c|c|}
\hline No. & Clinical stage & Drug name & Other disease targets & Mode of action & Organization/Company \\
\hline 120 & Phase ॥ & Ibrutinib & $\begin{array}{l}\text { chronic lymphocytic } \\
\text { leukaemia; graft-versus- } \\
\text { host disease }\end{array}$ & tyrosine kinase inhibitor & $\begin{array}{l}\text { Abbvie Inc., USA; Janssen Research \& } \\
\text { Development LLC, USA }\end{array}$ \\
\hline 121 & Phase II & $\begin{array}{l}\text { LY-3819253 (LY- } \\
\text { CoV555) }\end{array}$ & viral infection & human antibody inhibitor of cell entry & $\begin{array}{l}\text { Abcellera Biologics Inc., Canada; Eli Lilly } \\
\text { and Co., USA }\end{array}$ \\
\hline 122 & Phase ॥ & ATI-450 & rheumatoid arthritis & MAP-kinase-activated kinase 2 inhibitor & $\begin{array}{l}\text { Aclaris Therapeutics Inc., USA; University } \\
\text { of Kansas Medical Center, USA }\end{array}$ \\
\hline 123 & Phase II & $\begin{array}{l}\text { Epoprostenol } \\
\text { (Ventoprost) }\end{array}$ & pulmonary hypertension & $\begin{array}{l}\text { epoprostenol receptor agonist; platelet } \\
\text { aggregation inhibitor }\end{array}$ & $\begin{array}{l}\text { Aerogen Pharma Ltd., Ireland; Ohio State } \\
\text { University, USA }\end{array}$ \\
\hline 124 & Phase II & Razuprotafib & $\begin{array}{l}\text { diabetic macular oedema; } \\
\text { diabetic retinopathy; ocular } \\
\text { hypertension }\end{array}$ & $\begin{array}{l}\text { angiopoietin modulator; receptor-like } \\
\text { protein tyrosine phosphatase inhibitor; } \\
\text { TIE-2 receptor agonist }\end{array}$ & $\begin{array}{l}\text { Aerpio Pharmaceuticals Inc., USA; } \\
\text { Quantum Leap Healthcare Collaborative, } \\
\text { USA }\end{array}$ \\
\hline 125 & Phase II & $\begin{array}{l}\text { Apilimod (LAM- } \\
\text { O02A) }\end{array}$ & non-Hodgkin's lymphoma & phosphatidylinositol 3 kinase inhibitor & $\begin{array}{l}\text { Al Therapeutics Inc., USA; Yale University, } \\
\text { USA; Quantitative Biosciences Institute at } \\
\text { UC San Francisco, USA }\end{array}$ \\
\hline 126 & Phase II & Vadadustat & anaemia & $\begin{array}{l}\text { hypoxia-inducible factor-proline } \\
\text { dioxygenase inhibitor }\end{array}$ & Akebia Therapeutics Inc., USA \\
\hline 127 & Phase ॥ & $\begin{array}{l}\text { Rapamycin } \\
\text { (Sirolimus) }\end{array}$ & $\begin{array}{l}\text { coronary artery restenosis; } \\
\text { lymphangioleiomyomatosis; } \\
\text { renal transplant rejection; } \\
\text { fibroma }\end{array}$ & $\begin{array}{l}\text { immunosuppressant; methylmalonyl } \\
\text { CoA mutase stimulant; MTOR protein } \\
\text { inhibitor; T Iymphocyte inhibitor }\end{array}$ & $\begin{array}{l}\text { Alexandria University, Egypt; University of } \\
\text { Texas at San Antonio }\end{array}$ \\
\hline 128 & Phase ॥ & ANG-3777 & $\begin{array}{l}\text { acute kidney injury; } \\
\text { pneumonia; renal failure }\end{array}$ & hepatocyte growth factor stimulant & Angion Biomedica Corp., USA \\
\hline 129 & Phase ॥ & APN-01 & $\begin{array}{l}\text { cancer; diabetic } \\
\text { nephropathies; heart failure; } \\
\text { hypertension }\end{array}$ & $\begin{array}{l}\text { ACE stimulant; virus internalisation } \\
\text { inhibitor }\end{array}$ & Apeiron Biologics, Austria \\
\hline 130 & Phase II & AT-001 & rheumatoid arthritis & immunomodulator & Applied Therapeutics Inc., USA \\
\hline 131 & Phase ॥ & Cilastatin (MetaBlok) & $\begin{array}{l}\text { cancer; sepsis; acute } \\
\text { kidney injury }\end{array}$ & dipeptidase inhibitor & Arch Biopartners Inc., Canada \\
\hline 132 & Phase ॥ & Ramelteon & insomnia & melatonin MT1/MT2 receptor agonist & $\begin{array}{l}\text { Associacao Fundo de Incentivo a } \\
\text { Pesquisa, Brazil }\end{array}$ \\
\hline 133 & Phase ॥ & $\begin{array}{l}\text { Acalabrutinib } \\
\text { (Calquence) }\end{array}$ & $\begin{array}{l}\text { chronic lymphocytic } \\
\text { leukaemia }\end{array}$ & tyrosine kinase inhibitor & Astrazeneca, UK \\
\hline 134 & Phase II & MEDI-3506 & $\begin{array}{l}\text { atopic dermatitis; diabetic } \\
\text { nephropathies }\end{array}$ & IL-33 inhibitor & Astrazeneca, UK \\
\hline 135 & Phase II & AT-527 & hepatitis C & hepatitis C virus NS 5 protein inhibitor & Atea Pharmaceuticals Inc., USA \\
\hline 136 & Phase II & ATYR-1923 & pulmonary sarcoidosis & neuropilin-2 modulator & Atyr Pharma Inc., USA \\
\hline 137 & Phase II & Co-trimoxazole & bacterial infection & $\begin{array}{l}\text { tetrahydrofolate dehydrogenase } \\
\text { inhibitor }\end{array}$ & $\begin{array}{l}\text { Bangabandhu Sheikh Mujib Medical } \\
\text { University, Bangladesh; Anwar Khan } \\
\text { Modern Medical College and Hospital, } \\
\text { Bangladesh; Mugda Medical College and } \\
\text { Hospital, Bangladesh }\end{array}$ \\
\hline 138 & Phase II & Ribavirin (Virazole) & hepatitis $\mathrm{C}$ & nucleic acid inhibitor & Bausch Health Cos. Inc., Canada \\
\hline 139 & Phase II & Bemcentinib & cancer & Axl receptor tyrosine kinase inhibitor & Bergenbio, Norway \\
\hline 140 & Phase ॥ & Gelsolin (rhu-pGSN) & $\begin{array}{l}\text { bronchitis; cystic fibrosis; } \\
\text { systemic inflammatory } \\
\text { response syndrome }\end{array}$ & protein replacement & Bioaegis Therapeutics Inc., USA \\
\hline 141 & Phase ॥ & $\mathrm{BIO}-11006$ & cancer & $\begin{array}{l}\text { myristoylated alanine rich } \mathrm{C} \text { kinase } \\
\text { substrate inhibitor }\end{array}$ & Biomarck Pharmaceuticals Ltd., USA \\
\hline 142 & Phase ॥ & BLD-2660 & fibrosis & $\begin{array}{l}\text { calpain inhibitor; virus replication } \\
\text { inhibitor }\end{array}$ & $\begin{array}{l}\text { Blade Therapeutics Inc., USA; Clinipace } \\
\text { Worldwide, USA }\end{array}$ \\
\hline 143 & Phase ॥ & Abatacept & $\begin{array}{l}\text { juvenile rheumatoid arthritis; } \\
\text { psoriatic arthritis; } \\
\text { rheumatoid arthritis }\end{array}$ & T cell activation inhibitor & Bristol Myers Squibb Co., USA \\
\hline 144 & Phase II & Ozanimod & multiple sclerosis & $\begin{array}{l}\text { sphingosine } 1 \text { phosphate receptor } \\
\text { modulator }\end{array}$ & $\begin{array}{l}\text { Bristol Myers Squibb Co., USA; Celgene } \\
\text { Corp., USA; Laval University, Canada }\end{array}$ \\
\hline 145 & Phase ॥ & Clevudine & hepatitis B & DNA-directed DNA polymerase inhibitor & $\begin{array}{l}\text { Bukwang Pharmaceutical Co. Ltd., South } \\
\text { Korea }\end{array}$ \\
\hline 146 & Phase II & Desidustat & anaemia & $\begin{array}{l}\text { hypoxia-inducible factor-proline } \\
\text { dioxygenase inhibitor }\end{array}$ & Cadila Healthcare Ltd., India \\
\hline 147 & Phase ॥ & $\begin{array}{l}\text { Pegylated Interferon } \\
-\alpha 2 b\end{array}$ & $\begin{array}{l}\text { hepatitis B; hepatitis C; } \\
\text { malignant melanoma }\end{array}$ & interferon alpha stimulant & Cadila Healthcare Ltd., India \\
\hline
\end{tabular}


TABLE 2 | Continued

\begin{tabular}{|c|c|c|c|c|c|}
\hline No. & Clinical stage & Drug name & Other disease targets & Mode of action & Organization/Company \\
\hline 148 & Phase II & $\begin{array}{l}\text { Auxora (CM-4620- } \\
\text { IE) }\end{array}$ & pancreatitis & $\begin{array}{l}\text { immunosuppressant; ORAI1 protein } \\
\text { inhibitor; STIM1 protein inhibitor }\end{array}$ & Calcimedica Inc., USA \\
\hline 149 & Phase ॥ & Thalidomide & leprosy; multiple myeloma & $\begin{array}{l}\text { angiogenesis inhibitor; } \\
\text { immunosuppressant; tumour necrosis } \\
\text { factor inhibitor }\end{array}$ & Celgene Corp., USA \\
\hline 150 & Phase ॥ & $\begin{array}{l}\text { Mesenchymal stem } \\
\text { cells (MSCs) }\end{array}$ & $\begin{array}{l}\text { regenerative therapy for } \\
\text { various injuries }\end{array}$ & allogeneic cell-based therapy & Celltex Therapeutics Corp., USA \\
\hline 151 & Phase II & CERC-002 & Crohn's disease & $\begin{array}{l}\text { tumour necrosis factor ligand } \\
\text { superfamily member } 14 \text { inhibitor }\end{array}$ & Cerecor Inc., USA \\
\hline 152 & Phase ॥ & Clazakizumab & $\begin{array}{l}\text { psoriatic arthritis; } \\
\text { rheumatoid arthritis; renal } \\
\text { transplant rejection }\end{array}$ & IL-6 inhibitor & $\begin{array}{l}\text { Columbia University, USA; NYU Langone } \\
\text { Health, USA; Vitaeris INC, Canada; } \\
\text { Cedars-Sinai Medical Center, USA; Johns } \\
\text { Hopkins University, USA; Medical } \\
\text { University of Vienna, Austria }\end{array}$ \\
\hline 153 & Phase II & TXA-127 & $\begin{array}{l}\text { duchenne muscular } \\
\text { dystrophy; epidermolysis } \\
\text { bullosa; limb girdle } \\
\text { muscular dystrophies; } \\
\text { marfan syndrome; muscular } \\
\text { dystrophies; stroke }\end{array}$ & $\begin{array}{l}\text { proto-oncogene protein c-mas-1 } \\
\text { agonist }\end{array}$ & Constant Therapeutics Inc., USA \\
\hline 154 & Phase ॥ & $\begin{array}{l}\text { Garadacimab (CSL- } \\
\text { 312) }\end{array}$ & hereditary angioedema & factor Xlla inhibitor & CSL Behring, USA \\
\hline 155 & Phase ॥ & DUR-928 & $\begin{array}{l}\text { acute kidney injury; } \\
\text { alcoholic hepatitis; liver } \\
\text { disorders }\end{array}$ & $\begin{array}{l}\text { inflammation mediator modulator; lipid } \\
\text { modulator }\end{array}$ & Durect Corp., USA \\
\hline 156 & Phase II (IND filed) & $\begin{array}{l}\text { Dantrolene } \\
\text { (Ryanodex) }\end{array}$ & $\begin{array}{l}\text { spinal cord injury; stroke; } \\
\text { cerebral palsy; multiple } \\
\text { sclerosis }\end{array}$ & $\begin{array}{l}\text { ryanodine receptor calcium release } \\
\text { channel modulator }\end{array}$ & Eagle Pharmaceuticals Inc., USA \\
\hline 157 & Phase ॥ & $\begin{array}{l}\text { Peginterferon } \\
\text { lambda }\end{array}$ & hepatitis D & interleukin 29 receptor agonist & $\begin{array}{l}\text { Eiger Biopharmaceuticals Inc., USA; } \\
\text { Stanford University School of Medicine, } \\
\text { USA }\end{array}$ \\
\hline 158 & Phase II & LY-3127804 & tumor & angiopoietin-2 inhibitor & Eli Lilly and Co., USA \\
\hline 159 & Phase ॥ & $M-5049$ & immunological disorders & $\begin{array}{l}\text { toll-like receptor } 7 \text { antagonist; toll-like } \\
\text { receptor } 8 \text { antagonist }\end{array}$ & EMD Serono Inc., USA \\
\hline 160 & Phase II & $\begin{array}{l}\text { Leukocyte cell } \\
\text { therapy (Allocetra) }\end{array}$ & $\begin{array}{l}\text { graft-versus-host disease; } \\
\text { inflammation }\end{array}$ & cell replacement; immunomodulator & $\begin{array}{l}\text { Enlivex Therapeutics Ltd., Israel; Israel } \\
\text { Innovation Authority }\end{array}$ \\
\hline 161 & Phase II & Itolizumab & plaque psoriasis & CD6 antigen inhibitor & Equillium Inc., USA; Biocon Ltd., India \\
\hline 162 & Phase ॥ & Tecarfarin & $\begin{array}{l}\text { thromboembolism; } \\
\text { thrombosis }\end{array}$ & vitamin $\mathrm{K}$ epoxidase inhibitor & Espero Biopharma Inc., USA \\
\hline 163 & Phase II & $\begin{array}{l}\text { Niclosamide (FW- } \\
\text { 1022) }\end{array}$ & viral infection & $\begin{array}{l}\text { angiotensin type } 2 \text { receptor modulator; } \\
\text { virus replication inhibitor }\end{array}$ & Firstwave Bio Inc., USA \\
\hline 164 & Phase II & Quinine (GLS-1200) & sinusitis & G protein-coupled receptor agonist & Geneone Life Science Inc., South Korea \\
\hline 165 & Phase II & Otilimab & rheumatoid arthritis & $\begin{array}{l}\text { granulocyte macrophage colony } \\
\text { stimulating factor antagonist }\end{array}$ & Glaxosmithkline, UK \\
\hline 166 & Phase ॥ & $\begin{array}{l}\text { Antroquinonol } \\
\text { (Hocena) }\end{array}$ & $\begin{array}{l}\text { atopic dermatitis; cancer; } \\
\text { hepatitis B; hyperlipidaemia }\end{array}$ & $\begin{array}{l}\text { epidermal growth factor receptor } \\
\text { modulator }\end{array}$ & Golden Biotechnology Corp., Taiwan \\
\hline 167 & Phase ॥ & $\begin{array}{l}\text { GAMUNEX-C } \\
\text { (intravenous immune } \\
\text { globulin) }\end{array}$ & $\begin{array}{l}\text { chronic inflammatory } \\
\text { demyelinating } \\
\text { polyradiculoneuropathy; } \\
\text { idiopathic } \\
\text { thrombocytopenic purpura; } \\
\text { immunodeficiency disorders }\end{array}$ & $\begin{array}{l}\text { amyloid beta-protein inhibitors; } \\
\text { immunostimulants }\end{array}$ & $\begin{array}{l}\text { Grifols, Spain; U.S. Biomedical Advanced } \\
\text { Research and Development } \\
\text { Authority, USA; FDA }\end{array}$ \\
\hline 168 & Phase ॥ & $\begin{array}{l}\text { Allogeneic stem cell } \\
\text { therapy (HLCM-051) }\end{array}$ & graft-versus-host disease & cell replacements & Healios K.K., Japan \\
\hline 169 & Phase ॥ & Aprepitant (Cinvanti) & $\begin{array}{l}\text { chemotherapy-induced } \\
\text { nausea and vomiting }\end{array}$ & $\begin{array}{l}\text { neurokinin } 1 \text { receptor antagonists; Virus } \\
\text { replication inhibitor }\end{array}$ & Heron Therapeutics Inc., USA \\
\hline 170 & Phase II & HB-adMSCs & $\begin{array}{l}\text { Alzheimer's disease; } \\
\text { rheumatoid arthritis; } \\
\text { traumatic brain injuries }\end{array}$ & cell replacements & Hope Biosciences LLC, USA \\
\hline 171 & Phase ॥ & Genistein & acute radiation syndrome & $\begin{array}{l}\text { antioxidant; apoptosis inhibitor; } \\
\text { haematopoietic cell growth factor } \\
\text { stimulant; protein tyrosine kinase } \\
\text { inhibitor }\end{array}$ & Humanetics Corp., USA \\
\hline
\end{tabular}


TABLE 2 | Continued

\begin{tabular}{|c|c|c|c|c|c|}
\hline No. & Clinical stage & Drug name & Other disease targets & Mode of action & Organization/Company \\
\hline 172 & Phase ॥ & Interleukin-2 & rheumatoid arthritis; lupus & regulatory T-lymphocyte stimulant & $\begin{array}{l}\text { Iltoo Pharma, France; Assistance Publique } \\
\text { - Hopitaux de Paris, France }\end{array}$ \\
\hline 173 & Phase ॥ & CYTO-201 & $\begin{array}{l}\text { immunomodulator; opioid } \\
\text { receptor antagonist }\end{array}$ & autoimmune disorders; cancer & $\begin{array}{l}\text { Immune Therapeutics Inc., USA; Cytocom } \\
\text { Inc., USA }\end{array}$ \\
\hline 174 & Phase ॥ & $\begin{array}{l}\text { Vidofludimus (IMU- } \\
\text { 838) }\end{array}$ & $\begin{array}{l}\text { Crohn's disease; multiple } \\
\text { sclerosis }\end{array}$ & $\begin{array}{l}\text { dihydroorotate dehydrogenase inhibitor; } \\
\text { virus replication inhibitor }\end{array}$ & Immunic Inc., USA \\
\hline 175 & Phase ॥ & Xpro-1595 & $\begin{array}{l}\text { Alzheimer's disease; } \\
\text { nonalcoholic } \\
\text { steatohepatitis; solid } \\
\text { tumours }\end{array}$ & $\begin{array}{l}\text { immunostimulant; tumour necrosis } \\
\text { factor alpha inhibitor }\end{array}$ & Inmune Bio Inc., USA \\
\hline 176 & Phase II & Avdoralimab & $\begin{array}{l}\text { liver cancer; nonsmall cell } \\
\text { lung cancer; solid tumours }\end{array}$ & complement C5a receptor antagonist & $\begin{array}{l}\text { Innate Pharma, France; Marseille } \\
\text { Immunopole, France }\end{array}$ \\
\hline 177 & Phase II & Nangibotide & $\begin{array}{l}\text { myocardial infarction; septic } \\
\text { shock }\end{array}$ & TREML1 protein inhibitor & Inotrem, France \\
\hline 178 & Phase II & $\begin{array}{l}\text { Hydroxychloroquine } \\
+ \text { azithromycin }\end{array}$ & $\begin{array}{l}\text { malaria; acute sinusitis; } \\
\text { bacterial infections }\end{array}$ & $\begin{array}{l}\text { autophagy inhibitor; phospholipase A2 } \\
\text { inhibitor; } 50 \text { S ribosomal subunit inhibitor }\end{array}$ & $\begin{array}{l}\text { Intermountain Healthcare, USA; The } \\
\text { Lundquist Institute, USA }\end{array}$ \\
\hline 179 & Phase II & $\begin{array}{l}\text { Tocilizumab } \\
\text { biosimilar }\end{array}$ & rheumatoid arthritis & IL-6 receptor antagonist & Jinyu Biotechnology Co. Ltd., China \\
\hline 180 & Phase ॥ & Decitabine & $\begin{array}{l}\text { acute myeloid leukaemia; } \\
\text { chronic myeloid leukaemia; } \\
\text { myelodysplastic syndromes }\end{array}$ & DNA methylation inhibitor & Johns Hopkins University, USA \\
\hline 181 & Phase ॥ & Crizanlizumab & vaso-occlusive crisis & P selectin inhibitor & $\begin{array}{l}\text { Johns Hopkins University, USA; Novartis } \\
\text { AG, Switzerland; Socar Research SA, } \\
\text { Switzerland; Brigham and Women's } \\
\text { Hospital, USA }\end{array}$ \\
\hline 182 & Phase II & $\begin{array}{l}\text { Alvelestat (MPH- } \\
966)\end{array}$ & $\begin{array}{l}\text { alpha } 1 \text {-antitrypsin } \\
\text { deficiency; type } 2 \text { diabetes } \\
\text { mellitus }\end{array}$ & leucocyte elastase inhibitor & Kafrelsheikh University, Egypt \\
\hline 183 & Phase II & KB-109 & bacterial infections & microbiome modulator & Kaleido Biosciences Inc., USA \\
\hline 184 & Phase II & $\begin{array}{l}\text { Selinexor (KPT-330, } \\
\text { Xpovio) }\end{array}$ & $\begin{array}{l}\text { diffuse large B cell } \\
\text { lymphoma; multiple } \\
\text { myeloma }\end{array}$ & exportin-1 protein inhibitor & Karyopharm Therapeutics Inc., USA \\
\hline 185 & Phase II & Telmisartan & $\begin{array}{l}\text { cardiovascular disorders; } \\
\text { hypertension }\end{array}$ & $\begin{array}{l}\text { ACE inhibitors; angiotensin type } 2 \\
\text { receptor antagonist }\end{array}$ & $\begin{array}{l}\text { Laboratorio Elea Phoenix, Argentina; } \\
\text { University of Hawaii, Honolulu }\end{array}$ \\
\hline 186 & Phase II & Fenretinide (LAU-7b) & cystic fibrosis & retinoic acid receptor agonist & Laurent Pharmaceuticals Inc., Canada \\
\hline 187 & Phase II & $\begin{array}{l}\text { Tranexamic acid } \\
\text { (LB-1148) }\end{array}$ & $\begin{array}{l}\text { cardiogenic shock; post- } \\
\text { surgical adhesions; } \\
\text { postoperative ileus; septic } \\
\text { shock }\end{array}$ & $\begin{array}{l}\text { antifibrinolytic agent; serine protease } \\
\text { inhibitor }\end{array}$ & Leading Biosciences Inc., USA \\
\hline 188 & Phase II & Secukinumab & $\begin{array}{l}\text { ankylosing spondylitis; } \\
\text { plaque psoriasis; psoriatic } \\
\text { arthritis }\end{array}$ & IL17A protein inhibitor & $\begin{array}{l}\text { Lomonosov Moscow State University, } \\
\text { Russia }\end{array}$ \\
\hline 189 & Phase II & Thiolanox & $\begin{array}{l}\text { cystic fibrosis; } \\
\text { mycobacterial infections }\end{array}$ & guanylate cyclase stimulant & Mallinckrodt plc, UK; Novoteris LLC, USA \\
\hline 190 & Phase ॥ & $\begin{array}{l}\text { OT-101+ } \\
\text { artemisinin }\end{array}$ & cancer; malaria & $\begin{array}{l}\text { transforming growth factor beta2 } \\
\text { inhibitor; virus replication inhibitor; free } \\
\text { radical-mediated damage }\end{array}$ & Mateon Therapeutics Inc., USA \\
\hline 191 & Phase II & Fisetin & aging; cancer & $\begin{array}{l}\text { antioxidant; PI3K/AKT/mTOR pathway } \\
\text { inhibitor; anti-proliferative agent; } \\
\text { topoisomerase inhibitor; inhibitor of pro- } \\
\text { inflammatory cytokines }\end{array}$ & Mayo Clinic, USA \\
\hline 192 & Phase II & Ibudilast (MN-166) & $\begin{array}{l}\text { asthma; stroke; multiple } \\
\text { sclerosis }\end{array}$ & phosphodiesterase inhibitor & Medicinova Inc., USA \\
\hline 193 & Phase ॥ & Fingolimod (Gilenya) & multiple sclerosis & $\begin{array}{l}\text { apoptosis stimulant; } \\
\text { immunosuppressant; sphingosine } 1 \\
\text { phosphate receptor modulator }\end{array}$ & Novartis, Switzerland \\
\hline 194 & Phase II & $\mathrm{NanO} 2$ & acute ischemic stroke & $\begin{array}{l}\text { diagnostic imaging enhancer; oxygen } \\
\text { carrier }\end{array}$ & Nuvox Pharma LLC, USA \\
\hline 195 & Phase ॥ & Camostat mesylate & pancreatitis & $\begin{array}{l}\text { serine protease TMPRSS-2 inhibitor; } \\
\text { membrane fusion inhibitor }\end{array}$ & Ono Pharmaceuticals Inc., Japan \\
\hline 196 & Phase II & $\begin{array}{l}\text { Calcifediol } \\
\text { (Rayaldee) }\end{array}$ & $\begin{array}{l}\text { secondary } \\
\text { hyperparathyroidism }\end{array}$ & calcitriol receptor agonist & Opko Health Inc., USA \\
\hline
\end{tabular}


TABLE 2 | Continued

\begin{tabular}{|c|c|c|c|c|c|}
\hline No. & Clinical stage & Drug name & Other disease targets & Mode of action & Organization/Company \\
\hline 197 & Phase ॥ & OP-101 & adrenoleucodystrophy & $\begin{array}{l}\text { I-kappa B kinase inhibitor; NF kappa B } \\
\text { kinase inhibitor; nuclear importation } \\
\text { inhibitor }\end{array}$ & Orpheris Inc., USA \\
\hline 198 & Phase ॥ & Vafidemstat & $\begin{array}{l}\text { autistic disorder; } \\
\text { schizophrenia; Alzheimer's } \\
\text { disease; multiple sclerosis }\end{array}$ & $\begin{array}{l}\text { lysine specific demethylase } 1 \text { inhibitor; } \\
\text { monoamine oxidase B inhibitor }\end{array}$ & Oryzon Genomics, Spain \\
\hline 199 & Phase ॥ & lloprost & $\begin{array}{l}\text { arterial occlusive disorders; } \\
\text { pulmonary arterial } \\
\text { hypertension }\end{array}$ & epoprostenol agonist & Rigshospitalet, Denmark \\
\hline 200 & Phase ॥ & Tofacitinib & $\begin{array}{l}\text { psoriatic arthritis; } \\
\text { rheumatoid arthritis; } \\
\text { ulcerative colitis }\end{array}$ & $\begin{array}{l}\text { immunosuppressant; janus kinase } \\
\text { inhibitor }\end{array}$ & $\begin{array}{l}\text { Pfizer Inc., USA; Yale University, USA; } \\
\text { Universita Politecnica delle Marche, Italy }\end{array}$ \\
\hline 201 & Phase II & Plitidepsin (Aplidin) & multiple myeloma & $\begin{array}{l}\text { apoptosis stimulant; cell cycle inhibitor; } \\
\text { protein synthesis inhibitor }\end{array}$ & Pharmamar SA, Spain \\
\hline 202 & Phase II & PB-1046 & $\begin{array}{l}\text { cardiomyopathies; } \\
\text { pulmonary arterial } \\
\text { hypertension }\end{array}$ & $\begin{array}{l}\text { vasoactive intestinal peptide type } \| \\
\text { receptor agonist }\end{array}$ & Phasebio Pharmaceuticals Inc., USA \\
\hline 203 & Phase ॥ & PUL-042 & $\begin{array}{l}\text { chronic obstructive } \\
\text { pulmonary disease; } \\
\text { haematological } \\
\text { malignancies }\end{array}$ & $\begin{array}{l}\text { immunostimulant; toll-like receptor } \\
\text { agonist }\end{array}$ & Pulmotect Inc., USA \\
\hline 204 & Phase ॥ & AMY-101 & $\begin{array}{l}\text { gingivitis; periodontitis; } \\
\text { paroxysmal nocturnal } \\
\text { haemoglobinuria }\end{array}$ & complement C3 inhibitor & $\begin{array}{l}\text { Amyndas Pharmaceuticals Inc., USA; } \\
\text { Quartesian LLC, USA }\end{array}$ \\
\hline 205 & Phase ॥ & RBT-9 & kidney diseases & organ protective activity & $\begin{array}{l}\text { Renibus Therapeutics Inc., USA; Cascade } \\
\text { Chemistry Inc., USA }\end{array}$ \\
\hline 206 & Phase ॥ & $\begin{array}{l}\text { Interleukin-7 (CYT- } \\
\text { 107) }\end{array}$ & cancer, AIDS, sepsis & IL-7 receptor agonist & $\begin{array}{l}\text { Revimmune, USA; University Hospital, } \\
\text { Limoges, France; Amarex Clinical } \\
\text { Research, USA; Memorial Sloan Kettering } \\
\text { Cancer Center, USA; Washington } \\
\text { University School of Medicine, USA }\end{array}$ \\
\hline 207 & Phase ॥ & EIDD-2801 & $\begin{array}{l}\text { chikungunya, ebola, } \\
\text { influenza }\end{array}$ & virus replication inhibitor & $\begin{array}{l}\text { Ridgeback Biotherapeutics LP, USA; } \\
\text { Emory University, USA; Merck \& Co. Inc., } \\
\text { USA }\end{array}$ \\
\hline 208 & Phase II & Gimsilumab & ankylosing spondylitis & $\begin{array}{l}\text { granulocyte macrophage colony } \\
\text { stimulating factor antagonist }\end{array}$ & $\begin{array}{l}\text { Roivant Sciences Ltd., Switzerland; } \\
\text { Altasciences Co. Inc. }\end{array}$ \\
\hline 209 & Phase II & $\begin{array}{l}\text { STI-5656 (abivertinib } \\
\text { maleate) }\end{array}$ & cancer & $\begin{array}{l}\text { epidermal growth factor receptor } \\
\text { antagonist }\end{array}$ & Sorrento Therapeutics Inc., USA \\
\hline 210 & Phase II & Estradiol patch & menopausal syndrome & estrogen receptor agonist & Stony Brook University Hospital, USA \\
\hline 211 & Phase II & $\begin{array}{l}\text { Interferon-beta-1a } \\
\text { (SNG-001) }\end{array}$ & $\begin{array}{l}\text { chronic obstructive } \\
\text { pulmonary disease; } \\
\text { influenza }\end{array}$ & $\begin{array}{l}\text { immunostimulant; interferon beta } \\
\text { stimulant }\end{array}$ & Synairgen plc, UK \\
\hline 212 & Phase II & Axatilimab & $\begin{array}{l}\text { chronic graft versus host } \\
\text { disease }\end{array}$ & $\begin{array}{l}\text { antibody inhibitor of colony stimulating } \\
\text { factor } 1 \text { receptor }\end{array}$ & Syndax Pharmaceuticals, USA \\
\hline 213 & Phase ॥ & $\begin{array}{l}\text { Interferon beta- } 1 b+ \\
\text { clofazimine }\end{array}$ & $\begin{array}{l}\text { multiple sclerosis; leprosy; } \\
\text { tuberculosis }\end{array}$ & $\begin{array}{l}\text { immunomodulator; interferon beta } \\
\text { stimulant; adenosine triphosphatase } \\
\text { inhibitor; P-glycoprotein inhibitor; } \\
\text { phospholipase A2 inhibitor }\end{array}$ & The University of Hong Kong, Hong Kong \\
\hline 214 & Phase II & Anti-PD-1 antibody & Alzheimer's disease; cancer & amyloid beta-protein inhibitor & $\begin{array}{l}\text { The University of Hong Kong, Hong Kong; } \\
\text { Queen Mary Hospital, Hong Kong; } \\
\text { Southeast University, China }\end{array}$ \\
\hline 215 & Phase ॥ & Infliximab & $\begin{array}{l}\text { Crohn's disease; ulcerative } \\
\text { colitis; rheumatoid arthritis; } \\
\text { ankylosing spondylitis; } \\
\text { psoriasis; psoriatic arthritis }\end{array}$ & tumour necrosis factor alpha inhibitor & $\begin{array}{l}\text { Tufts Medical Center, USA; National } \\
\text { Institutes of Health, USA }\end{array}$ \\
\hline 216 & Phase ॥ & Zilucoplan & $\begin{array}{l}\text { paroxysmal nocturnal } \\
\text { haemoglobinuria; } \\
\text { myasthenia gravis }\end{array}$ & complement C5 inhibitor & $\begin{array}{l}\text { Ghent University Hospital, Belgium; UCB } \\
\text { Pharma, Belgium }\end{array}$ \\
\hline 217 & Phase II & Tranexamic acid & $\begin{array}{l}\text { cardiogenic shock; post- } \\
\text { surgical adhesions; } \\
\text { postoperative ileus; septic } \\
\text { shock }\end{array}$ & $\begin{array}{l}\text { antifibrinolytic agent; serine protease } \\
\text { inhibitor }\end{array}$ & $\begin{array}{l}\text { University of Alabama at Birmingham, } \\
\text { USA; Leading Biosciences Inc., USA; } \\
\text { Duke University, USA; The Emmes Co. } \\
\text { LLC, USA; Eunice Kennedy Shriver }\end{array}$ \\
\hline
\end{tabular}


TABLE 2 | Continued

\begin{tabular}{|c|c|c|c|c|c|}
\hline No. & Clinical stage & Drug name & Other disease targets & Mode of action & Organization/Company \\
\hline & & & & & $\begin{array}{l}\text { National Institute of Child Health and } \\
\text { Human Development, USA }\end{array}$ \\
\hline 218 & Phase ॥ & $\mathrm{C} 21$ & $\begin{array}{l}\text { idiopathic pulmonary } \\
\text { fibrosis }\end{array}$ & angiotensin type 2 receptor agonist & $\begin{array}{l}\text { Vicore Pharma, Sweden; Orphan Reach, } \\
\text { UK }\end{array}$ \\
\hline 219 & Phase II & Maraviroc & AIDS & $\begin{array}{l}\text { CCR5 receptor antagonist; virus } \\
\text { internalisation inhibitor }\end{array}$ & $\begin{array}{l}\text { Viiv Healthcare, USA; Hospital Clinic de } \\
\text { Barcelona, Spain; Hospital Universitario } \\
\text { Infanta Leonor, Spain; Rhode Island } \\
\text { Hospital, USA }\end{array}$ \\
\hline 220 & Phase II & $\begin{array}{l}\text { Merimepodib } \\
\text { (Vicromax) }\end{array}$ & hepatitis C; psoriasis & $\begin{array}{l}\text { immunosuppressant; inosine } \\
\text { monophosphate dehydrogenase } \\
\text { inhibitor }\end{array}$ & Viralclear Pharmaceuticals Inc., USA \\
\hline 221 & Phase II & Elpida (Elsulfavirine) & AIDS & $\begin{array}{l}\text { nonnucleoside reverse transcriptase } \\
\text { inhibitor }\end{array}$ & Viriom Inc., USA \\
\hline 222 & Phase II & $\mathrm{PH}-94 \mathrm{~B}$ & social phobia & chemoreceptor cell modulator & Vistagen Therapeutics Inc., USA \\
\hline 223 & Phase II & Fluvoxamine & $\begin{array}{l}\text { obsessive-compulsive } \\
\text { disorders; social phobia }\end{array}$ & serotonin uptake inhibitor & Washington University, USA \\
\hline 224 & Phase II & XAV-19 & viral infection & $\begin{array}{l}\text { coronavirus spike glycoprotein } \\
\text { modulator }\end{array}$ & $\begin{array}{l}\text { Xenothera SAS, France; LFB SA, France; } \\
\text { Nantes University Hospital, France; } \\
\text { BPIfrance }\end{array}$ \\
\hline 225 & Phase I/II & T-COVID & viral infection & immunomodulator & Altimmune Inc., USA \\
\hline 226 & Phase $1 / 11$ & CYNK-001 & $\begin{array}{l}\text { multiple myeloma; acute } \\
\text { myeloid leukaemia; } \\
\text { glioblastoma }\end{array}$ & $\begin{array}{l}\text { antibody-dependent cell cytotoxicity; } \\
\text { natural killer cell replacement }\end{array}$ & $\begin{array}{l}\text { Celularity Inc., USA; Sorrento } \\
\text { Therapeutics Inc., USA; United } \\
\text { Therapeutics Corp., USA }\end{array}$ \\
\hline 227 & Phase I/II & CAStem & acute lung injury & cell replacements & Chinese Academy of Sciences, China \\
\hline 228 & Phase $1 / 11$ & $\begin{array}{l}\text { NKG2D-ACE2 CAR- } \\
\text { NK cells }\end{array}$ & pneumonia & immunomodulator & $\begin{array}{l}\text { Chongqing Public Health Medical Center, } \\
\text { China; Chongqing Sidemu Biotechnology } \\
\text { Technology Co. Ltd., China }\end{array}$ \\
\hline 229 & Phase l/II & Brequinar & acute myeloid leukaemia & $\begin{array}{l}\text { dihydroorotate dehydrogenase inhibitor; } \\
\text { immunosuppressant }\end{array}$ & Clear Creek Bio Inc., USA \\
\hline 230 & Phase $1 / / 1$ & Meplazumab & malaria; viral infection & metalloprotease inhibitor & $\begin{array}{l}\text { Jiangsu Pacific Meinuoke } \\
\text { Biopharmaceutical Co., China; Fourth } \\
\text { Military Medical University, China }\end{array}$ \\
\hline 231 & Phase I/II & Lanadelumab & hereditary angioedema & plasma kallikrein inhibitors & $\begin{array}{l}\text { Radboud University, Netherlands; Takeda, } \\
\text { Japan }\end{array}$ \\
\hline 232 & Phase I/II & $\begin{array}{l}\text { RAPA-501-ALLO } \\
\text { off-the-shelf cells }\end{array}$ & $\begin{array}{l}\text { amyotrophic lateral } \\
\text { sclerosis }\end{array}$ & autologous $T$ cell immunotherapy & $\begin{array}{l}\text { Rapa Therapeutics LLC, USA; } \\
\text { Hackensack Meridian Health, USA }\end{array}$ \\
\hline 233 & Phase $1 / \|$ & Pentoxifylline & peripheral artery disease & phosphodiesterase inhibitor & Sadat City University, Egypt \\
\hline 234 & Phase $1 / I \mid$ & SBI-101 & acute kidney injury & $\begin{array}{l}\text { immunosuppressant; stem cell } \\
\text { modulator }\end{array}$ & Sentien Biotechnologies Inc., USA \\
\hline 235 & Phase I/II & Ulinastatin & $\begin{array}{l}\text { pancreatitis; vascular } \\
\text { disorders }\end{array}$ & $\begin{array}{l}\text { serine protease inhibitor; trypsin } \\
\text { inhibitor }\end{array}$ & Stanford University, USA \\
\hline 236 & Phase I/II & Tramadol & pain & $\begin{array}{l}\text { opioid mu receptor agonist; serotonin } \\
\text { uptake inhibitor }\end{array}$ & Tanta University, Egypt \\
\hline 237 & Phase $\mid / / I$ & TL-895 & viral infection & tyrosine kinase inhibitor & Telios Pharma Inc., USA \\
\hline 238 & Phase I & Agent-797 & cancer; viral infection & $\begin{array}{l}\text { immunologic cytotoxicity; natural killer } \\
\text { cell replacement }\end{array}$ & Agenus Inc., USA \\
\hline 239 & Phase I & Ampion & osteoarthritis; eye disorders & $\begin{array}{l}\text { cytokine inhibitor; inflammation mediator } \\
\text { inhibitor; IL-6 inhibitor }\end{array}$ & Ampio Pharmaceuticals Inc., USA \\
\hline 240 & Phase I & APL-9 & $\begin{array}{l}\text { paroxysmal nocturnal } \\
\text { haemoglobinuria }\end{array}$ & complement C3 inhibitor & Apellis Pharmaceuticals Inc., USA \\
\hline 241 & Phase I & Solnatide & $\begin{array}{l}\text { acute lung injury, pulmonary } \\
\text { oedema }\end{array}$ & sodium channel agonist & $\begin{array}{l}\text { Apeptico Forschung und Entwicklung } \\
\text { GmbH, Austria }\end{array}$ \\
\hline 242 & Phase I & $\mathrm{T}-89$ & chronic stable angina & $\begin{array}{l}\text { improve blood circulation; boost energy } \\
\text { metabolism; reduce blood thickness }\end{array}$ & $\begin{array}{l}\text { Arbor Pharmaceuticals Inc., USA; Tasly } \\
\text { Pharmaceutical Group Co. Ltd., China }\end{array}$ \\
\hline 243 & Phase I & BX-U001 & $\begin{array}{l}\text { inflammatory bowel } \\
\text { diseases; rheumatoid } \\
\text { arthritis }\end{array}$ & cell replacement & Baylx Inc., USA \\
\hline 244 & Phase I & Galidesivir & $\begin{array}{l}\text { zika; ebola; marburg; yellow } \\
\text { fever }\end{array}$ & RNA replicase inhibitor & Biocryst Pharmaceuticals Inc., USA \\
\hline 245 & Phase I & BAT-2020 & viral infection & unknown & Bio-Thera Solutions, China \\
\hline 246 & Phase I & BRII-198 & viral infection & human monoclonal antibody treatment & $\begin{array}{l}\text { Brii Biosciences, China; Columbia } \\
\text { University, USA; Tsinghua University, } \\
\text { China; }\end{array}$ \\
\hline
\end{tabular}


TABLE 2 | Continued

\begin{tabular}{|c|c|c|c|c|c|}
\hline No. & Clinical stage & Drug name & Other disease targets & Mode of action & Organization/Company \\
\hline & & & & & $\begin{array}{l}\text { 3rd People's Hospital of Shenzhen, } \\
\text { China; TSB Therapeutics (Beijing) Co. } \\
\text { Ltd., China }\end{array}$ \\
\hline 247 & Phase I & BRII-196 & viral infection & human monoclonal antibody treatment & $\begin{array}{l}\text { Brii Biosciences, China; TSB Therapeutics } \\
\text { (Beijing) Co. Ltd., China }\end{array}$ \\
\hline 248 & Phase I & CK-0802 & $\begin{array}{l}\text { adult respiratory distress } \\
\text { syndrome }\end{array}$ & T lymphocyte replacement & Cellenkos Inc., USA \\
\hline 249 & Phase I & CT-P59 & viral infection & immunostimulant & Celltrion Inc., South Korea \\
\hline 250 & Phase I & Azvudine & AIDS & reverse transcriptase inhibitor & Chinese research sponsors, China \\
\hline 251 & Phase I & CPI-006 & cancer & 5-nucleotidase inhibitor & Corvus Pharmaceuticals Inc., USA \\
\hline 252 & Phase I (pending) & Cymerus & $\begin{array}{l}\text { asthma; cancer; } \\
\text { immunological disorders; } \\
\text { myocardial infarction; sepsis }\end{array}$ & cell replacement & Cynata Therapeutics Ltd., Australia \\
\hline 253 & Phase I & $\begin{array}{l}\text { Trans sodium } \\
\text { crocetinate }\end{array}$ & $\begin{array}{l}\text { brain metastases; } \\
\text { glioblastoma }\end{array}$ & oxygen compound modulator & $\begin{array}{l}\text { Diffusion Pharmaceuticals Inc., USA; } \\
\text { University of Virginia, USA }\end{array}$ \\
\hline 254 & Phase I & $\begin{array}{l}\text { Convalescent } \\
\text { Plasma; SARS-CoV- } \\
2 \text { specific T cells }\end{array}$ & viral infection & antibody treatment; immunotherapy & $\begin{array}{l}\text { Emory University, USA; University of } \\
\text { Southern California, USA; various } \\
\text { Singapore hospitals, Duke-NUS Graduate } \\
\text { Medical School, Singapore; University of } \\
\text { California, Los Angeles, USA }\end{array}$ \\
\hline 255 & Phase I & Bacteriotherapy & diarrhoea & $\begin{array}{l}\text { bacteria replacement; microbiome } \\
\text { modulator }\end{array}$ & Exegi Pharma LLC, USA \\
\hline 256 & Phase I & FSD-201 & $\begin{array}{l}\text { inflammation; pain; } \\
\text { fibromyalgia; irritable bowel } \\
\text { syndrome; neurological } \\
\text { disorders }\end{array}$ & $\begin{array}{l}\text { cannabinoid receptor agonist; G- } \\
\text { protein-coupled receptor } 55 \text { modulator; } \\
\text { peroxisome proliferator-activated } \\
\text { receptor alpha agonist }\end{array}$ & FSD Pharma Inc., Canada \\
\hline 257 & Phase I & IDB-003 & viral infection & monoclonal antibody-based treatment & Idbiologics Inc., USA \\
\hline 258 & Phase I & TJM-2 & rheumatoid arthritis & $\begin{array}{l}\text { granulocyte macrophage colony } \\
\text { stimulating factor antagonist }\end{array}$ & I-Mab Biopharma Co. Ltd., China \\
\hline 259 & Phase I & JS-016 & viral infection & coronavirus spike glycoprotein inhibitor & $\begin{array}{l}\text { Junshi Biosciences Ltd., China; Institute } \\
\text { of Microbiology of the Chinese Academy } \\
\text { of Sciences, China; Eli Lilly and Co., USA }\end{array}$ \\
\hline 260 & Phase I & $\begin{array}{l}\text { Proxalutamide (GT- } \\
\text { 0918) }\end{array}$ & $\begin{array}{l}\text { prostate cancer; breast } \\
\text { cancer }\end{array}$ & androgen receptor antagonist & Kintor Pharmaceutical Ltd., China \\
\hline 261 & Phase I & Amnioboost & osteoarthritis & processed amniotic fluid supplement & Lattice Biologics Ltd., USA \\
\hline 262 & Phase I & FT-516 & $\begin{array}{l}\text { acute myeloid leukaemia; } \\
\text { B-cell lymphoma; solid } \\
\text { tumor }\end{array}$ & $\begin{array}{l}\text { antibody-dependent cell cytotoxicity; } \\
\text { natural killer cell replacement }\end{array}$ & $\begin{array}{l}\text { Masonic Cancer Center, USA; University } \\
\text { of Minnesota, USA }\end{array}$ \\
\hline 263 & Phase I & MK-5475 & pulmonary hypertension & reduce pulmonary blood volume & Merck Sharp \& Dohme Corp., USA \\
\hline 264 & Phase I & TAK-981 & $\begin{array}{l}\text { non-Hodgkin's lymphoma; } \\
\text { solid tumor }\end{array}$ & $\begin{array}{l}\text { small ubiquitin-related modifier protein } \\
\text { inhibitor }\end{array}$ & $\begin{array}{l}\text { Millennium Pharmaceuticals Inc., USA; } \\
\text { Takeda, Japan }\end{array}$ \\
\hline 265 & Phase I & $\begin{array}{l}\text { CD-16; N-803; BM- } \\
\text { Allo.MSC } \\
\text { (mesenchymal stem } \\
\text { cells) }\end{array}$ & cancer; solid tumor & IL-15 receptor agonist; cell replacement & $\begin{array}{l}\text { Nantkwest Inc., USA; Immunitybio Inc., } \\
\text { USA }\end{array}$ \\
\hline 266 & Phase I & $\begin{array}{l}\text { NT-I7 (efineptakin } \\
\text { alfa) }\end{array}$ & $\begin{array}{l}\text { breast cancer; } \\
\text { glioblastoma; skin cancer; } \\
\text { solid tumour }\end{array}$ & $\begin{array}{l}\text { antibody-dependent cell cytotoxicity; } \\
\text { interleukin } 7 \text { replacement; T lymphocyte } \\
\text { stimulant }\end{array}$ & Neoimmunetech Inc., USA \\
\hline 267 & Phase I & Idronoxil (Veyonda) & cancer & induce tumor cell apoptosis & Noxopharm Co., Australia \\
\hline 268 & Phase I & PL-8177 & $\begin{array}{l}\text { inflammatory bowel } \\
\text { diseases; ulcerative colitis }\end{array}$ & melanocortin type 1 receptor agonist & Palatin Technologies Inc., USA \\
\hline 269 & Phase I & $\begin{array}{l}\text { LYT-100 } \\
\text { (deupirfenidone) }\end{array}$ & lymphoedema & collagen inhibitor; cytokine inhibitor & Puretech Health plc, USA \\
\hline 270 & Phase I & $\begin{array}{l}\text { Fostamatinib } \\
\text { (Tavalisse) }\end{array}$ & $\begin{array}{l}\text { idiopathic } \\
\text { thrombocytopenic purpura }\end{array}$ & syk kinase inhibitor & Rigel Pharmaceuticals Inc., USA \\
\hline 271 & Phase I & SAB-185 & viral infection & immunomodulator & $\begin{array}{l}\text { Sab Biotherapeutics, USA; U.S. } \\
\text { Department of Defense; CSL Behring } \\
\text { LLC, USA }\end{array}$ \\
\hline 272 & Phase I & SAR-443122 & $\begin{array}{l}\text { psoriasis; rheumatoid } \\
\text { arthritis }\end{array}$ & RIPK1 protein inhibitor & Sanofi, France \\
\hline 273 & Phase I & $\begin{array}{l}\text { STI-1499 (Covi- } \\
\text { Shield) }\end{array}$ & COVID-19 & block viral binding to receptor & Sorrento Therapeutics Inc., USA \\
\hline
\end{tabular}


TABLE 2 | Continued

\begin{tabular}{|c|c|c|c|c|c|}
\hline No. & Clinical stage & Drug name & Other disease targets & Mode of action & Organization/Company \\
\hline 274 & Phase I & $\begin{array}{l}\text { STI-4398 (Covi- } \\
\text { Shield) }\end{array}$ & COVID-19 & $\begin{array}{l}\text { ACE modulator; virus replication } \\
\text { inhibitor }\end{array}$ & $\begin{array}{l}\text { Sorrento Therapeutics Inc., USA; } \\
\text { University of Texas Medical Branch at } \\
\text { Galveston, USA; Mount Sinai Health } \\
\text { System, USA }\end{array}$ \\
\hline 275 & Phase I & TAK-671 & pancreatitis & immunomodulator; trypsin inhibitor & Takeda Pharmaceutical Co. Ltd., Japan \\
\hline 276 & Phase I & Gamma-delta T & cancer & immunotherapy & TC Biopharma Ltd., UK \\
\hline 277 & Phase I & Novaferon & $\begin{array}{l}\text { hepatitis B; neuroendocrine } \\
\text { tumour; cancer }\end{array}$ & interferon stimulants & Zhejiang University Medical School, China \\
\hline 278 & Phase I & TD-0903 & acute lung injury & janus kinase inhibitor & $\begin{array}{l}\text { Theravance Biopharma Inc., Cayman } \\
\text { Islands }\end{array}$ \\
\hline 279 & Phase I & TRV-027 & $\begin{array}{l}\text { heart failure; adult } \\
\text { respiratory distress } \\
\text { syndrome }\end{array}$ & $\begin{array}{l}\text { angiotensin type } 1 \text { receptor antagonist; } \\
\text { beta-arrestin stimulant }\end{array}$ & $\begin{array}{l}\text { Trevena Inc., USA; Imperial College } \\
\text { London, UK }\end{array}$ \\
\hline 280 & Phase I & $\begin{array}{l}\text { TY-027 (bifunctional } \\
\text { peptide derivative) }\end{array}$ & viral infection & virus internalisation inhibitor & Tychan Pte Ltd., Singapore \\
\hline 281 & Phase I & $\begin{array}{l}\text { Decidual stromal } \\
\text { cells }\end{array}$ & ARDS & reduce lung inflammation & $\begin{array}{l}\text { University Health Network, Canada; Oslo } \\
\text { University Hospital, Norway }\end{array}$ \\
\hline 282 & Phase I & Leflunomide & $\begin{array}{l}\text { psoriatic arthritis; } \\
\text { rheumatoid arthritis }\end{array}$ & inhibit dihydroorotate dehydrogenase & University of Chicago, USA \\
\hline 283 & Phase I & $\begin{array}{l}\text { Umbilical cord- } \\
\text { derived } \\
\text { mesenchymal stem } \\
\text { cells (intravenous) }\end{array}$ & graft-versus-host disease & cell replacement & $\begin{array}{l}\text { Wuhan Hamilton Biotechnology Co. Ltd., } \\
\text { China }\end{array}$ \\
\hline 284 & Phase I & Plasma treatment & COVID-19 & natural antibodies against COVID-19 & $\begin{array}{l}\text { Xbiotech Inc., USA; Biobridge Global, } \\
\text { USA }\end{array}$ \\
\hline
\end{tabular}

For further information visit the following links: https://clinicaltrials.gov, https://www.bioworld.com/COVID19products\#vac1 \& https://adisinsight.springer.com.

the COVID-19 treatment, ultimately, it has limited scope in controlling the outbreak at present.

\section{INTERFERON THERAPY}

\section{Therapeutics}

Type I interferons (IFN-I) stimulate the immune system upon viral infection by activating macrophages, natural killer cells, etc. and are expected to hinder SARS-CoV-2 infection (Samuel, 2001; Belhadi et al., 2020; Martinez, 2020). IFN-I is secreted by several cells when the pattern recognition receptors (PRRs) binds viral particles (Liu, 2005). IFN-I is recognized by the interferon- $\alpha / \beta$ receptor (IFNAR) in the plasma membrane. Upon binding of IFN-I, IFNAR induces the phosphorylation of several transcriptional factors, including STAT1. Once localized in the nucleus, STAT1 activates interferon-stimulated genes (ISGs), including PRRs, which further helps in decreasing membrane fluidity that inhibits viral entry through the membrane (Totura and Baric, 2012; Schneider et al., 2014). Although interferon treatment against SARS-CoV and MERS-CoV has shown variable efficiency (Stockman et al., 2006), the IFN $\beta$ subtype appears to work well in COVID-19 treatment if administered in the early stages of infection (Sallard et al., 2020). The side effects of interferon treatment could be toxic to a patient, especially when the patient is at critical stages of infection. Therefore, it is recommended to use this therapy in the early stages of infection.

\section{MEMBRANE FUSION INHIBITORS}

\section{Therapeutics}

Well-known antimalarial drugs chloroquine and its less toxic derivative hydroxychloroquine, both known to elevate the $\mathrm{pH}$ of endosomes/lysosomes that blocks membrane fusion and inhibits viral infection (Mauthe et al., 2018). Also, chloroquine found to impede glycosylation of the ACE2 receptor, which may inhibit the virus from receptor binding (Vincent et al., 2005). Both of these drugs helped inhibit this virus in the in vitro assays (Liu J. et al., 2020; Wang M. et al., 2020). However, some studies have raised concerns about the effectiveness of chloroquine/hydroxychloroquine in treating COVID-19 patients as these repurposed drugs were found to possess several side effects (Chary et al., 2020; Chen J. et al., 2020; Gautret et al., 2020; Kamp et al., 2020).

Current reports suggested that the influenza drug umifenovir is effective in reducing symptoms of COVID-19 (Zhang J. N. et al., 2020). Umifenovir (Arbidol) intercalates with the membrane lipids to inhibit the fusion between the virus particle and host membrane, which blocks the entrance point of the virus inside the host cell (Villalain, 2010; Blaising et al., 2014). Another influenza drug oseltamivir, which reduces infection in the respiratory system by blocking viral neuraminidase and inhibits viral particles from escaping host cells, was found to be effective in the COVID-19 outbreak in China (Uyeki, 2018; Wang D. et al., 2020).

Coronaviruses use several modes of endocytosis (clathrin- or caveolin-mediated, or by the formation of lipid rafts) depending on the virus and cell type, and therefore, blocking of the 
endocytic pathways could be a promising strategy for the development of antiviral drugs (Glebov, 2020; Yang and Shen, 2020). Several anti-endocytotic drugs (e.g., chlorpromazine, bafilomycin, etc.) that are known to inhibit clathrin-or caveolin-mediated endocytosis proposed to have therapeutic activities against coronaviruses including SARS-CoV-2 (Yang and Shen, 2020). In lung AT2, alveolar epithelial cells, AAK1 regulates endocytosis, and baricitinib inhibits AAK1 with high affinity. Therefore, researchers argue that baricitinib could be one of the potential drugs against COVID-19 (Richardson et al., 2020). However, others argue that baricitinib also inhibits the JAK-STAT mediated signaling pathway which affects the interferon-mediated immune response. It might have a fatal effect on COVID-19 patients (Favalli et al., 2020). Clinical trials are currently underway to find out whether the drug has any positive effect in treating COVID-19 patients.

\section{PROTEASE INHIBITORS}

\section{Human Protease Inhibitors (Therapeutics)}

Proprotein convertases (PCs) are essential for turning precursor proteins into their active forms, e.g., furin and other proteases that control viral host cell entry and infectivity (Yamada et al., 2018; Izaguirre, 2019). Host proteases cleaved the coronavirus $S$ proteins, including furin, TMPRSS2 (transmembrane protease serine protease 2), trypsin, cathepsin, etc., and the availability of these proteases in the infected cells are important for subsequent host cell entry (Ou et al., 2020). Furin or trypsin dependent proteolytic cleavage of the viral (SARS-CoV) S protein at two distinct sites was found to be essential for priming and subsequent membrane fusion with the host cell (Belouzard et al., 2009). MERS-CoV spike protein was also found to be activated by furin cleavage (Millet and Whittaker, 2014). Similarly, the S protein of SARS-CoV-2 has a putative cleavage site (furin) between S1 and S2 subunits, but whether it is cleaved during the priming event remains elusive (Ou et al., 2020). Another serine protease TMPRSS2 was found to be crucial for S protein priming in both SARS-CoV-2 and SARS-CoV (Matsuyama et al., 2010; Shulla et al., 2011; Iwata-Yoshikawa et al., 2019; Hoffmann et al., 2020). For SARS-CoV, it is the availability of specific proteases that appears to be the determinant factor to choose whether it enters the host cell via the cell surface or by using the endosomal cathepsin L-mediated pathway for viral entry. So, non-appearance of the host proteases within the cell surface, SARS$\mathrm{CoV}$ invade host cells though a pathway (endosomal pathway) where cathepsin L activates the spike protein, allowing the association of the viras particle and endosome membranes (Simmons et al., 2004; Kam et al., 2009; Chan et al., 2013).

Previous studies have shown that the dual treatment of an inhibitor of TMPRSS2- camostat mesylate and an inhibitor of cathepsin L efficiently blocked host cell entry of SARS-CoV. This competent inhibition could be attributed to the double barrier of entry for SARS-CoV from the surface of a cell and through the endosomal pathway (Kawase et al., 2012). Serine protease inhibitor camostat mesylate was found to block TMPRSS2-mediated priming of spike protein and inhibits COVID-19 infection in lung cells in vitro
(Hoffmann et al., 2020). Another TMPRSS2 inhibitor drug nafamostat mesylate was found to inhibit the membrane fusion of MERS-CoV and expected to have similar effects on this virus (Yamamoto et al., 2016; Hoffmann et al., 2020). These observations suggest that this protease inhibitor, camostat mesylate, and a cathepsin inhibitor can be used as antiviral drugs to prevent cathepsin L and TMPRSS2 -mediated SARS-CoV-2 infection.

One problem with using human protease inhibitors as antiviral drugs is that they might affect the normal physiological processes in the human cells, which may lead to further complications or side effects. Therefore, human protease inhibitors may be used in combinatorial therapies with other antiviral drugs which would allow using a less concentration of protease inhibitors to minimize side effects while keeping stronger efficacy. However, no human protease inhibitor has been approved as of now to use in treating viral infections despite having several experimental reports on their effectiveness as antiviral drugs (Steinmetzer and Hardes, 2018).

\section{Viral Protease Inhibitors (Therapeutics)}

In coronavirus, chymotrypsin-like protease $\left(3 \mathrm{CL}^{\text {pro }}\right.$ or $\left.\mathrm{M}^{\text {pro }}\right)$ is the main protease, and along with papain-like protease $\left(\mathrm{PL}^{\mathrm{pro}}\right)$ it processes the polyproteins pplab and ppla (Brierley et al., 1989; Gorbalenya et al., 2006). These two proteases are attractive targets for designing drugs to inhibit cleavage functions and render the virus non-functional (Anand et al., 2003; Yang et al., 2003; Ratia et al., 2008; Hilgenfeld, 2014; Arya et al., 2020; Wu C. et al., 2020). The structures of $\mathrm{M}^{\text {pro }}$ from SARS-CoV-2 and SARS-CoV are known. Hence, the designing of drugs to inhibit the protease has been accelerated (Xue et al., 2008; Zhang L. et al., 2020). An $\alpha$-ketoamide inhibitor has been identified that blocks SARS-CoV-2 $\mathrm{M}^{\text {pro }}$ from performing its functions shown in mice (Zhang L. et al., 2020). HIV protease inhibitor drug lopinavir/ritonavir was found to be useful in decreasing viral loads in COVID-19 patients (Lim et al., 2020). However, in clinical trials on COVID-19 patients, the HIV drug was found to be ineffective (Cao et al., 2020). Another HIV protease inhibitor darunavir is also under clinical trials to find out its efficacy in treating COVID-19 (Santos et al., 2019). In vitro studies have shown that several other antiretroviral protease inhibitors (e.g., nelfinavir, etc.) were highly effective in inhibiting coronaviruses (Yamamoto et al., 2004). However, the failure of Kaletra (lopinavir/ritonavir) has shown that protease inhibitors optimized for HIV are unlikely to be effective against SARS-CoV-2 as the proteases expressed by these two viruses are structurally different. Nonetheless, some efficacy against SARS-CoV-2 has been shown by HIV protease inhibitors under in vitro conditions and some of these inhibitors are also under various clinical trials to confirm their effectiveness against COVID-19 (Table 2). However, protease inhibitors specific for HIV protease (e.g., darunavir, etc.) are doubtful to be effective against SARS-CoV-2 protease because of the structural dissimilarities between them.

\section{REPLICASE INHIBITORS}

\section{Therapeutics}

Another attractive target for drug development is the SARSCoV-2 RNA-dependent RNA polymerase ( $\mathrm{RdRp})$, as this is the 
main molecule for the replication/transcription complex in coronaviruses. The cryo-EM structure of SARS-CoV-2 RdRp (nsp12) has been elucidated recently, along with cofactors nsp7 and nsp8 (Gao Y. et al., 2020). The structure derived using cryoEM methodology also explained how the drug remdesivir binds to the RdRp (Gao Y. et al., 2020). The nucleotide analog remdesivir has been shown to inhibit RdRp in SARS-CoV (Agostini et al., 2018; Saha et al., 2020a), MERS-CoV (Gordon et al., 2020), and SARS-CoV-2 (Holshue et al., 2020; Wang M. et al., 2020). In a recent study, remdesivir was found to provide benefit to the majority of COVID-19 patients who needed oxygen support (Grein et al., 2020). European Medicines Agency (EMA) has given conditional marketing approval to Veklury (remdesivir) for the therapy of critical COVID-19 patients (12 years of age or higher) with pneumonia and under oxygen support. Remdesivir is the first drug to get the required authorization to use in the EU for the treatment of COVID-19 (Table 2).

Other nucleotide/nucleoside analogs, e.g., sofosbuvir (Gane et al., 2013; Appleby et al., 2015; Ju et al., 2020), and ribavirin (Elfiky, 2020), were also found to be effective in inhibiting RdRp. Favipiravir, which has a structural similarity with nucleoside analogs, found to be effective in COVID-19 clinical trials (Chen C. et al., 2020). Another nucleoside analog galidesivir (BCX4430) was found effective in several infectious diseases, including Ebola, Zika, etc., and maybe useful in COVID-19, too (Taylor et al., 2016; Eyer et al., 2019). Similar antiviral drugs, triphosphate forms of AZT (3'-azido-3'-deoxythymidine triphosphate), and alovudine (3'-fluoro-3'-deoxythymidine triphosphate) were also predicted to inhibit SARS-CoV-2 RdRp (Ju et al., 2020). The guanosine analog ribavirin not only inhibits viral RdRp by directly interfering with it but also interferes with the RNA capping by inhibiting inosine monophosphate dehydrogenase enzyme to impede guanosine production in the host cell (Graci and Cameron, 2006; Khalili et al., 2020). Interestingly, antiparasitic drug ivermectin was found to suppress SARS-CoV-2 replication in cell culture efficiently (Caly et al., 2020). Ivermectin was predicted to inhibit the maturation of viral proteins by blocking IMP $\alpha / \beta 1$ mediated nuclear import (Wagstaff et al., 2012; Yang et al., 2020).

\section{NUCLEIC ACID-BASED SOLUTIONS}

\section{Vaccines}

The advantages of nucleic acid-based vaccines are that they can be quickly constructed and can induce strong cell-mediated and humoral immune responses even in the absence of an adjuvant (Du et al., 2009). During the Zika virus outbreak, DNA vaccines were the first to enter clinical trials (Prompetchara et al., 2020). A DNA vaccine is a new and innovative mode of vaccination involved in direct injection of a plasmid encoding the antigens (Shang et al., 2020). Certain advancements like the use of electroporation for delivering the plasmid and use of adjuvant further increases the efficacy by invoking better immune response. Several organizations are working for pre-clinical trials of DNA vaccines against COVID-19 (Liu, 2019) (Table 1). DNA vaccines against COVID-19 mainly encode different forms of the SARS-CoV-2 S protein that was found to stimulate both cellular and humoral immune responses in mice, guinea pigs, and rhesus macaques (Amanat and Krammer, 2020; Smith et al., 2020; Yu et al., 2020). However, there is a risk of integration and mutation of DNA vaccines within the host genome. Being safer, mRNA vaccines stand as a promising alternative to DNA and other conventional vaccine approaches because of its safety and quick development (Liu, 2019). So far, several organizations are working on developing an mRNA-based vaccine for SARS$\mathrm{CoV}-2$. Small interfering RNA (siRNA) based vaccines are also being developed targeting conserved regions on the SARS-CoV-2 genome, especially $3 \mathrm{CL}^{\text {pro }}$, $\mathrm{RdRp}$, and spike protein, to degrade viral mRNAs resulting inhibition of translation (Liu C. et al., 2020).

\section{Therapeutics}

Double-stranded RNA drug rintatolimod is now being tested for COVID-19, which stimulates the innate immune system by binding to one of the PRRs named TLR-3 found in the endosomal membrane. Once rintatolimod binds to TLR-3, the host cell gets a signal to produce interferons, which lead to various protective systems against pathogenic viruses or bacteria. Rintatolimod predicted to stimulate RNase L enzyme production, which degrades pathogenic RNAs of viruses (Gowen et al., 2007; Pardi et al., 2018).

\section{CONCLUSIONS}

There are several new vaccines and novel therapeutic molecules which are currently under development against COVID-19 (Tables 1 and 2). The finding of a safe and attractive target for vaccine development is of utmost importance at this point to prevent further spread of this virus. Unfortunately, the way SARS-CoV-2 is spreading around the world and infected cases increasing exponentially, we may have to witness much bigger devastation before a cure is found. Several promising drug targets have been identified, and several organizations are working relentlessly to develop vaccines against these targets (Table 1). Different available antiviral drugs (repurposed) are being tested for COVID-19 in large clinical trials, as they have shown some positive effects in initial phases (Table 2; Figure 1). Contradictory reports are also started to pouring in against some antiviral therapies targeted at COVID-19, where although initial reports suggested positive effects, later others showed no effect. For example, hydroxychloroquine treatment, along with azithromycin, has shown a significant reduction of viral load in COVID-19 infected patients (Gautret et al., 2020), but subsequent report refutes that claim and showed no benefit in severe COVID-19 patients by this treatment (Molina et al., 2020). Repurposing existing antiviral drugs against COVID-19 has shown some positive effects, but further scientific results are necessary to prove whether these affect COVID-19 treatment, or 
we are just looking at the placebo effect which can be dangerous for patients.

Recently, some unproven theories are spreading like wildfires, which may also hinder the actual progress on the vaccine development against COVID-19. One example is the use of the BCG vaccine, which is being advocated as a potential cure for COVID-19. Countries, where people have taken the antituberculosis Bacillus Calmette-Guerin (BCG) vaccine, appear to be immune from COVID-19 compared to countries where BCG vaccination is not a norm, as per some recent non-peerreviewed reports (Hegarty et al., 2020; Miller et al., 2020). Research organizations have already started clinical trials to test the efficacy of the BCG vaccine in COVID-19. It is not clear at this point how and whether BCG vaccination helps in preventing COVID-19 at all; therefore, further research is necessary to find the link between these two.

Several vaccine clinical and pre-clinical trials are currently ongoing (Table 1), and even if some trials finally become successful, a preventive vaccine may not be widely available for at least another 12-18 months. For a vaccine to be successful, much time is needed to conduct proper clinical trials, especially phase III and phase IV trials where the control group is large enough to get a conclusive report (Green, 2020). Therefore, fasttracking of any clinical trial could be potentially dangerous, and comprehensive safety tests are necessary before a vaccine can be marketed. It applies the same to any repurposed drugs that show positive effects in the initial phases of clinical trials. The catastrophic failure of the respiratory syncytial virus (RSV) vaccine in 1966 showed the importance of a proper clinical trial and advocating for fast-tracking any SARS-CoV-2 clinical trials should be avoided at this stage. The RSV vaccine failed due to the lack of antibody affinity maturation, the possibility of which should be thoroughly checked to avoid a similar situation in COVID-19 (Glezen et al., 1986).

Due to the high genome mutation rates in RNA viruses as the viral RNA polymerase (e.g., influenza virus) or reverse transcriptase (e.g., HIV) lacks proofreading activity, and therefore, it is difficult to make an effective vaccine against RNA viruses (Boutwell et al., 2010; Sanjuán et al., 2010). Although the excessive mutation rate in RNA viruses helps them to adapt quickly to the variable environmental conditions, it also makes them vulnerable because of the accumulation of lethal mutations in the essential genes. Interestingly, in SARS-CoV, the nsp14 protein found to contain an exoribonuclease domain (ExoN) that provides proofreading activity and the deletion of the gene results in a reduction of virulence (Hofer, 2013; Pachetti et al., 2020). This information is important as SARS-CoV-2 also contains a similar gene on its genome, and any proofreading activity would ensure low mutational rates during the synthesis of the viral genome, which would be helpful to design and to develop a vaccine candidate against the SARS-CoV-2 virus.

Coronaviruses are known for a long time and an extensive amount of knowledge has been gathered on SARS-CoV, despite that we still do not have a vaccine against it. We still do not have an effective vaccine against HIV or malaria, for example, although these pathogens are known to us for a long time
(Boutwell et al., 2010; Rts, 2015; King, 2019). Challenges posed by these pathogens are far more complex and require an extensive investigation that may take several years to complete. Therefore, extensive safety trials in humans with sizable groups of people are needed even if data from the initial phases are encouraging. Any rush at these stages may be catastrophic if upon vaccination to people who never exposed to the virus develop serious side effects.

Reports from the recent clinical trials of two COVID-19 vaccine candidates have shown promise as they were found to be safe for human use and also induced strong immune response against SARS-CoV-2 (Beyrer et al., 2012; Zhu et al., 2020). The vaccine AZD1222 (ChAdOx1 nCoV-19) developed jointly by Oxford University and AstraZeneca provides double protection against COVID-19 by producing both antibodies and T-cells that directly kill infected cells (Beyrer et al., 2012). Another vaccine (Ad5-nCOV) developed by CanSino Biologics, China, also shown to provide protection against SARS-CoV-2 (Zhu et al., 2020). These reports instill faith that a protective vaccine would be available soon to ease the suffering that the world is facing today because of COVID-19.

The virus has locked up several parts of the world from social and economic activities, and we have no other option but to wait for the development of a vaccine against COVID19. This situation was envisaged by several scientists earlier, but no one thought we have to witness this disaster in our lifetime. Humanity always prevailed under challenging conditions and the way many research organizations are trying to find a cure one can only hope that we could get a vaccine against COVID-19 sooner than later, but until then social distancing, rigorous testing, and isolation of infected persons in COVID-19 appears to be a potent strategy to contain the spread of the virus.

\section{AUTHOR CONTRIBUTIONS}

Writing-original draft: RS and ARS. Writing-review and editing: MKS, SS, SB, SM, and MB. Revising and supervising and funding acquisition: CC, ARS, and SSL.

\section{FUNDING}

This research was supported by Hallym University Research Fund and by Basic Science Research Program through the National Research Foundation of Korea (NRF) funded by the Ministry of Education (NRF-2017R1A2B4012944 \& NRF-2020R1C1C1008694).

\section{ACKNOWLEDGMENTS}

The authors are grateful to Adamas University management for their kind support. 


\section{REFERENCES}

Agostini, M. L., Andres, E. L., Sims, A. C., Graham, R. L., Sheahan, T. P., Lu, X., et al. (2018). Coronavirus susceptibility to the antiviral remdesivir (GS-5734) is mediated by the viral polymerase and the proofreading exoribonuclease. mBio 9, e00221-e00218. doi: 10.1128/mBio.00221-00218

Ahn, D.-G., Shin, H.-J., Kim, M.-H., Lee, S., Kim, H.-S., Myoung, J., et al. (2020). Current status of epidemiology, diagnosis, therapeutics, and vaccines for novel coronavirus disease 2019 (COVID-19). J. Microbiol. Biotechnol. 30 (3), 313324. doi: $10.4014 / \mathrm{jmb} .2003 .03011$

Amanat, F., and Krammer, F. (2020). SARS-CoV-2 vaccines: status report. Immunity 52 (4), 583-589. doi: 10.1016/j.immuni.2020.03.007

Anand, K., Ziebuhr, J., Wadhwani, P., Mesters, J. R., and Hilgenfeld, R. (2003). Coronavirus main proteinase (3CLpro) structure: basis for design of anti-SARS drugs. Science 300 (5626), 1763-1767. doi: 10.1126/science.1085658

Appleby, T. C., Perry, J. K., Murakami, E., Barauskas, O., Feng, J., Cho, A., et al. (2015). Structural basis for RNA replication by the hepatitis C virus polymerase. Science 347 (6223), 771-775. doi: 10.1126/science.1259210

Arbabi-Ghahroudi, M. (2017). Camelid single-domain antibodies: Historical perspective and future outlook. Front. Immunol. 8, 1589. doi: 10.3389/ fimmu.2017.01589

Arya, R., Das, A., Prashar, V., and Kumar, M. (2020). Potential inhibitors against papain-like protease of novel coronavirus (SARS-CoV-2) from FDA approved drugs. chemRxiv 1-8. doi: 10.26434/chemrxiv.11860011.v2

Assiri, A., McGeer, A., Perl, T. M., Price, C. S., Al Rabeeah, A. A., Cummings, D. A., et al. (2013). Hospital outbreak of Middle East respiratory syndrome coronavirus. New Engl. J. Med. 369 (5), 407-416. doi: 10.1056/NEJMoa1306742

Belhadi, D., Peiffer-Smadja, N., Lescure, F.-X., Yazdanpanah, Y., Mentré, F., and Laouénan, C. (2020). A brief review of antiviral drugs evaluated in registered clinical trials for COVID-19. medRxiv 2020.2003.2018.20038190. doi: 10.1101/ 2020.03.18.20038190

Belouzard, S., Chu, V. C., and Whittaker, G. R. (2009). Activation of the SARS coronavirus spike protein via sequential proteolytic cleavage at two distinct sites. Proc. Natl. Acad. Sci. 106 (14), 5871-5876. doi: 10.1073/pnas.0809524106

Beyrer, C., Baral, S. D., Van Griensven, F., Goodreau, S. M., Chariyalertsak, S., Wirtz, A. L., et al. (2012). Global epidemiology of HIV infection in men who have sex with men. Lancet 380 (9839), 367-377. doi: 10.1016/S0140-736(12) 60821-6

Bhattacharya, M., Sharma, A. R., Patra, P., Ghosh, P., Sharma, G., Patra, B. C., et al. (2020a). Development of epitope-based peptide vaccine against novel coronavirus 2019 (SARS-COV-2): Immunoinformatics approach. J. Med. Virol. 92 (6), 618-631. doi: 10.1002/jmv.25736

Bhattacharya, M., Sharma, A. R., Patra, P., Ghosh, P., Sharma, G., Patra, B. C., et al. (2020b). A SARS-CoV-2 vaccine candidate: In silico cloning and validation. Inf. Med. Unlocked 20, 100394. doi: 10.1016/j.imu.2020.100394

Blaising, J., Polyak, S. J., and Pécheur, E.-I. (2014). Arbidol as a broad-spectrum antiviral: an update. Antiviral Res. 107, 84-94. doi: 10.1016/ j.antiviral.2014.04.006

Bonavia, A., Zelus, B. D., Wentworth, D. E., Talbot, P. J., and Holmes, K. V. (2003). Identification of a receptor-binding domain of the spike glycoprotein of human coronavirus HCoV-229E. J. Virol. 77 (4), 2530-2538. doi: 10.1128/ jvi.77.4.2530-2538.2003

Bosch, B. J., van der Zee, R., de Haan, C. A., and Rottier, P. J. (2003). The coronavirus spike protein is a class I virus fusion protein: structural and functional characterization of the fusion core complex. J. Virol. 77 (16), 88018811. doi: 10.1128/JVI.77.16.8801-8811.2003

Boutwell, C. L., Rolland, M. M., Herbeck, J. T., Mullins, J. I., and Allen, T. M. (2010). Viral evolution and escape during acute HIV-1 infection. J. Infect. Dis. 202 (Suppl 2), S309. doi: 10.1086/655653

Brierley, I., Digard, P., and Inglis, S. C. (1989). Characterization of an efficient coronavirus ribosomal frameshifting signal: requirement for an RNA pseudoknot. Cell 57 (4), 537-547. doi: 10.1016/0092-8674(89)90124-4

Caly, L., Druce, J. D., Catton, M. G., Jans, D. A., and Wagstaff, K. M. (2020). The FDA-approved Drug Ivermectin inhibits the replication of SARS-CoV-2 in vitro. Antiviral Res. 178, 104787. doi: 10.1016/j.antiviral.2020.104787

Cao, B., Wang, Y., Wen, D., Liu, W., Wang, J., Fan, G., et al. (2020). A trial of lopinavir-ritonavir in adults hospitalized with severe Covid-19. New Engl. J. Med. 382 (19), 1787-1799. doi: 10.1056/NEJMoa2001282
Chakraborty, C., Sharma, A., Sharma, G., Bhattacharya, M., and And Lee, S. (2020a). SARS-CoV-2 causing pneumonia-associated respiratory disorder (COVID-19): diagnostic and proposed therapeutic options. Eur. Rev. Med. Pharmacol. Sci. 24, 4016-4026. doi: 10.26355/eurrev_202004_20871

Chakraborty, C., Sharma, A. R., Bhattacharya, M., Sharma, G., and Lee, S.-S. (2020b). The 2019 novel coronavirus disease (COVID-19) pandemic: A zoonotic prospective. Asian Pacific J. Trop. Med. 13 (6), 242. doi: 10.4103/ $1995-7645.281613$

Chakraborty, C., Sharma, A. R., Sharma, G., Saha, R. P., and Lee, S.-S. (2020c). Extensive partnership, collaboration, and teamwork is required to stop the COVID-19 outbreak. Arch. Med. Res. S0188-4409 (20), 30849-3. doi: 10.1016/ j.arcmed.2020.05.021

Chakraborty, C., Sharma, A. R., Bhattacharya, M., Sharma, G., Lee, S. S., and Agoramoorthy, G. (2020d). Consider TLR5 for new therapeutic development against COVID-19. J. Med. Virol. doi: 10.1002/jmv.25997

Chakraborty, C., Sharma, A. R., Bhattacharya, M., Sharma, G., Lee, S. S., and Agoramoorthy, G. (2020e). COVID-19: Consider IL6 receptor antagonist for the therapy of cytokine storm syndrome in SARS-CoV-2 infected patients. J. Med. Virol. doi: 10.1002/jmv.26078

Chan, J. F.-W., To, K. K.-W., Tse, H., Jin, D.-Y., and Yuen, K.-Y. (2013). Interspecies transmission and emergence of novel viruses: lessons from bats and birds. Trends Microbiol. 21 (10), 544-555. doi: 10.1016/j.tim.2013.05.005

Chan, J. F.-W., Kok, K.-H., Zhu, Z., Chu, H., To, K. K.-W., Yuan, S., et al. (2020a). Genomic characterization of the 2019 novel human-pathogenic coronavirus isolated from a patient with atypical pneumonia after visiting Wuhan. Emerg. Microbes Infect. 9 (1), 221-236. doi: 10.1080/22221751.2020.1719902

Chan, J. F.-W., Yuan, S., Kok, K.-H., To, K. K.-W., Chu, H., Yang, J., et al. (2020b). A familial cluster of pneumonia associated with the 2019 novel coronavirus indicating person-to-person transmission: a study of a family cluster. Lancet 395 (10223), 514-523. doi: 10.1016/S0140-6736(20)30154-9

Chary, M. A., Barbuto, A. F., Izadmehr, S., Hayes, B. D., and Burns, M. M. (2020). COVID-19: Therapeutics and their toxicities. J. Med. Toxicol. 16 (3), 10.1007. doi: 10.1007/s13181-020-00777-5

Chen, Z., Bao, L., Chen, C., Zou, T., Xue, Y., Li, F., et al. (2017). Human neutralizing monoclonal antibody inhibition of middle east respiratory syndrome coronavirus replication in the common marmoset. J. Infect. Dis. 215 (12), 1807-1815. doi: 10.1093/infdis/jix209

Chen, C., Huang, J., Cheng, Z., Wu, J., Chen, S., Zhang, Y., et al. (2020). Favipiravir versus Arbidol for COVID-19: a randomized clinical trial. MedRxiv. 1-29. doi: 10.1101/2020.03.17.20037432

Chen, J., Liu, D., Liu, L., Liu, P., Xu, Q., Xia, L., et al. (2020). A pilot study of hydroxychloroquine in treatment of patients with common coronavirus disease-19 (COVID-19). J. Zhejiang Univ. (Med. Sci.) 49 (1), 0-0. doi: 10.3785/j.issn.1008-9292.2020.03.03

Chen, W.-H., Strych, U., Hotez, P. J., and Bottazzi, M. E. (2020). The SARS-CoV-2 vaccine pipeline: an overview. Curr. Trop. Med. Rep. 7, 1-4. doi: 10.1007/ s40475-020-00201-6

Crotty, S. (2014). T follicular helper cell differentiation, function, and roles in disease. Immunity 41 (4), 529-542. doi: 10.1016/j.immuni.2014.10.004

Darnell, J. E., Kerr, I. M., and Stark, G. R. (1994). Jak-STAT pathways and transcriptional activation in response to IFNs and other extracellular signaling proteins. Science 264 (5164), 1415-1421. doi: 10.1126/science.8197455

de Wilde, A. H., Snijder, E. J., Kikkert, M., and van Hemert, M. J. (2017). "Host factors in coronavirus replication" in Roles of Host Gene and Non-coding RNA Expression in Virus Infection (Cham, Switzerland: Springer), 1-42.

Diaz, J. H. (2020). Hypothesis: angiotensin-converting enzyme inhibitors and angiotensin receptor blockers may increase the risk of severe COVID-19. J. Travel Med. 27 (3), (1-2). doi: 10.1093/jtm/taaa041

Du, L., He, Y., Zhou, Y., Liu, S., Zheng, B.-J., and Jiang, S. (2009). The spike protein of SARS-CoV-a target for vaccine and therapeutic development. Nat. Rev. Microbiol. 7 (3), 226-236. doi: 10.1038/nrmicro2090

Du, L., Kou, Z., Ma, C., Tao, X., Wang, L., Zhao, G., et al. (2013a). A truncated receptor-binding domain of MERS-CoV spike protein potently inhibits MERS$\mathrm{CoV}$ infection and induces strong neutralizing antibody responses: implication for developing therapeutics and vaccines. PloS One 8 (12), e81587. doi: 10.1371/journal.pone.0081587

Du, L., Zhao, G., Kou, Z., Ma, C., Sun, S., Poon, V. K., et al. (2013b). Identification of a receptor-binding domain in the $S$ protein of the novel human coronavirus 
Middle East respiratory syndrome coronavirus as an essential target for vaccine development. J. Virol. 87 (17), 9939-9942. doi: 10.1128/JVI.01048-13

Duan, K., Liu, B., Li, C., Zhang, H., Yu, T., Qu, J., et al. (2020). Effectiveness of convalescent plasma therapy in severe COVID-19 patients. Proc. Natl. Acad. Sci. U.S.A. 117 (17), 9490-9496. doi: 10.1073/pnas.2004168117

Elfiky, A. A. (2020). Anti-HCV, nucleotide inhibitors, repurposing against COVID-19. Life Sci. 248, 117477. doi: 10.1016/j.lfs.2020.117477

Epelman, S., Tang, W. W., Chen, S. Y., Van Lente, F., Francis, G. S., and Sen, S. (2008). Detection of soluble angiotensin-converting enzyme 2 in heart failure: insights into the endogenous counter-regulatory pathway of the reninangiotensin-aldosterone system. J. Am. Coll. Cardiol. 52 (9), 750-754. doi: 10.1016/j.jacc.2008.02.088

Epelman, S., Shrestha, K., Troughton, R. W., Francis, G. S., Sen, S., Klein, A. L., et al. (2009). Soluble angiotensin-converting enzyme 2 in human heart failure: relation with myocardial function and clinical outcomes. J. Cardiac Failure 15 (7), 565-571. doi: 10.1016/j.cardfail.2009.01.014

Eyer, L., Nougairède, A., Uhlírová, M., Driouich, J.-S., Zouharová, D., Valdés, J. J., et al. (2019). An E460D substitution in the NS5 protein of tick-borne encephalitis virus confers resistance to the inhibitor Galidesivir (BCX4430) and also attenuates the virus for mice. J. Virol. 93 (16), e00367-e00319. doi: 10.1128/JVI.00367-19

Favalli, E. G., Biggioggero, M., Maioli, G., and Caporali, R. (2020). Baricitinib for COVID-19: a suitable treatment? Lancet Infect. Dis. doi: 10.1016/S1473-3099 (20)30262-0

Fehr, A. R., and Perlman, S. (2015). "Coronaviruses: an overview of their replication and pathogenesis" in Coronaviruses (New York, NY: Springer), $1-23$.

Gane, E. J., Stedman, C. A., Hyland, R. H., Ding, X., Svarovskaia, E., Symonds, W. T., et al. (2013). Nucleotide polymerase inhibitor sofosbuvir plus ribavirin for hepatitis C. New Engl. J. Med. 368 (1), 34-44. doi: 10.1056/NEJMoa1208953

Gao, Q., Bao, L., Mao, H., Wang, L., Xu, K., Li, Y., et al. (2020). Rapid development of an inactivated vaccine for SARS-CoV-2. BioRxiv 1-29. doi: 10.1101/ 2020.04.17.046375

Gao, Y., Yan, L., Huang, Y., Liu, F., Zhao, Y., Cao, L., et al. (2020). Structure of the RNA-dependent RNA polymerase from COVID-19 virus. Science 368 (6492), 779-782. doi: 10.1126/science.abb7498

Gautret, P., Lagier, J.-C., Parola, P., Meddeb, L., Mailhe, M., Doudier, B., et al. (2020). Hydroxychloroquine and azithromycin as a treatment of COVID-19: results of an open-label non-randomized clinical trial. Int. J. Antimicrob. Agents 56 (1), 105949. doi: 10.1016/j.ijantimicag.2020.105949

Ge, X.-Y., Li, J.-L., Yang, X.-L., Chmura, A. A., Zhu, G., Epstein, J. H., et al. (2013). Isolation and characterization of a bat SARS-like coronavirus that uses the ACE2 receptor. Nature 503 (7477), 535-538. doi: 10.1038/nature12711

Glebov, O. O. (2020). Understanding SARS-CoV-2 endocytosis for COVID-19 drug repurposing. FEBS J. doi: 10.1111/febs.15369

Glezen, W. P., Taber, L. H., Frank, A. L., and Kasel, J. A. (1986). Risk of primary infection and reinfection with respiratory syncytial virus. Am. J. Dis. Children 140 (6), 543-546. doi: 10.1001/archpedi.1986.02140200053026

Godet, M., Grosclaude, J., Delmas, B., and Laude, H. (1994). Major receptorbinding and neutralization determinants are located within the same domain of the transmissible gastroenteritis virus (coronavirus) spike protein. J. Virol. 68 (12), 8008-8016. doi: 10.1128/JVI.68.12.8008-8016.1994

González-Navajas, J. M., Lee, J., David, M., and Raz, E. (2012). Immunomodulatory functions of type I interferons. Nat. Rev. Immunol. 12 (2), 125-135. doi: 10.1038/nri3133

Gorbalenya, A. E., Enjuanes, L., Ziebuhr, J., and Snijder, E. J. (2006). Nidovirales: evolving the largest RNA virus genome. Virus Res. 117 (1), 17-37. doi: 10.1016/ j.virusres.2006.01.017

Gorbalenya, A. E. (2020). Severe acute respiratory syndrome-related coronavirusThe species and its viruses, a statement of the Coronavirus Study Group. BioRxiv 117 (1), 17-37. doi: 10.1101/2020.02.07.937862

Gordon, C. J., Tchesnokov, E. P., Feng, J. Y., Porter, D. P., and Götte, M. (2020). The antiviral compound remdesivir potently inhibits RNA-dependent RNA polymerase from Middle East respiratory syndrome coronavirus. J. Biol. Chem. 295 (15), 4773-4779. doi: 10.1074/jbc.AC120.013056

Gowen, B. B., Wong, M.-H., Jung, K.-H., Sanders, A. B., Mitchell, W. M., Alexopoulou, L., et al. (2007). TLR3 is essential for the induction of protective immunity against Punta Toro Virus infection by the double- stranded RNA (dsRNA), poly (I: C12U), but not Poly (I: C): differential recognition of synthetic dsRNA molecules. J. Immunol. 178 (8), 5200-5208. doi: 10.4049 /jimmunol.178.8.5200

Graci, J. D., and Cameron, C. E. (2006). Mechanisms of action of ribavirin against distinct viruses. Rev. Med. Virol. 16 (1), 37-48. doi: 10.1002/rmv.483

Green, D. R. (2020). SARS-CoV2 vaccines: Slow is fast (Washington, D.C., United States: American Association for the Advancement of Science).

Grein, J., Ohmagari, N., Shin, D., Diaz, G., Asperges, E., Castagna, A., et al. (2020). Compassionate Use of Remdesivir for Patients with Severe Covid-19. N Engl. J. Med. 382 (24), 2327-2336. doi: 10.1056/NEJMoa2007016

Gu, H., Xie, Z., Li, T., Zhang, S., Lai, C., Zhu, P., et al. (2016). Angiotensinconverting enzyme 2 inhibits lung injury induced by respiratory syncytial virus. Sci. Rep. 6, 19840. doi: 10.1038/srep19840

Halstead, S. B. (2017). Dengvaxia sensitizes seronegatives to vaccine enhanced disease regardless of age. Vaccine 35 (47), 6355-6358. doi: 10.1016/ j.vaccine.2017.09.089

Hashimoto, T., Perlot, T., Rehman, A., Trichereau, J., Ishiguro, H., Paolino, M., et al. (2012). ACE2 links amino acid malnutrition to microbial ecology and intestinal inflammation. Nature 487 (7408), 477-481. doi: 10.1038/ nature 11228

He, Y., Zhou, Y., Siddiqui, P., and Jiang, S. (2004). Inactivated SARS-CoV vaccine elicits high titers of spike protein-specific antibodies that block receptor binding and virus entry. Biochem. Biophys. Res. Commun. 325 (2), 445-452. doi: 10.1016/j.bbrc.2004.10.052

He, Y., Zhu, Q., Liu, S., Zhou, Y., Yang, B., Li, J., et al. (2005). Identification of a critical neutralization determinant of severe acute respiratory syndrome (SARS)-associated coronavirus: importance for designing SARS vaccines. Virology 334 (1), 74-82. doi: 10.1016/j.virol.2005.01.034

Hegarty, P. K., Kamat, A. M., Zafirakis, H., and Dinardo, A. (2020). BCG vaccination may be protective against Covid-19. Preprint doi: 10.13140/ RG.2.2.35948.10880

Hilgenfeld, R. (2014). From SARS to MERS: crystallographic studies on coronaviral proteases enable antiviral drug design. FEBS J. 281 (18), 40854096. doi: 10.1111 /febs.12936

Hofer, U. (2013). Viral evolution: fooling the coronavirus proofreading machinery. Nat. Rev. Microbiol. 11 (10), 662. doi: 10.1038/nrmicro3125

Hoffmann, M., Hofmann-Winkler, H., and Pöhlmann, S. (2018). "Priming time: How cellular proteases arm coronavirus spike proteins," in Activation of Viruses by Host Proteases (Cham, Switzerland: Springer), 71-98.

Hoffmann, M., Kleine-Weber, H., Schroeder, S., Krüger, N., Herrler, T., Erichsen, S., et al. (2020). SARS-CoV-2 cell entry depends on ACE2 and TMPRSS2 and is blocked by a clinically proven protease inhibitor. Cell 181 (2), 271-280.e8. doi: 10.1016/j.cell.2020.02.052

Hofmann, H., Pyrc, K., van der Hoek, L., Geier, M., Berkhout, B., and Pöhlmann, S. (2005). Human coronavirus NL63 employs the severe acute respiratory syndrome coronavirus receptor for cellular entry. Proc. Natl. Acad. Sci. 102 (22), 7988-7993. doi: 10.1073/pnas.0409465102

Holshue, M. L., DeBolt, C., Lindquist, S., Lofy, K. H., Wiesman, J., Bruce, H., et al. (2020). First case of 2019 novel coronavirus in the United States. New Engl. J. Med. 382 (10), 929-936. doi: 10.1056/NEJMoa2001191

Huang, X., Dong, W., Milewska, A., Golda, A., Qi, Y., Zhu, Q. K., et al. (2015). Human coronavirus HKU1 spike protein uses O-acetylated sialic acid as an attachment receptor determinant and employs hemagglutinin-esterase protein as a receptor-destroying enzyme. J. Virol. 89 (14), 7202-7213. doi: 10.1128/ JVI.00854-15

Huang, C., Wang, Y., Li, X., Ren, L., Zhao, J., Hu, Y., et al. (2020). Clinical features of patients infected with 2019 novel coronavirus in Wuhan, China. Lancet 395 (10223), 497-506. doi: 10.1016/S0140-6736(20)30183-5

Iwata-Yoshikawa, N., Okamura, T., Shimizu, Y., Hasegawa, H., Takeda, M., and Nagata, N. (2019). TMPRSS2 contributes to virus spread and immunopathology in the airways of murine models after coronavirus infection. J. Virol. 93 (6), e01815-e01818. doi: 10.1128/JVI.01815-18

Izaguirre, G. (2019). The Proteolytic Regulation of Virus Cell Entry by Furin and Other Proprotein Convertases. Viruses 11 (9), 837. doi: 10.3390/v11090837

Jiang, S., He, Y., and Liu, S. (2005). SARS vaccine development. Emerg. Infect. Dis. 11 (7), 1016-1020. doi: 10.3201/1107.050219

Jiang, S., Bottazzi, M. E., Du, L., Lustigman, S., Tseng, C.-T. K., Curti, E., et al. (2012). Roadmap to developing a recombinant coronavirus $\mathrm{S}$ protein receptor- 
binding domain vaccine for severe acute respiratory syndrome. Expert Rev. Vacc. 11 (12), 1405-1413. doi: 10.1586/erv.12.126

Jiang, F., Yang, J., Zhang, Y., Dong, M., Wang, S., Zhang, Q., et al. (2014). Angiotensin-converting enzyme 2 and angiotensin 1-7: novel therapeutic targets. Nat. Rev. Cardiol. 11 (7), 413. doi: 10.1038/nrcardio.2014.59

Jiang, S., Hillyer, C., and Du, L. (2020). Neutralizing Antibodies against SARSCoV-2 and Other Human Coronaviruses. Trends Immunol. 41 (5), 355-359. doi: $10.1016 /$ j.it.2020.03.007

Ju, J., Li, X., Kumar, S., Jockusch, S., Chien, M., Tao, C., et al. (2020). Nucleotide Analogues as Inhibitors of SARS-CoV Polymerase. BioRxiv 1-8. doi: 10.1101/ 2020.03.12.989186

Kam, Y. W., Okumura, Y., Kido, H., Ng, L. F., Bruzzone, R., and Altmeyer, R. (2009). Cleavage of the SARS coronavirus spike glycoprotein by airway proteases enhances virus entry into human bronchial epithelial cells in vitro. PloS One 4 (11), e7870. doi: 10.1371/journal.pone.0007870

Kamp, T. J., Hamdan, M. H., and January, C. T. (2020). Chloroquine or Hydroxychloroquine for COVID-19: Is Cardiotoxicity a Concern? J. Am. Heart Assoc. 9 (12), e016887. doi: 10.1161/JAHA.120.016887

Kane, M., Zang, T. M., Rihn, S. J., Zhang, F., Kueck, T., Alim, M., et al. (2016). Identification of interferon-stimulated genes with antiretroviral activity. Cell Host Microbe 20 (3), 392-405. doi: 10.1016/j.chom.2016.08.005

Kang, T. H., and Jung, S. T. (2019). Boosting therapeutic potency of antibodies by taming Fc domain functions. Exp. Mol. Med. 51 (11), 1-9. doi: 10.1038/s12276019-0345-9

Kang, S., Yang, M., Hong, Z., Zhang, L., Huang, Z., Chen, X., et al. (2020). Crystal structure of SARS-CoV-2 nucleocapsid protein RNA binding domain reveals potential unique drug targeting sites. BioRxiv 2020, 2003.2006.977876. doi: 10.1101/2020.03.06.977876

Katze, M. G., He, Y., and Gale, M. (2002). Viruses and interferon: a fight for supremacy. Nat. Rev. Immunol. 2 (9), 675-687. doi: 10.1038/nri888

Kawase, M., Shirato, K., van der Hoek, L., Taguchi, F., and Matsuyama, S. (2012). Simultaneous treatment of human bronchial epithelial cells with serine and cysteine protease inhibitors prevents severe acute respiratory syndrome coronavirus entry. J. Virol. 86 (12), 6537-6545. doi: 10.1128/JVI.00094-12

Keller, M., Kitsis, E., Arora, S., Chen, J.-T., Agarwal, S., Ross, M., et al. (2020). Effect of Systemic Glucocorticoids on Mortality or Mechanical Ventilation in Patients With COVID-19. J. Hosp. Med. 8, 489-493. doi: 10.12788/ jhm.3497

Khalili, J. S., Zhu, H., Mak, A., Yan, Y., and Zhu, Y. (2020). Novel coronavirus treatment with ribavirin: Groundwork for evaluation concerning COVID-19. J. Med. Virol. 92 (7), 740-746. doi: 10.1002/jmv.25798

Khan, N., Gowthaman, U., Pahari, S., and Agrewala, J. N. (2012). Manipulation of costimulatory molecules by intracellular pathogens: veni, vidi, vici!! PloS Pathog. 8 (6), e1002676. doi: 10.1371/journal.ppat.1002676

King, A. (2019). Building a better malaria vaccine. Nature 575 (7784), S51. doi: 10.1038/d41586-019-03639-5

Klimpel, G. R. (1996). "Immune defenses," in Medical Microbiology, 4th edition (Texas, United States: University of Texas Medical Branch at Galveston).

Kopecky-Bromberg, S. A., Martínez-Sobrido, L., Frieman, M., Baric, R. A., and Palese, P. (2007). Severe acute respiratory syndrome coronavirus open reading frame (ORF) 3b, ORF 6, and nucleocapsid proteins function as interferon antagonists. J. Virol. 81 (2), 548-557. doi: 10.1128/JVI.01782-06

Kraft, C. S., Hewlett, A. L., Koepsell, S., Winkler, A. M., Kratochvil, C. J., Larson, L., et al. (2015). The use of TKM-100802 and Convalescent Plasma in 2 patients with ebola virus disease in the United States. Clin. Infect. Dis. 61 (4), 496-502. doi: $10.1093 / \mathrm{cid} / \mathrm{civ} 334$

Krempl, C., Schultze, B., and Herrler, G. (1995). "Analysis of cellular receptors for human coronavirus OC43," in Corona-and Related Viruses (Boston, MA: Springer), 371-374.

Kuba, K., Imai, Y., Rao, S., Gao, H., Guo, F., Guan, B., et al. (2005). A crucial role of angiotensin converting enzyme 2 (ACE2) in SARS coronavirus-induced lung injury. Nat. Med. 11 (8), 875-879. doi: 10.1038/nm1267

Kubo, H., Yamada, Y. K., and Taguchi, F. (1994). Localization of neutralizing epitopes and the receptor-binding site within the amino-terminal 330 amino acids of the murine coronavirus spike protein. J. Virol. 68 (9), 5403-5410. doi: 10.1128/JVI.68.9.5403-5410.1994

Lamb, Y. N., and Deeks, E. D. (2018). Sarilumab: a review in moderate to severe rheumatoid arthritis. Drugs 78 (9), 929-940. doi: 10.1007/s40265-018-0929-Z
Lan, J., Ge, J., Yu, J., Shan, S., Zhou, H., Fan, S., et al. (2020). Structure of the SARSCoV-2 spike receptor-binding domain bound to the ACE2 receptor. Nature 581 (7807), 1-9. doi: 10.1038/s41586-020-2180-5

Lauer, S. A., Grantz, K. H., Bi, Q., Jones, F. K., Zheng, Q., Meredith, H. R., et al. (2020). The incubation period of coronavirus disease 2019 (COVID-19) from publicly reported confirmed cases: estimation and application. Ann. Internal Med. 172 (9), 577-582. doi: 10.7326/M20-0504

Lee, N., Chan, K. A., Hui, D. S., Ng, E. K., Wu, A., Chiu, R. W., et al. (2004). Effects of early corticosteroid treatment on plasma SARS-associated Coronavirus RNA concentrations in adult patients. J. Clin. Virol. 31 (4), 304-309. doi: 10.1016/j.jcv.2004.07.006

Levy, D. E., and Darnell, J. (2002). Stats: transcriptional control and biological impact. Nat. Rev. Mol. Cell Biol. 3 (9), 651-662. doi: 10.1038/nrm909

Li, W., Moore, M. J., Vasilieva, N., Sui, J., Wong, S. K., Berne, M. A., et al. (2003). Angiotensin-converting enzyme 2 is a functional receptor for the SARS coronavirus. Nature 426 (6965), 450-454. doi: 10.1038/nature02145

Li, Z., Palaniyandi, S., Zeng, R., Tuo, W., Roopenian, D. C., and Zhu, X. (2011). Transfer of IgG in the female genital tract by MHC class I-related neonatal Fc receptor $(\mathrm{FcRn})$ confers protective immunity to vaginal infection. Proc. Natl. Acad. Sci. 108 (11), 4388-4393. doi: 10.1073/pnas.1012861108

Li, G., Hu, R., and Zhang, X. (2020). Antihypertensive treatment with ACEI/ARB of patients with COVID-19 complicated by hypertension. Hypertension Res. 43 (6), 1-3. doi: 10.1038/s41440-020-0433-1

Lim, J., Jeon, S., Shin, H.-Y., Kim, M. J., Seong, Y. M., Lee, W. J., et al. (2020). Case of the index patient who caused tertiary transmission of COVID-19 infection in Korea: the application of lopinavir/ritonavir for the treatment of COVID-19 infected pneumonia monitored by quantitative RT-PCR. J. Korean Med. Sci. 35 (6), 1-6. doi: 10.3346/jkms.2020.35.e79

Liu, Y., Zhang, Z., Zhao, X., Yu, R., Zhang, X., Wu, S., et al. (2014). Enterovirus 71 inhibits cellular type I interferon signaling by downregulating JAK1 protein expression. Viral Immunol. 27 (6), 267-276. doi: 10.1089/vim.2013.0127

Liu, L., Wei, Q., Lin, Q., Fang, J., Wang, H., Kwok, H., et al. (2019). Anti-spike IgG causes severe acute lung injury by skewing macrophage responses during acute SARS-CoV infection. JCI Insight 4 (4), 1-20. doi: 10.1172/jci.insight.123158

Liu, C., Zhou, Q., Li, Y., Garner, L. V., Watkins, S. P., Carter, L. J., et al. (2020). Research and development on therapeutic agents and vaccines for COVID-19 and related human coronavirus diseases (Washington, D.C., United States: ACS Publications).

Liu, J., Cao, R., Xu, M., Wang, X., Zhang, H., Hu, H., et al. (2020). Hydroxychloroquine, a less toxic derivative of chloroquine, is effective in inhibiting SARS-CoV-2 infection in vitro. Cell Discovery 6, 16. doi: 10.1038/ s41421-020-0156-0

Liu, Y., Gayle, A. A., Wilder-Smith, A., and Rocklöv, J. (2020). The reproductive number of COVID-19 is higher compared to SARS coronavirus. J. Travel Med. 27 (2), taaa021. doi: 10.1093/jtm/taaa021

Liu, Y. J. (2005). IPC: professional type 1 interferon-producing cells and plasmacytoid dendritic cell precursors. Annu. Rev. Immunol. 23, 275-306. doi: 10.1146/annurev.immunol.23.021704.115633

Liu, M. A. (2019). A comparison of plasmid DNA and mrna as vaccine technologies. Vaccines 7 (2), 37. doi: 10.3390/vaccines 7020037

Lu, X., Pan, J. A., Tao, J., and Guo, D. (2011). SARS-CoV nucleocapsid protein antagonizes IFN $-\beta$ response by targeting initial step of IFN- $\beta$ induction pathway, and its C-terminal region is critical for the antagonism. Virus Genes 42 (1), 37-45. doi: 10.1007/s11262-010-0544-x

Lu, R., Zhao, X., Li, J., Niu, P., Yang, B., Wu, H., et al. (2020). Genomic characterisation and epidemiology of 2019 novel coronavirus: implications for virus origins and receptor binding. Lancet 395 (10224), 565-574. doi: 10.1016/S0140-6736(20)30251-8

Luo, F., Liao, F.-L., Wang, H., Tang, H.-B., Yang, Z.-Q., and Hou, W. (2018). Evaluation of antibody-dependent enhancement of SARS-CoV infection in rhesus macaques immunized with an inactivated SARS-CoV vaccine. Virol. Sin. 33 (2), 201-204. doi: 10.1007/s12250-018-0009-2

Luo, P., Liu, Y., Qiu, L., Liu, X., Liu, D., and Li, J. (2020). Tocilizumab treatment in COVID-19: A single center experience. J. Med. Virol. 92 (7), 814-818. doi: $10.1002 / j m v .25801$

Magro, G. (2020). SARS-CoV-2 and COVID-19: is interleukin-6 (IL-6) the'culprit lesion' of ARDS onset? What is there besides Tocilizumab? SGP130Fc. Cytokine: X 2 (2), 100029. doi: 10.1016/j.cytox.2020.100029 
Mahallawi, W. H., Khabour, O. F., Zhang, Q., Makhdoum, H. M., and Suliman, B. A. (2018). MERS-CoV infection in humans is associated with a pro-inflammatory Th1 and Th17 cytokine profile. Cytokine 104, 8-13. doi: 10.1016/j.cyto.2018.01.025

Marano, G., Vaglio, S., Pupella, S., Facco, G., Catalano, L., Liumbruno, G. M., et al. (2016). Convalescent plasma: new evidence for an old therapeutic tool? Blood Transfus. 14 (2), 152-157. doi: 10.2450/2015.0131-15

Martinez, M. A. (2020). Compounds with Therapeutic Potential against Novel Respiratory 2019 Coronavirus. Antimicrob. Agents Chemother. 64 (5), e0039920. doi: 10.1128/AAC.00399-20

Matsuyama, S., Nagata, N., Shirato, K., Kawase, M., Takeda, M., and Taguchi, F. (2010). Efficient activation of the severe acute respiratory syndrome coronavirus spike protein by the transmembrane protease TMPRSS2. J. Virol. 84 (24), 12658-12664. doi: 10.1128/JVI.01542-10

Mauthe, M., Orhon, I., Rocchi, C., Zhou, X., Luhr, M., Hijlkema, K. J., et al. (2018). Chloroquine inhibits autophagic flux by decreasing autophagosome-lysosome fusion. Autophagy 14 (8), 1435-1455. doi: 10.1080/15548627.2018.1474314

Miller, A., Reandelar, M. J., Fasciglione, K., Roumenova, V., Li, Y., and Otazu, G. H. (2020). Correlation between universal BCG vaccination policy and reduced morbidity and mortality for COVID-19: an epidemiological study. MedRxiv 1-9. doi: 10.1101/2020.03.24.20042937

Millet, J. K., and Whittaker, G. R. (2014). Host cell entry of Middle East respiratory syndrome coronavirus after two-step, furin-mediated activation of the spike protein. Proc. Natl. Acad. Sci. 111 (42), 15214-15219. doi: 10.1073/ pnas. 1407087111

Mire, C. E., Geisbert, J. B., Agans, K. N., Thi, E. P., Lee, A. C., Fenton, K. A., et al. (2016). Passive Immunotherapy: Assessment of Convalescent Serum Against Ebola Virus Makona Infection in Nonhuman Primates. J. Infect. Dis. 214 (suppl 3), S367-S374. doi: 10.1093/infdis/jiw333

Molina, J. M., Delaugerre, C., Goff, J., Mela-Lima, B., Ponscarme, D., Goldwirt, L., et al. (2020). No evidence of rapid antiviral clearance or clinical benefit with the combination of hydroxychloroquine and azithromycin in patients with severe COVID-19 infection. Med. Mal. Infect. 50 (4), 30085-30088. doi: 10.1016/ j.medmal.2020.03.006

Nan, Y., Wu, C., and Zhang, Y.-J. (2018). Interferon independent non-canonical STAT Activation and virus induced inflammation. Viruses 10 (4), 196. doi: 10.3390/v10040196

Neuman, B. W., Kiss, G., Kunding, A. H., Bhella, D., Baksh, M. F., Connelly, S., et al. (2011). A structural analysis of $\mathrm{M}$ protein in coronavirus assembly and morphology. J. Struct. Biol. 174 (1), 11-22. doi: 10.1016/j.jsb.2010.11.021

Nicholls, J. M., Poon, L. L., Lee, K. C., Ng, W. F., Lai, S. T., Leung, C. Y., et al. (2003). Lung pathology of fatal severe acute respiratory syndrome. Lancet 361 (9371), 1773-1778. doi: 10.1016/s0140-6736(03)13413-7

Niu, P., Zhang, S., Zhou, P., Huang, B., Deng, Y., Qin, K., et al. (2018a). Ultrapotent human neutralizing antibody repertoires against Middle East respiratory syndrome coronavirus from a recovered patient. J. Infect. Dis. 218 (8), 1249-1260. doi: 10.1093/infdis/jiy311

Niu, P., Zhao, G., Deng, Y., Sun, S., Wang, W., Zhou, Y., et al. (2018b). A novel human $\mathrm{mAb}$ (MERS-GD27) provides prophylactic and postexposure efficacy in MERS-CoV susceptible mice. Sci. China Life Sci. 61 (10), 1280-1282. doi: 10.1007/s11427-018-9343-8

Okumura, A., Pitha, P. M., Yoshimura, A., and Harty, R. N. (2010). Interaction between Ebola virus glycoprotein and host toll-like receptor 4 leads to induction of proinflammatory cytokines and SOCS1. J. Virol. 84 (1), 27-33. doi: 10.1128/JVI.01462-09

Ortiz-Pérez, J. T., Riera, M., Bosch, X., De Caralt, T. M., Perea, R. J., Pascual, J., et al. (2013). Role of circulating angiotensin converting enzyme 2 in left ventricular remodeling following myocardial infarction: a prospective controlled study. PloS One 8 (4), e61695. doi: 10.1371/journal.pone.0061695

Ou, X., Liu, Y., Lei, X., Li, P., Mi, D., Ren, L., et al. (2020). Characterization of spike glycoprotein of SARS-CoV-2 on virus entry and its immune cross-reactivity with SARS-CoV. Nat. Commun. 11 (1), 1-12. doi: 10.1038/s41467-020-15562-9

Pachetti, M., Marini, B., Benedetti, F., Giudici, F., Mauro, E., Storici, P., et al. (2020). Emerging SARS-CoV-2 mutation hot spots include a novel RNAdependent-RNA polymerase variant. J. Trans. Med. 18, 1-9. doi: 10.1186/ s12967-020-02344-6

Pardi, N., Hogan, M. J., Porter, F. W., and Weissman, D. (2018). mRNA vaccines -a new era in vaccinology. Nat. Rev. Drug Discovery 17 (4), 261. doi: 10.1038/ nrd.2017.243
Patterson, B. K., Seethamraju, H., Dhody, K., Corley, M. J., Kazempour, K., Lalezari, J. P., et al. (2020). Disruption of the CCL5/RANTES-CCR5 Pathway Restores Immune Homeostasis and Reduces Plasma Viral Load in Critical COVID-19. MedRxiv 1-24. doi: 10.1101/2020.05.02.20084673

Peiris, J., Guan, Y., and Yuen, K. (2004). Severe acute respiratory syndrome. Nat. Med. 10 (12), S88-S97. doi: 10.1038/nm1143

Prompetchara, E., Ketloy, C., and Palaga, T. (2020). Immune responses in COVID-19 and potential vaccines: Lessons learned from SARS and MERS epidemic. Asian Pac. J. Allergy Immunol. 38 (1), 1-9. doi: 10.12932/AP200220-0772

Pugach, P., Ketas, T. J., Michael, E., and Moore, J. P. (2008). Neutralizing antibody and anti-retroviral drug sensitivities of HIV-1 isolates resistant to small molecule CCR5 inhibitors. Virology 377 (2), 401-407. doi: 10.1016/ j.virol.2008.04.032

Qu, D., Zheng, B., Yao, X., Guan, Y., Yuan, Z.-H., Zhong, N.-S., et al. (2005). Intranasal immunization with inactivated SARS-CoV (SARS-associated coronavirus) induced local and serum antibodies in mice. Vaccine 23 (7), 924-931. doi: 10.1016/j.vaccine.2004.07.031

Rabi, F. A., Al Zoubi, M. S., Kasasbeh, G. A., Salameh, D. M., and Al-Nasser, A. D. (2020). SARS-CoV-2 and Coronavirus Disease 2019: What We Know So Far. Pathogens 9 (3), 1-14. doi: 10.3390/pathogens9030231

Ragab, D., Salah Eldin, H., Taeimah, M., Khattab, R., and Salem, R. (2020). The COVID-19 Cytokine Storm; What We Know So Far. Front. Immunol. 11, 1446. doi: $10.3389 /$ fimmu.2020.01446

Raj, V. S., Mou, H., Smits, S. L., Dekkers, D. H., Müller, M. A., Dijkman, R., et al. (2013). Dipeptidyl peptidase 4 is a functional receptor for the emerging human coronavirus-EMC. Nature 495 (7440), 251-254. doi: 10.1038/nature12005

Ratia, K., Pegan, S., Takayama, J., Sleeman, K., Coughlin, M., Baliji, S., et al. (2008). A noncovalent class of papain-like protease/deubiquitinase inhibitors blocks SARS virus replication. Proc. Natl. Acad. Sci. 105 (42), 16119-16124. doi: 10.1073/pnas. 0805240105

Richardson, P., Griffin, I., Tucker, C., Smith, D., Oechsle, O., Phelan, A., et al. (2020). Baricitinib as potential treatment for $2019-\mathrm{nCoV}$ acute respiratory disease. Lancet (Lond. Engl.) 395 (10223), e30. doi: 10.1016/S0140-6736(20) 30304-4

Rosendahl Huber, S., van Beek, J., de Jonge, J., Luytjes, W., and van Baarle, D. (2014). T cell responses to viral infections-opportunities for peptide vaccination. Front. Immunol. 5, 171. doi: 10.3389/fimmu.2014.00171

Rossignol, J. F. (2016). Nitazoxanide, a new drug candidate for the treatment of Middle East respiratory syndrome coronavirus. J. Infect. Public Health 9 (3), 227-230. doi: 10.1016/j.jiph.2016.04.001

Rts, S. (2015). Clinical Trials Partnership. Efficacy and safety of RTS, S/AS01 malaria vaccine with or without a booster dose in infants and children in Africa: final results of a phase 3, individually randomised, controlled trial. Lancet 386 (9988), 31-45. doi: 10.1016/S0140-6736(15)60721-8

Russell, C. D., Millar, J. E., and Baillie, J. K. (2020). Clinical evidence does not support corticosteroid treatment for 2019-nCoV lung injury. Lancet 395 (10223), 473-475. doi: 10.1016/S0140-6736(20)30317-2

Saha, A., Sharma, A. R., Bhattacharya, M., Sharma, G., Lee, S.-S., and Chakraborty, C. (2020a). Probable Molecular Mechanism of Remdesivir for the Treatment of COVID-19: Need to Know More. Arch. Med. Res. S0188-4409(20)30699-8. doi: 10.1016/j.arcmed.2020.05.001

Saha, A., Sharma, A. R., Bhattacharya, M., Sharma, G., Lee, S.-S., and Chakraborty, C. (2020b). Tocilizumab: A therapeutic option for the treatment of cytokine storm syndrome in COVID-19. Arch. Med. Res. S0188-4409(20)30782-7. doi: 10.1016/j.arcmed.2020.05.009

Saif, L. J. (1993). Coronavirus immunogens. Vet Microbiol. 37 (3-4), 285-297. doi: 10.1016/0378-1135(93)90030-b

Sallard, E., Lescure, F. X., Yazdanpanah, Y., Mentre, F., and Peiffer-Smadja, N. (2020). Type 1 interferons as a potential treatment against COVID-19. Antiviral Res. 178:104791. doi: 10.1016/j.antiviral.2020.104791

Samuel, C. E. (2001). Antiviral actions of interferons. Clin. Microbiol. Rev. 14 (4), 778-809. doi: 10.1128/CMR.14.4.778-809.2001

Sanjuán, R., Nebot, M. R., Chirico, N., Mansky, L. M., and Belshaw, R. (2010). Viral mutation rates. J. Virol. 84 (19), 9733-9748. doi: 10.1128/JVI.00694-10

Santos, J. R., Curran, A., Navarro-Mercade, J., Ampuero, M. F., Pelaez, P., PérezAlvarez, N., et al. (2019). Simplification of antiretroviral treatment from darunavir/ritonavir monotherapy to darunavir/cobicistat monotherapy: 
effectiveness and safety in routine clinical practice. AIDS Res. Hum. Retroviruses 35 (6), 513-518. doi: 10.1089/aid.2018.0178

Schindler, C., Shuai, K., Prezioso, V. R., and Darnell, J. E. (1992). Interferondependent tyrosine phosphorylation of a latent cytoplasmic transcription factor. Science 257 (5071), 809-813. doi: 10.1126/science.1496401

Schmidt, A., Wolff, M. H., and Weber, O. (2006). Coronaviruses with Special Emphasis on First Insights Concerning SARS (Basel, Switzerland: Birkhäuser Basel).

Schneider, W. M., Chevillotte, M. D., and Rice, C. M. (2014). Interferonstimulated genes: a complex web of host defenses. Annu. Rev. Immunol. 32, 513-545. doi: 10.1146/annurev-immunol-032713-120231

Shakoory, B., Carcillo, J. A., Chatham, W. W., Amdur, R. L., Zhao, H., Dinarello, C. A., et al. (2016). Interleukin-1 receptor blockade is associated with reduced mortality in sepsis patients with features of the macrophage activation syndrome: Re-analysis of a prior Phase III trial. Crit. Care Med. 44 (2), 275. doi: 10.1097/CCM.0000000000001402

Shang, W., Yang, Y., Rao, Y., and Rao, X. (2020). The outbreak of SARS-CoV-2 pneumonia calls for viral vaccines. NPJ Vacc. 5 (1), 1-3. doi: 10.1038/s41541-0200170-0

Sharma, A., Krause, A., and Worgall, S. (2011). Recent developments for Pseudomonas vaccines. Hum. Vacc. 7 (10), 999-1011. doi: 10.4161/ hv.7.10.16369

Shulla, A., Heald-Sargent, T., Subramanya, G., Zhao, J., Perlman, S., and Gallagher, T. (2011). A transmembrane serine protease is linked to the severe acute respiratory syndrome coronavirus receptor and activates virus entry. J. Virol. 85 (2), 873-882. doi: 10.1128/JVI.02062-10

Simmons, G., Reeves, J. D., Rennekamp, A. J., Amberg, S. M., Piefer, A. J., and Bates, P. (2004). Characterization of severe acute respiratory syndrome-associated coronavirus (SARS-CoV) spike glycoprotein-mediated viral entry. Proc. Natl. Acad. Sci. U.S.A. 101 (12), 4240-4245. doi: 10.1073/pnas.0306446101

Sipulwa, L. A., Ongus, J. R., Coldren, R. L., and Bulimo, W. D. (2016). Molecular characterization of human coronaviruses and their circulation dynamics in Keny-2012. Virol. J. 13 (1), 18. doi: 10.1186/s12985-016-0474-x

Smith, T. R., Patel, A., Ramos, S., Elwood, D., Zhu, X., Yan, J., et al. (2020). Immunogenicity of a DNA vaccine candidate for COVID-19. Nat. Commun. 11 (1), 1-13. doi: 10.1038/s41467-020-16505-0

Spiegel, M., Pichlmair, A., Martínez-Sobrido, L., Cros, J., García-Sastre, A., Haller, O., et al. (2005). Inhibition of beta interferon induction by severe acute respiratory syndrome coronavirus suggests a two-step model for activation of interferon regulatory factor 3. J. Virol. 79 (4), 2079-2086. doi: 10.1128/JVI.79.4.20792086.2005

Stanifer, M. L., Pervolaraki, K., and Boulant, S. (2019). Differential regulation of type I and type III interferon signaling. Int. J. Mol. Sci. 20 (6), 1445. doi: $10.3390 /$ ijms 20061445

Steinmetzer, T., and Hardes, K. (2018). "The antiviral potential of host protease inhibitors," in Activation of Viruses by Host Proteases (Cham, Switzerland: Springer), 279-325.

Stockman, L. J., Bellamy, R., and Garner, P. (2006). SARS: systematic review of treatment effects. PloS Med. 3 (9), e343. doi: 10.1371/journal.pmed.0030343

Sui, J., Li, W., Murakami, A., Tamin, A., Matthews, L. J., Wong, S. K., et al. (2004). Potent neutralization of severe acute respiratory syndrome (SARS) coronavirus by a human $\mathrm{mAb}$ to $\mathrm{S} 1$ protein that blocks receptor association. Proc. Natl. Acad. Sci. 101 (8), 2536-2541. doi: 10.1073/pnas.0307140101

Takada, A., and Kawaoka, Y. (2003). Antibody-dependent enhancement of viral infection: molecular mechanisms and in vivo implications. Rev. Med. Virol. 13 (6), 387-398. doi: 10.1002/rmv.405

Takano, T., Yamada, S., Doki, T., and Hohdatsu, T. (2019). Pathogenesis of oral type I feline infectious peritonitis virus (FIPV) infection: Antibody-dependent enhancement infection of cats with type I FIPV via the oral route. J. Vet. Med. Sci. 81 (6), 18-0702. doi: 10.1292/jvms.18-0702

Takeuchi, O., and Akira, S. (2009). Innate immunity to virus infection. Immunol. Rev. 227 (1), 75-86. doi: 10.1111/j.1600-065X.2008.00737.x

Taylor, R., Kotian, P., Warren, T., Panchal, R., Bavari, S., Julander, J., et al. (2016). BCX4430-a broad-spectrum antiviral adenosine nucleoside analog under development for the treatment of Ebola virus disease. J. Infect. Public Health 9 (3), 220-226. doi: 10.1016/j.jiph.2016.04.002

Te-hui, W. C., Wang, S., Sakhatskyy, P. V., Mboudoudjeck, I., Lawrence, J. M., Huang, S., et al. (2005). Epitope mapping and biological function analysis of antibodies produced by immunization of mice with an inactivated Chinese isolate of severe acute respiratory syndrome-associated coronavirus (SARSCoV). Virology 334 (1), 134-143. doi: 10.1016/j.virol.2005.01.035

Totura, A. L., and Baric, R. S. (2012). SARS coronavirus pathogenesis: host innate immune responses and viral antagonism of interferon. Curr. Opin. Virol. 2 (3), 264-275. doi: 10.1016/j.coviro.2012.04.004

Tsai, M.-H., Pai, L.-M., and Lee, C.-K. (2019). Fine-tuning of the type I interferon response by STAT3. Front. Immunol. 10, 1448. doi: 10.3389/fimmu.2019.01448

Uyeki, T. M. (2018). "Oseltamivir treatment of influenza in children" (Arlington, Virginia, United States: Oxford University Press US).

Vangelista, L., and Vento, S. (2018). The expanding therapeutic perspective of CCR5 blockade. Front. Immunol. 8, 1981. doi: 10.3389/fimmu.2017.01981

Venkiteshwaran, A. (2009). Tocilizumab. MAbs 1 (5), 432-438. doi: 10.4161/ mabs.1.5.9497

Villalaín, J. (2010). Membranotropic effects of arbidol, a broad anti-viral molecule, on phospholipid model membranes. J. Phys. Chem. B 114 (25), 8544-8554. doi: $10.1021 /$ jp $102619 \mathrm{w}$

Vincent, M. J., Bergeron, E., Benjannet, S., Erickson, B. R., Rollin, P. E., Ksiazek, T. G., et al. (2005). Chloroquine is a potent inhibitor of SARS coronavirus infection and spread. Virol. J. 2, 69. doi: 10.1186/1743-422X-2-69

Wagstaff, K. M., Sivakumaran, H., Heaton, S. M., Harrich, D., and Jans, D. A. (2012). Ivermectin is a specific inhibitor of importin $\alpha / \beta$-mediated nuclear import able to inhibit replication of HIV-1 and dengue virus. Biochem. J. 443 (3), 851-856. doi: 10.1042/BJ20120150

Walls, A. C., Park, Y.-J., Tortorici, M. A., Wall, A., McGuire, A. T., and Veesler, D. (2020). Structure, function, and antigenicity of the SARS-CoV-2 spike glycoprotein. Cell 181 (2), 281-292.e6. doi: 10.1016/j.cell.2020.02.058

Wan, Y., Shang, J., Graham, R., Baric, R. S., and Li, F. (2020). Receptor recognition by the novel coronavirus from Wuhan: an analysis based on decade-long structural studies of SARS coronavirus. J. Virol. 94 (7), e00127-20. doi: 10.1128/JVI.00127-20

Wang, X., Mathieu, M., and Brezski, R. J. (2018). IgG Fc engineering to modulate antibody effector functions. Protein Cell 9 (1), 63-73. doi: 10.1007/s13238-0170473-8

Wang, C., Horby, P. W., Hayden, F. G., and Gao, G. F. (2020a). A novel coronavirus outbreak of global health concern. Lancet 395 (10223), 470-473. doi: $10.1016 / S 0140-6736(20) 30185-9$

Wang, C., Li, W., Drabek, D., Okba, N. M. A., van Haperen, R., Osterhaus, A. D. M. E., et al. (2020b). A human monoclonal antibody blocking SARSCoV-2 infection. BioRxiv 2020.2003.2011.987958, 1-2. doi: 10.1101/ 2020.03.11.987958

Wang, D., Hu, B., Hu, C., Zhu, F., Liu, X., Zhang, J., et al. (2020). Clinical characteristics of 138 hospitalized patients with 2019 novel coronavirusinfected pneumonia in Wuhan, China. Jama 323 (11), 1061-1069. doi: 10.1001/jama.2020.1585

Wang, M., Cao, R., Zhang, L., Yang, X., Liu, J., Xu, M., et al. (2020). Remdesivir and chloroquine effectively inhibit the recently emerged novel coronaviru$\mathrm{nCoV}$ ) in vitro. Cell Res. 30 (3), 269-271. doi: 10.1038/s41422-020-0282-0

Wang, T., Du, Z., Zhu, F., Cao, Z., An, Y., Gao, Y., et al. (2020). Comorbidities and multi-organ injuries in the treatment of COVID-19. Lancet 395 (10228), e52. doi: 10.1016/S0140-6736(20)30558-4

WHO (2020). WHO Director-General's opening remarks at the media briefing on COVID-19 - 11 March 2020. (Geneva: World Health Organization).

WHO (2003). SARS outbreak contained worldwide. (Geneva: World Health Organization).

Wong, S. K., Li, W., Moore, M. J., Choe, H., and Farzan, M. (2004). A 193-amino acid fragment of the SARS coronavirus S protein efficiently binds angiotensinconverting enzyme 2. J. Biol. Chem. 279 (5), 3197-3201. doi: 10.1074/ jbc.C300520200

World Health Organization (2005). "Statement on the second meeting of the International Health Regulations (2005) Emergency Committee regarding the outbreak of novel coronavirus (2019-nCoV)".

World Health Organization (2019). "MERS situation update, December 2019".

World Health Organization (2020). Naming the coronavirus disease (COVID-19) and the virus that causes it. World Health Organization.

Wrapp, D., Wang, N., Corbett, K. S., Goldsmith, J. A., Hsieh, C.-L., Abiona, O., et al. (2020). Cryo-EM structure of the 2019-nCoV spike in the prefusion conformation. Science 367 (6483), 1260-1263. doi: 10.1126/science.abb2507 
Wu, A., Peng, Y., Huang, B., Ding, X., Wang, X., Niu, P., et al. (2020). Genome composition and divergence of the novel coronavirus $(2019-\mathrm{nCoV})$ originating in China. Cell Host Microbe 27 (3), 0325-328. doi: 10.1016/j.chom.2020.02.001

Wu, C., Liu, Y., Yang, Y., Zhang, P., Zhong, W., Wang, Y., et al. (2020). Analysis of therapeutic targets for SARS-CoV-2 and discovery of potential drugs by computational methods. Acta Pharm. Sin. B 10 (5), 766-788. doi: 10.1016/ j.apsb.2020.02.008

Wu, F., Zhao, S., Yu, B., Chen, Y.-M., Wang, W., Song, Z.-G., et al. (2020). A new coronavirus associated with human respiratory disease in China. Nature 579 (7798), 265-269. doi: 10.1038/s41586-020-2008-3

Xiong, S., Wang, Y.-F., Zhang, M.-Y., Liu, X.-J., Zhang, C.-H., Liu, S.-S., et al. (2004). Immunogenicity of SARS inactivated vaccine in BALB/c mice. Immunol. Lett. 95 (2), 139-143. doi: 10.1016/j.imlet.2004.06.014

Xu, H., Zhong, L., Deng, J., Peng, J., Dan, H., Zeng, X., et al. (2020). High expression of ACE2 receptor of $2019-\mathrm{nCoV}$ on the epithelial cells of oral mucosa. Int. J. Oral. Sci. 12 (1), 1-5. doi: 10.1038/s41368-020-0074-x

Xue, X., Yu, H., Yang, H., Xue, F., Wu, Z., Shen, W., et al. (2008). Structures of two coronavirus main proteases: implications for substrate binding and antiviral drug design. J. Virol. 82 (5), 2515-2527. doi: 10.1128/JVI.02114-07

Yamada, M., Hayashi, H., Yuuki, M., Matsushima, N., Yuan, B., and Takagi, N. (2018). Furin inhibitor protects against neuronal cell death induced by activated NMDA receptors. Sci. Rep. 8 (1), 1-9. doi: 10.1038/s41598-01823567-0

Yamamoto, N., Yang, R., Yoshinaka, Y., Amari, S., Nakano, T., Cinatl, J., et al. (2004). HIV protease inhibitor nelfinavir inhibits replication of SARSassociated coronavirus. Biochem. Biophys. Res. Commun. 318 (3), 719-725. doi: 10.1016/j.bbrc.2004.04.083

Yamamoto, M., Matsuyama, S., Li, X., Takeda, M., Kawaguchi, Y., Inoue, J. I., et al. (2016). Identification of Nafamostat as a Potent Inhibitor of Middle East Respiratory Syndrome Coronavirus S Protein-Mediated Membrane Fusion Using the Split-Protein-Based Cell-Cell Fusion Assay. Antimicrob. Agents Chemother. 60 (11), 6532-6539. doi: 10.1128/AAC.01043-16

Yamey, G., Schäferhoff, M., Hatchett, R., Pate, M., Zhao, F., and McDade, K. K. (2020). Ensuring global access to COVID-19 vaccines. Lancet 395 (10234), 1405-1406. doi: 10.1016/S0140-6736(20)30763-7

Yang, N., and Shen, H.-M. (2020). Targeting the endocytic pathway and autophagy process as a novel therapeutic strategy in COVID-19. Int. J. Biol. Sci. 16 (10), 1724. doi: 10.7150/ijbs.45498

Yang, H., Yang, M., Ding, Y., Liu, Y., Lou, Z., Zhou, Z., et al. (2003). The crystal structures of severe acute respiratory syndrome virus main protease and its complex with an inhibitor. Proc. Natl. Acad. Sci. 100 (23), 13190-13195. doi: 10.1073/pnas.1835675100

Yang, S. N. Y., Atkinson, S. C., Wang, C., Lee, A., Bogoyevitch, M. A., Borg, N. A., et al. (2020). The broad spectrum antiviral ivermectin targets the host nuclear transport importin $\alpha / \beta 1$ heterodimer. Antiviral Res. 177, S0140-6736(20) 31605-6.-104760. doi: 10.1016/j.antiviral.2020.104760

Ye, Q., Wang, B., and Mao, J. (2020). The pathogenesis and treatment of theCytokine Storm'in COVID-19. J. Infect. 80 (6), 607-613. doi: 10.1016/ j.jinf.2020.03.037

Yeager, C. L., Ashmun, R. A., Williams, R. K., Cardellichio, C. B., Shapiro, L. H., Look, A. T., et al. (1992). Human aminopeptidase $\mathrm{N}$ is a receptor for human coronavirus 229E. Nature 357 (6377), 420-422. doi: 10.1038/357420a0

Yu, J., Tostanoski, L. H., Peter, L., Mercado, N. B., McMahan, K., Mahrokhian, S. H., et al. (2020). DNA vaccine protection against SARS-CoV-2 in rhesus macaques. Science. doi: 10.1126/science.abc6284

Yuan, M., Wu, N. C., Zhu, X., Lee, C.-C. D., So, R. T., Lv, H., et al. (2020). A highly conserved cryptic epitope in the receptor-binding domains of SARS-CoV-2 and SARS-CoV. Science 368 (6491), 630-633. doi: 10.1126/science.abb7269
Zanoni, I., Granucci, F., and Broggi, A. (2017). Interferon (IFN)- $\lambda$ takes the helm: immunomodulatory roles of type III IFNs. Front. Immunol. 8, 1661. doi: 10.3389/fimmu.2017.01661

Zhang, M.-Y., Wang, Y., Mankowski, M. K., Ptak, R. G., and Dimitrov, D. S. (2009). Cross-reactive HIV-1-neutralizing activity of serum IgG from a rabbit immunized with gp41 fused to IgG1 Fc: possible role of the prolonged half-life of the immunogen. Vaccine 27 (6), 857-863. doi: 10.1016/j.vaccine.2008.11.083

Zhang, C., Wu, Z., Li, J.-W., Zhao, H., and Wang, G.-Q. (2020). The cytokine release syndrome (CRS) of severe COVID-19 and Interleukin6 receptor (IL-6R) antagonist Tocilizumab may be the key to reduce the mortality. Int. J. Antimicrob. Agents 55 (5), 105954. doi: 10.1016/ j.ijantimicag.2020.105954

Zhang, G., Pomplun, S., Loftis, A. R., Loas, A., and Pentelute, B. L. (2020). The first-in-class peptide binder to the SARS-CoV-2 spike protein. BioRxiv 1-15. 2020.2003.2019.999318. doi: 10.1101/2020.03.19.999318

Zhang, H., Penninger, J. M., Li, Y., Zhong, N., and Slutsky, A. S. (2020a). Angiotensin-converting enzyme 2 (ACE2) as a SARS-CoV-2 receptor: molecular mechanisms and potential therapeutic target. Intensive Care Med. 46 (4), 1-5. doi: 10.1007/s00134-020-05985-9

Zhang, H., Penninger, J. M., Li, Y., Zhong, N., and Slutsky, A. S. (2020b). Angiotensin-converting enzyme 2 (ACE2) as a SARS-CoV-2 receptor: molecular mechanisms and potential therapeutic target. Intensive Care Med. 46 (4), 586-590. doi: 10.1007/s00134-020-05985-9

Zhang, J., Zeng, H., Gu, J., Li, H., Zheng, L., and Zou, Q. (2020). Progress and Prospects on Vaccine Development against SARS-CoV-2. Vaccines 8 (2), 153. doi: $10.3390 /$ vaccines 8020153

Zhang, J. N., Wang, W. J., Peng, B., Peng, W., Zhang, Y. S., Wang, Y. L., et al. (2020). Potential of Arbidol for Post-exposure Prophylaxis of COVID-19 Transmission: A Preliminary Report of a Retrospective Cohort Study. Curr. Med. Sci. 40 (3), 480-485. doi: 10.1007/s11596-020-2203-3

Zhang, L., Lin, D., Sun, X., Curth, U., Drosten, C., Sauerhering, L., et al. (2020). Crystal structure of SARS-CoV-2 main protease provides a basis for design of improved $\alpha$-ketoamide inhibitors. Science 368 (6489), 409-412. doi: 10.1126/ science.abb3405

Zhou, P., Yang, X.-L., Wang, X.-G., Hu, B., Zhang, L., Zhang, W., et al. (2020). A pneumonia outbreak associated with a new coronavirus of probable bat origin. Nature 579 (7798), 270-273. doi: 10.1038/s41586-020-2012-7

Zhu, F.-C., Guan, X.-H., Li, Y.-H., Huang, J.-Y., Jiang, T., Hou, L.-H., et al. (2020). Immunogenicity and safety of a recombinant adenovirus type-5-vectored COVID-19 vaccine in healthy adults aged 18 years or older: a randomised, double-blind, placebo-controlled, phase 2 trial. Lancet S0140-6736(20)316056. doi: 10.1016/S0140-6736(20)31605-6

Zu, Z. Y., Jiang, M. D., Xu, P. P., Chen, W., Ni, Q. Q., Lu, G. M., et al. (2020). Coronavirus disease 2019 (COVID-19): a perspective from China. Radiology 296 (2), 200490. doi: 10.1148/radiol.2020200490

Conflict of Interest: The authors declare that the research was conducted in the absence of any commercial or financial relationships that could be construed as a potential conflict of interest.

Copyright (C) 2020 Saha, Sharma, Singh, Samanta, Bhakta, Mandal, Bhattacharya, Lee and Chakraborty. This is an open-access article distributed under the terms of the Creative Commons Attribution License (CC BY). The use, distribution or reproduction in other forums is permitted, provided the original author(s) and the copyright owner(s) are credited and that the original publication in this journal is cited, in accordance with accepted academic practice. No use, distribution or reproduction is permitted which does not comply with these terms. 